UNIVERSIDADE DE BRASÍLIA

FACULDADE DE TECNOLOGIA

DEPARTAMENTO DE ENGENHARIA MECÂNICA

\title{
AVALIAÇÃO DO PASSE DE RAIZ EM JUNTA \\ DE CHANFRO ESTREITO NA SOLDAGEM ORBITAL PELO PROCESSO GMAW CMT E CONVENCIONAL
}

\author{
HERLYS HERNANDO CANIZAREZ TORRES
}

Orientador: Sadek Crisóstomo Absí Alfaro

Universidade de Brasília

DISSERTAÇÃO DE MESTRADO EM SISTEMAS MECATRÔNICOS

Publicação: ENM.DM - 99/2016

BRASÍLIA-DF, 25 de Maio de 2016 
UNIVERSIDADE DE BRASÍLIA

FACULDADE DE TECNOLOGIA

DEPARTAMENTO DE ENGENHARIA MECÂNICA

\title{
AVALIAÇÃO DO PASSE DE RAIZ EM JUNTA DE CHANFRO ESTREITO NA SOLDAGEM ORBITAL PELO PROCESSO GMAW CMT E CONVENCIONAL
}

\author{
HERLYS HERNANDO CANIZAREZ TORRES
}

DISSERTAÇÃO DE MESTRADO SUBMETIDA AO DEPARTAMENTO DE ENGENHARIA MECÂNICA DA FACULDADE DE TECNOLOGIA DA UNIVERSIDADE DE BRASÍLIA COMO REQUISITO PARCIAL PARA A OBTENÇÃO DO GRAU DE MESTRE EM SISTEMAS MECATRÔNICOS.

Banca Examinadora

Prof. Sadek Crisóstomo Absí Alfaro, phD. (ENM-UnB)

(Orientador)

Prof. Alexandre Queiroz Bracarense, phD. (EM-UFMG)

(Examinador Externo)

Prof. Guilherme Caribé de Carvalho, phD. (ENM-UnB)

(Examinadora Interno)

Prof. Jose Enrique Vargas Aures, phD. (ENM-UnB)

(Examinador Suplente)

BRASÍLIA-DF, 25 de Maio de 2016 


\section{FICHA CATALOGRÁFICA}

\section{HERLYS HERNANDO CANIZAREZ TOREES}

Avaliação do passe de raiz em junta de chanfro estreito na soldagem orbital pelo processo GMAW CMT e Convencional [Distrito Federal] 2016.

xiv, 110p. $210 \times 297$ mm (ENM/FT/UnB, Mestre, Sistemas Mecatrônicos, 2015). Dissertação de Mestrado - Universidade de Brasília. Faculdade de Tecnologia.

Departamento de Engenharia Mecânica.

1. Soldagem GMAW derivativo

3. Passe de Raiz

I. $\mathrm{ENM} / \mathrm{FT} / \mathrm{UnB}$
2. Soldagem Orbital

4. Planejamento Experimental

II. Título (série)

\section{REFERÊNCIA BIBLIOGRÁFICA}

TORRES, HERLYS HERNANDO CANIZAREZ. (2016). Avaliação do passe de raiz em junta de chanfro estreito na soldagem orbital pelo processo GMAW CMT e Convencional. Dissertação de Mestrado em Sistemas Mecatrônicos, Publicação ENM.DM-99/2016, Departamento de Engenharia Mecânica, Universidade de Brasília, Brasília, DF, 110p.

\section{CESSÃO DE DIREITOS}

AUTOR: HERLYS HERNANDO CANIZAREZ TORRES.

TÍTULO: AVALIAÇÃO DO PASSE DE RAIZ EM JUNTA DE CHANFRO ESTREITO NA SOLDAGEM ORBITAL PELO PROCESSO GMAW CMT E CONVENCIONAL.

GRAU: Mestre

ANO: 2016

É concedida à Universidade de Brasília permissão para reproduzir cópias desta dissertação de mestrado e para emprestar ou vender tais cópias somente para propósitos acadêmicos e científicos. O autor reserva outros direitos de publicação e nenhuma parte dessa dissertação de mestrado pode ser reproduzida sem autorização por escrito do autor.

Herlys Hernando Canizarez Torres

Campus Universitário Darcy Ribeiro Colina bloco K, Apartamento 105

70904-111 Brasília-DF-Brasil 
Dedicatória

À Maribel;

À minha mãe querida;

Às minhas irmãs e os meus irmãos.

HERLYS HERNANDO CANIZAREZ TORRES 


\section{Agradecimentos}

Agradeço primeiramente a Deus sobre todas as coisas, pela proteção e bênções recebidas. Por ter me dado condições de lutar e alcançar os objetivos pretendidos.

Ao meu orientador, professor Sadek Crisóstomo, pela amizade, orientação, apoio e confiança na realização deste trabalho. Por ter me permitido trabalhar ao seu lado, aprendendo um pouco mais a cada dia.

Para a minha família, por que mesmo de longe sempre estiveram do meu lado o tempo todo, me apoiando e dando forças nos momentos difíceis nesta etapa. Meus pais: Hugo Hernando e Maribel. Irmãos: Blanca, Yulieth, Andres, Alexander, Jaider, carlitos e meus manitos ocañeros: Hugo, Maira e Juan Pablo. E com carinho especial para Nasly e Cindy por sempre estar dispostas a me escutar e apoiar, para todos eles meu maior agradecimento.

A uma pessoa sem aparecer, na etapa final trouxestes sol para minha vida e luz para o meu caminho, se eu me perder na estrada sei que não estarei sozinho. Você é minha Rosa!.

Ao programa da Pós-graduação Sistemas Mecatrônicos da Faculdade de Tecnologia da UnB, e ao professor Carlos Llanos pela disposição brindada.

Ao GRACO laboratório onde há muitos amigos: Oscar, Margarita, Wendy, Maira, Jesus, Andres, Edinson, Rodrigo, Lazaro, Manuel, Sebastian, Sergio, Edgar, sob a vigia do MARROCOS grande servidor, e onde cada um deles é tão importante quanto o outro. Também ao pessoal da oficina do bloco SG-9, bons amigos: Arthur, Pereira, Xavier, Tharsis, Marcão, Miguel. Meus agradecimentos a todos eles.

Ao Laboratório de Robótica, Soldagem e Simulação (LRSS), um grupo de pessoas com muito potencial, sempre trabalhando. A Luciano pela amizade e ajuda desde a minha chegada a este laboratório, um bom amigo. Aos alunos de IC: Higor e Pedro, o Eustáquio pela ajuda no desenvolvimento e realização do trabalho, Também aos colegas de pós-graduação: Ariel, Renata, Aline, Oscar, Juan, Carlos, Ricardo, todos eles que de uma forma ou de outra fizeram que eu me sentisse em casa, o Professor Ramón. E Finalmente ao apoio e disposição ao Professor Alexandre quem permitiu fazer a fase final de meu trabalho de mestrado no laboratório.

A meus amigos do apto 105 da colina foram uma família na estadia: Eder, Luis, José, Aramis, Rodolfo, Mayco, Nicolas, Joao e a linda Claudia.

E finalmente ao Coordenação de Aperfeiçoamento de Pessoal de Nível Superior (CAPES), pelo apoio financeiro.

HERLYS HERNANDO CANIZAREZ TORRES 
“...Escribe las cosas de tu vida a lápiz así podrás borrar y hacer más, ella es como una leyenda, no importa qué tan larga sea sino que tan bien quede narrada..." “...Escreva as coisas de sua vida a lápis para que possa apagar e fazer mais, ela é como uma lenda, não importa quanto tempo precise, sem não que ela seja bem contada... ".

Juan Arturo San Juan Sanguino (Una noche de conmemoración) 


\section{RESUMO}

Neste trabalho se apresenta uma metodologia para união de tubos pelo processo de soldagem com a deposição do passe de raiz. Na realização da soldagem de topo, externa e sem abertura de raiz, a altura da face de raiz é um fator fundamental para obter penetração total. Em alguns casos, mata-juntas (podem ser de cobre o de materiais cerâmicos) são usadas para evitar vazamentos de solda. Porém, o cobre pode ocasionar inclusões e corrosão, além de trazer muitas dificuldades no momento de instalação e gerar grandes custos em campo. Assim sendo, realizouse uma análise do efeito da penetração utilizando-se o método de fase de nariz decrescente na soldagem de passe de raiz sem uso de cobre-junta nem abertura de raiz, para as seguintes posições críticas de soldagem: plana, vertical e sobrecabeça. A análise foi feita utilizando o processo de soldagem MIG/MAG por curto-circuito derivativo, GMAW-CMT (Gas Metal Arc Welding Cold Metal Transfer), com arame AWS ER 70S-6 (1,2mm) e o gás de proteção Ar+25\%CO . O Planejamento Composto Central foi utilizado como ferramenta para a melhor organização dos testes e para análise dos resultados fez-se uma otimização utilizando a teoria de Desirability para múltiplas respostas, usando chapas planas de aço 1020 com chanfro estreito em U. Logo, validase esta metodologia de penetração completa em soldagem orbital de meia volta descendente em um tubo ASTM 106 por meio do processo de soldagem curto-circuito convencional com a ajuda da potência de soldagem mesurada. Os testes foram realizados com arames consumíveis de diâmetros 0,9 e 1,2 mm. Ensaios de macrografia mostraram os passes de raiz com bom aspecto visual e sem defeitos internos, sugerindo assim a possibilidade de execução da soldagem com penetração total.

Palavras-chaves: Soldagem Orbital, Passe de raiz, Chanfro estreito, Planejamento Experimental. 


\begin{abstract}
In this manuscript is presented a methodology to realize the pipe union by the welding process with the deposition of the root pass. In the butt welding execution external without open root, the height of the root face is a key factor for getting full penetration. Sometimes, copper-joints are used to prevent leaks. Though, copper can cause inclusions and corrosion, producing many troubles during the installation and generating large costs in the work area. Therefore, it was performed a penetration effect analysis using the slanted nose phase, method in root pass welding without the use of copper-joint or root opening, for the following critical welding positions: flat, vertical and overhead. The analysis was performed using the welding process MIG/MAG by derivative short circuit, GMAW-CMT (Gas Metal Arc Welding - Cold Metal Transfer), with AWS ER 70S-6 wires $(1.2 \mathrm{~mm})$ a with $\mathrm{Ar}+25 \% \mathrm{CO}_{2}$, as shielding gas. The Central Composite Design (CCD) was used as a tool for a better organization of the tests, whereas to analyze the results it was made an optimization based on the Desirability theory for multiple responses, employing flat sheets of 1020 steel with a narrow-gap in U-shape. Then, this full penetration methodology in orbital welding turned down was validated in a ASTM 106 pipe through the conventional short-circuit welding process, with the joint established in the previous stages. The tests were performed with wires of 0.9 and $1.2 \mathrm{~mm}$ in order to evaluate the welding power. Macrography tests showed root pass with an acceptable visual appearance and without internal defects, thereby suggesting the possibility of welding execution with full penetration.
\end{abstract}

Key Word: Weld Orbital, Root pass, Narrow-gap, Experimental Planning. 


\section{Sumário}

Lista de Figuras $\ldots \ldots \ldots \ldots \ldots \ldots \ldots \ldots \ldots \ldots \ldots \ldots \ldots \ldots \ldots \ldots \ldots \ldots \ldots \ldots \ldots \ldots \ldots$

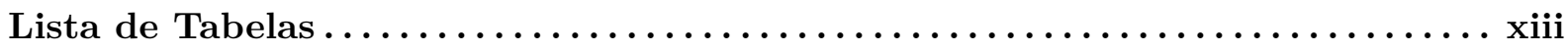

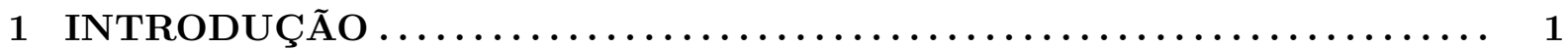

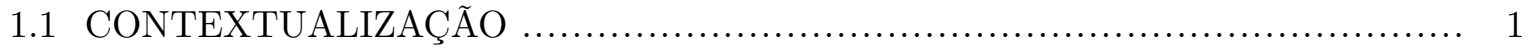

1.2 DEFINIÇÃO DO PROBLEMA E MOTIVAÇÕES ……............................. 3

1.3 OBJETIVOS

1.3.1 Objetivo Geral …...................................................... 5

1.3.2 Objetivos Específicos ……................................................. 5

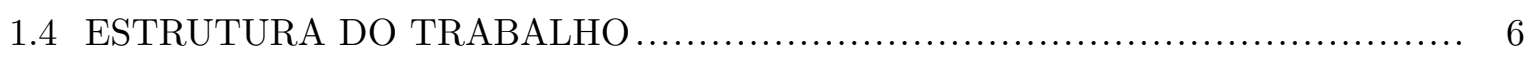

2 REVISÃO BIBLIOGRÁFICA $\ldots \ldots \ldots \ldots \ldots \ldots \ldots \ldots \ldots \ldots \ldots \ldots \ldots \ldots \ldots \ldots \ldots, \mathbf{9}$

2.1 PROCESSO DE SOLDAGEM GMAW ……

2.1.1 Processo GMAW Convencional .............................................. 10

2.1.1.1 Parâmetros de regulagem............................................... 11

2.1.2 Soldagem Por Curto-Circuito Controlado ....................................... 12

2.1.2.1 Processo GMAW-CMT ............................................. 13

2.1.2.2 Parâmetros de regulagem............................................... 16

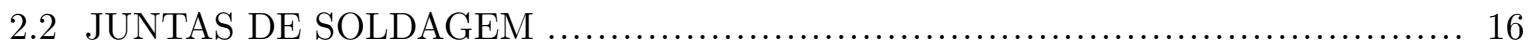

2.2.1 Juntas de Chanfro Estreito ................................................... 18

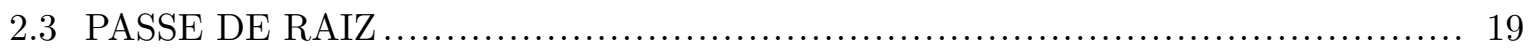

2.3.1 Descontinuidades Apresentadas em Passe de Raiz ............................... 22

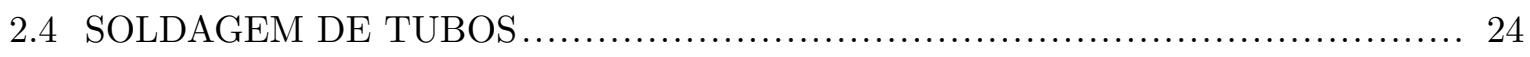

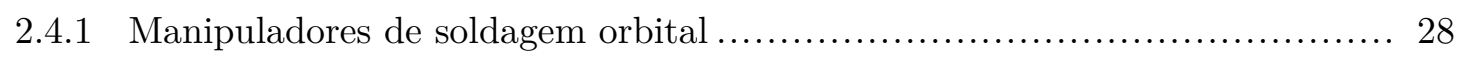

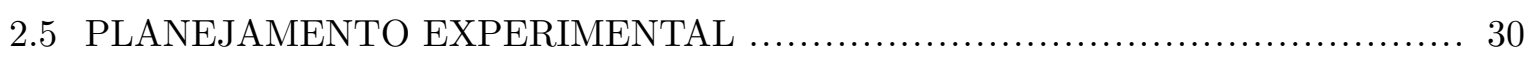

2.5.1 Metodologia de Superfície de Resposta ....................................... 31

2.5.2 Arranjo Composto Central...................................................... 32

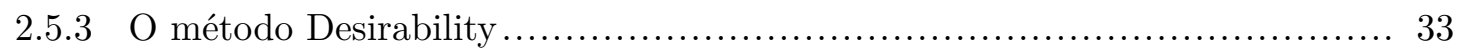

2.6 CÁLCULO DA POTÊNCIA DE SOLDAGEM......................................... 36 


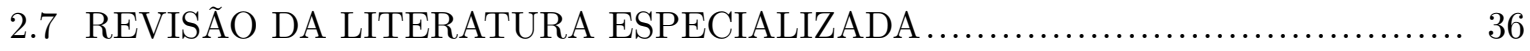

2.7.1 Pesquisas Desenvolvidas por Metodologias Experimentais .................... 36

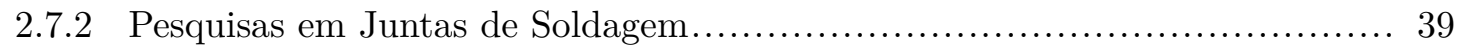

2.7.3 Pesquisas em Juntas de Chanfro Estreito ................................. 40

2.7.4 Pesquisas em Soldagem Orbital............................................. 42

3 METODOLOGIA EXPERIMENTAL $\ldots \ldots \ldots \ldots \ldots \ldots \ldots \ldots \ldots \ldots \ldots \ldots$

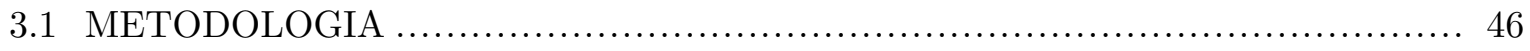

3.1.1 $1^{a}$ Etapa: desenvolvimento de estrutura para diferentes posições e ensaios preliminares ............................................................ 46

3.1.2 $2^{a}$ Etapa: determinação da espessura de nariz para obter penetração completa em três posições críticas de soldagem............................... 51

3.1.2.1 Metodologia de Chanfro com nariz Decrescente .................... 51

3.1.2.2 Construção das juntas de chanfro estreito em "U" .................. 55

3.1.2.3 Planejamento experimental. .................................. 57

3.1.3 $\quad 3^{a}$ Etapa: soldagem circunferencial em Tubo ….......................... 57

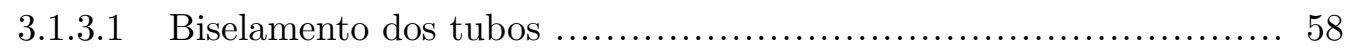

3.1.3.2 Montagem e disposição do equipamento de soldagem............... 60

3.1.3.3 Execução da soldagem Orbital .................................. 61

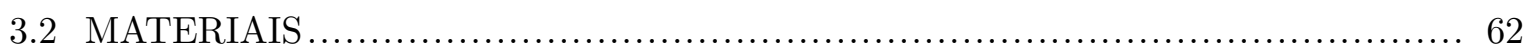

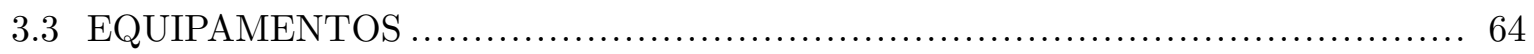

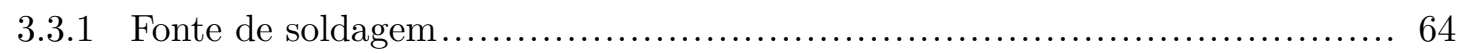

3.3.2 Sistema de translação da tocha ........................................... 65

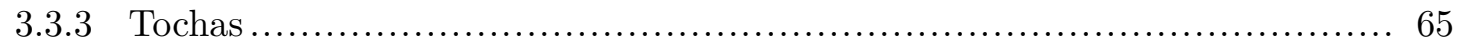

3.3.4 Sistema de aquisição de dados para monitoramento dos sinais elétricos ...... 66

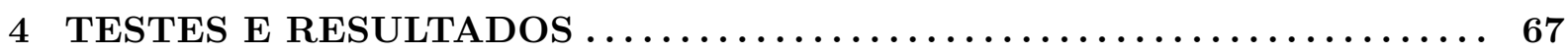

4.1 Resultados da $1^{a}$ etapa - Ensaios preliminares................................... 67

4.2 Resultados da $2^{a}$ etapa - Determinação da espessura de nariz para obter penetração completa em três posições críticas de soldagem................................... 70

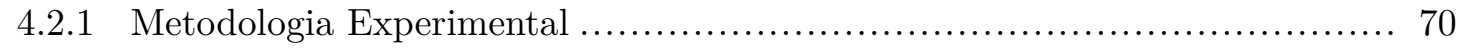

4.2.2 Realização dos Testes...................................................... 71

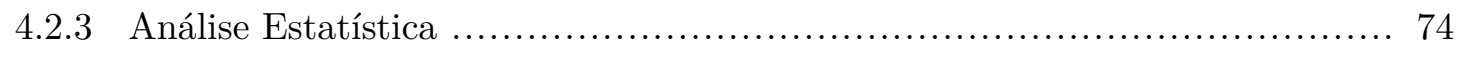

4.2.4 Validação da Otimização Desirability ....................................... 79

4.3 Resultados da $3^{a}$ etapa - Validação da soldagem Orbital ............................ 81

4.3.1 Teste com arame de $0,9 \mathrm{~mm}$ de diâmetro ............................... 81

4.3.2 Teste com arame de $1,2 \mathrm{~mm}$ de diâmetro .................................. 84

4.4 Cálculo da potência de soldagem e discussão dos processos utilizados................ 87 
5 CONCLUSÕES E TRABAlHOS FUtUROS $\ldots \ldots \ldots \ldots \ldots \ldots \ldots \ldots \ldots \ldots .90$

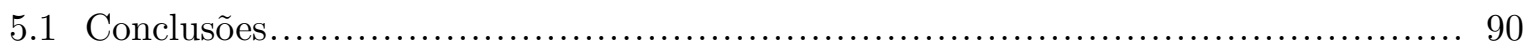

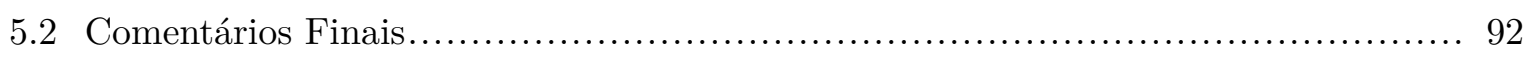

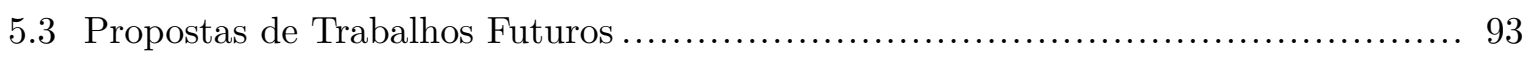

REFERÊNCIAS BIBLIOGRÁFICAS ........................ 94

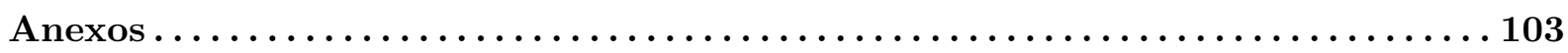

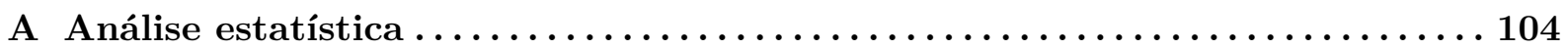

A.1 Avaliação da variância e modelo matemático........................................ 104 


\section{Lista de Figuras}

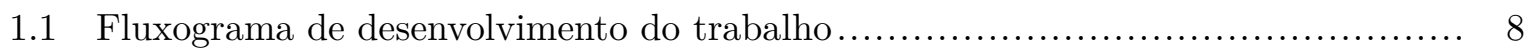

2.1 Componentes intervenientes no processo de soldagem GMAW $[16] \ldots \ldots \ldots \ldots \ldots \ldots \ldots$

2.2 Curso da transferência metálica por curto-circuito no processo GMAW convenci-

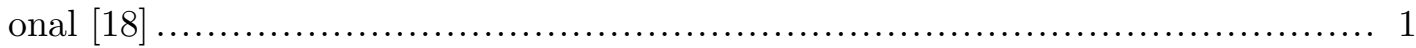

2.3 Oscilograma de tensão e corrente de soldagem em função do ciclo de transferência da gota para o processo CMT (Modificado de Costa [3])......................... 13

2.4 Montagem esquemática do processo CMT robotizado. Em detalhe: (a) Pulmão ou compensador de arame; (b) Alimentador dianteiro.(Adaptado de Fronius [26]).. 15

2.5 Esquema da corrente de transição para as transferências por curto-circuito convencional, curto-circuito controlado (CMT), pulsado, goticular (spray) e rotacio-

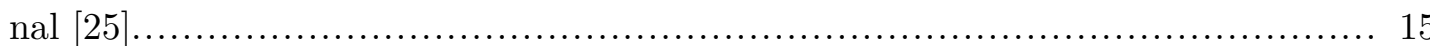

2.6 (a)Tipos de Juntas e (b)Penetração total e parcial [31] ............................ 17

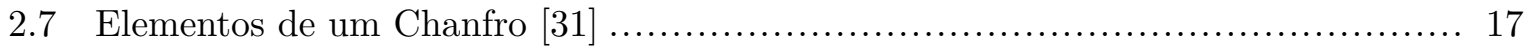

2.8 Diferença entre as áreas a serem preenchidas considerando chanfro estreito e cha-

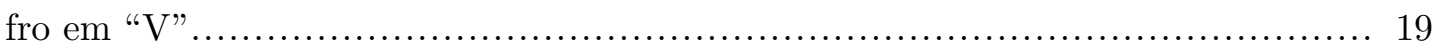

2.9 (a) Junta de Topo em "V" básica com cobre-junta, (b), (c) e (d) juntas de Topo

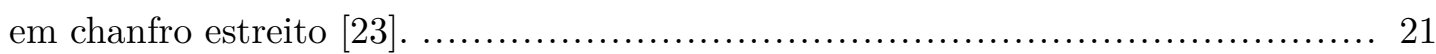

2.10 Espessura de solda em passe de raiz, modificado Barbosa [43] ..................... 21

2.11 Representação da forma prática para obter penetração em junta de topo sem abertura de raiz, modificando: (a) parâmetros de soldagem e (b) espessura do

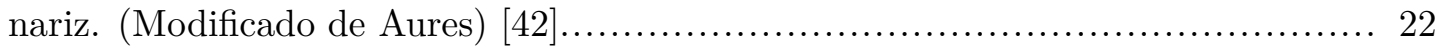

2.12 Soldagem Orbital: (a) Manual, (b) Mecanizada [54] .............................. 25

2.13 Posicionamento dos tubos para realização da soldagem circunferencial (Modifi-

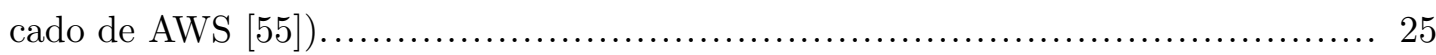

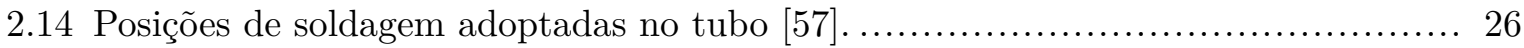

2.15 Representação de uma soldagem na progressão descendente mostrando o posicio-

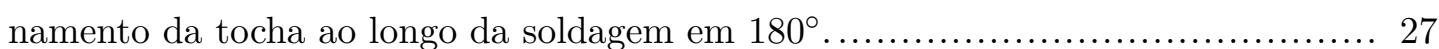

2.16 Tocha de soldagem com os graus de liberdade (Modificado de Filho) [58] ........... 27 
2.17 (a) Orbital FCAW para soldagem de tubos de grande diâmetro [65] , (b) Cabeçotes para soldagem orbital automatizada com duas tochas [66], (c) equipamento

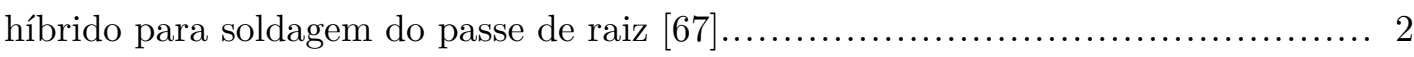

2.18 (a)Suporte de dutos e Tartilope V4 para testes de soldagem orbital [69], (b)Robô de soldagem utilizado em união de tubos [57] ................................... 30

$2.19 C C D$ para três fatores ............................................................. 33

3.1 Posicionamento da tocha nas posições críticas da soldagem circunferencial. ......... 47

3.2 Suporte para fixação e posicionamento de placas de teste. ......................... 48

3.3 Detalhe da mesa junto com os seus componentes. .................................. 48

3.4 Suporte com a mesa e chapas de teste posicionadas para a soldagem (a) plana, (b) vertical e (c) sobrecabeça. 49

3.5 Esquema da chapa para testes preliminares. .................................. 50

3.6 Medidas da chapa com a metodologia de nariz decrescente....................... 52

3.7 Nariz variável ao longo do comprimento do metal de base.......................... 53

3.8 Linhas riscadas na parte inferior da junta, mostrando a espessura de nariz nesses pontos.

3.9 Disposição final da junta com a altura do nariz variável, com valores de: (a) 4 $\mathrm{mm}$ e (b) $0 \mathrm{~mm}$.

3.10 (a) Ponto de início da solda apresentando uma penetração conseguida com uma determinada energia, (b) ponto de penetração total onde o tamanho "h" é a espessura de nariz encontrada para essas condições (c) posição final da tocha.

3.11 Disposição das chapas de teste com a superfície do "nariz decrescente" perpendicular ao deslocamento da tocha nas 3 posições (a)plana, (b)vertical, (c)sobrecabeça. 55

3.12 (a)Formato da ferramenta de aço rápido utilizada na fabricação da junta, (b)Construção da junta.

3.13 Configuração final da junta onde " $\mathrm{h}$ " é o valor de nariz encontrado, para validar a metodologia de chanfro con nariz decrescente nas 3 posições e logo na soldagem orbital

3.14 Dimensões do duto utilizado para soldagem.

3.15 Seção ou anel do tubo durante o processo de usinagem de uniformização do diâmetro interno

3.16 Posição da ferramenta no ponto final da construção do formato da junta no tubo. . 59

3.17 Configuração final de tubos internamente prontos para soldagem com os pontos de fixação. ....................................................................... 60

3.18 Formato final da junta nos tubos........................................... 60

3.19 Sistema de fixação de tubos para soldagem orbital. ................................. 61 
3.20 Desenho do corte transversal do tubo mostrando os pontos para extração dos corpos de prova para análise de macrografia................................... 62

3.21 (a)Fonte Fronius, (b)Robô de Soldagem ABB Robotics. ........................... 64

3.22 (a)Fonte de soldagem, (b)alimentador de arame................................. 65

3.23 Tocha Robacta Drive CMT da Fronius. ........................................ 66

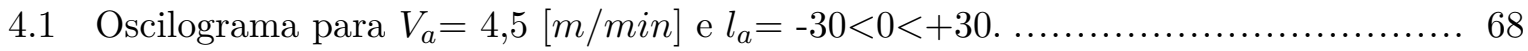

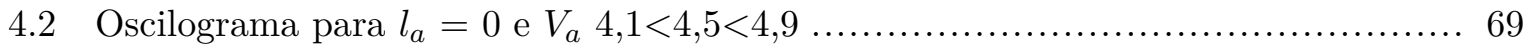

4.3 Teste com desvio do cordão em uma das paredes laterais........................... 72

4.4 Representação de um cordão de solda desviado e sem penetração .................... 72

4.5 Teste de soldagem em posição plana com $V_{a}=4,1(\mathrm{~m} / \mathrm{min}), V_{s}=5,5(\mathrm{~mm} / \mathrm{s})$, $l_{a}=+16$. (a)face, (b)raiz.

4.6 Teste de soldagem em posição vertical com $V_{a}=4,5(\mathrm{~m} / \mathrm{min}), V_{s}=5,75(\mathrm{~mm} / \mathrm{s})$, $l_{a}=0$. (a)fase, (b)raiz.

4.7 Teste de soldagem em posição sobrecabeça com $V_{a}=4,9(\mathrm{~m} / \mathrm{min}), V_{s}=4,5(\mathrm{~mm} / \mathrm{s})$,

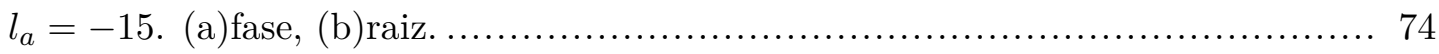

4.8 Probabilidade normal VS Resíduos para penetração em posição plana............... 75

4.9 Superfície de resposta para o modelo de penetração em posição plana............... 75

4.10 Probabilidade normal VS Resíduos para penetração em posição vertical. ............ 76

4.11 Superfície de resposta para o modelo de penetração em posição Vertical. ............ 76

4.12 Probabilidade normal VS Resíduos para penetração em posição Sobrecabeça........ 77

4.13 Superfície de resposta para o modelo de penetração em posição Sobrecabeça. ....... 77

4.14 Individualização de otimização Desirability .......................................... 79

4.15 Aspectos (a) da face e (b) da raiz dos cordões de solda obtidos em juntas de chanfro estreito no processo de simulação com nariz de $2,3 \mathrm{~mm}$, sem cobre-junta... 80

4.16 Seção transversal do cordão, realizado com o processo de validação em junta sem cobre-junta, em pontos onde se encontram as posições CP, CV e CSC, com GMAW-CMT

4.17 Soldagem orbital com arame de 0,9 mm de diâmetro e com parâmetros de otimização Desirability

4.18 (a) Simulação do chanfro com cordões sobrepostos, (b) aspecto visual do cordão depositado na simulação do chanfro para um arame de $0,9 \mathrm{~mm}$ de diâmetro........

4.19 (a)Formato da face do cordão obtido no processo de soldagem orbital com arame de $0,9 \mathrm{~mm}$ de diâmetro, sem cobre-junta, com espessura de nariz de 2,3 $\mathrm{mm}$, para o processo curto-circuito convencional),(b)face, (c)raiz. 
4.20 Seção transversal da soldagem orbital, com o curto-circuito convencional com arame de 0,9 mm de diâmetro, em pontos onde as posições são plana, vertical e sobrecabeça.

4.21 (a) Simulação do chanfro com cordões sobrepostos, (b) aspecto visual do cordão depositado na simulação do chanfro para um arame de 1,2 $\mathrm{mm}$ de diâmetro

4.22 (a)Formato da face do cordão obtido no processo de soldagem orbital com arame de 1,2 mm de diâmetro, sem cobre-junta, com espessura de nariz de 2,3 $\mathrm{mm}$, para o processo curto-circuito convencional), (b)face, (c)raiz.

4.23 Seção transversal da soldagem orbital, com o curto-circuito convencional com arame de 1,2 mm de diâmetro, em pontos onde as posições são plana, vertical e sobrecabeça....

4.24 Oscilogramas de Corrente, tensão para o modo GMAW-CMT aplicado em chapas planas em passe de raiz.

4.25 Oscilogramas de corrente e voltagem, para o modo curto-circuito convencional, com a comparação de dois tipos de arames em passe de raiz aplicada a união de dois tubos com chanfro estreito sem cobre-junta.

4.26 Comparação da potência gerada com o processo GMAW-CMT e curto-circuito convencional utilizado em passe de raiz em juntas de chanfro estreito 


\section{Lista de Tabelas}

2.1 Descontinuidades usualmente apresentadas em passe de raiz [45] [46]. . ............. 23

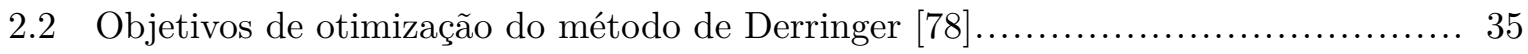

3.1 Níveis y faixas dos Parâmetros de soldagem selecionados para Desenho Composto

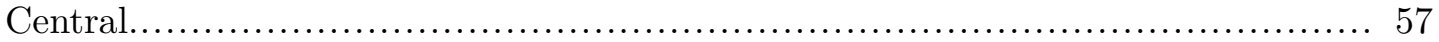

3.2 Composição química (\% em peso) do metal base.................................... 63

3.3 Composição química e propriedades mecânicas do eletrodo …....................... 63

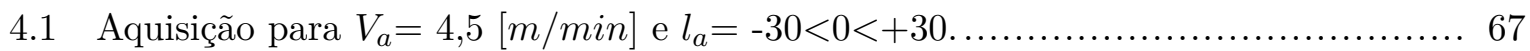

4.2 Seção transversal dos cordões de solda obtidos nesta etapa $\ldots \ldots \ldots \ldots \ldots \ldots \ldots \ldots \ldots \ldots \ldots$

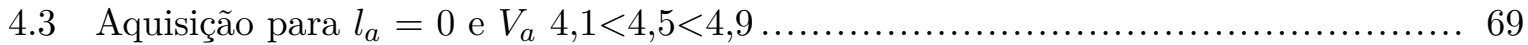

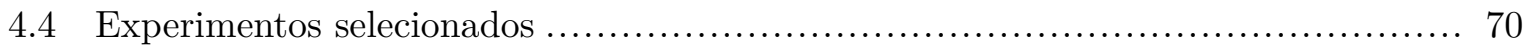

4.5 Resultado dos experimentos do Desenho Central Composto ....................... 71

4.6 Valor alvo especificado dos parâmetros do processo GMAW-CMT com Chanfro

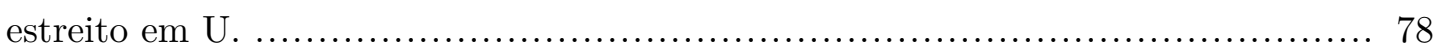

4.7 Resultados dos fatores experimentais para obter penetração completa nas posições críticas de soldagem estabelecidas. .............................................. 78

4.8 Parâmetros para soldagem de tubos com o processo curto-circuito convencional com arame de 0,9 $\mathrm{mm}$ de diâmetro para Passe de raiz

4.9 Parâmetros para soldagem orbital com o processo curto-circuito convencional com arame de $1,2 \mathrm{~mm}$ de diâmetro para Passe de raiz.................................. 85

4.10 Mensuração de valores de Tensão, Corrente (meia e eficaz) e cálculo de Potência... 89 


\section{LISTA DE SÍMBOLOS}

$\begin{array}{ll}\alpha & \text { Ângulo de abertura da junta } \\ C C C & \text { Curto-circuito Controlado } \\ C M T & \text { Cold Metal Transfer } \\ E R & \text { Eletrodo Revestido } \\ f & \text { Abertura, menor distância entre as peças a soldar } \\ F a & \text { Força de arraste } \\ F C A W & \text { Flux Cored Arc Welding } \\ F e m & \text { Força Eletromagnética } \\ F_{g} & \text { Força peso } \\ F_{v} & \text { Força de vaporização } \\ F_{\gamma} & \text { Força Devido a Tensão superficial } \\ G M A W & \text { Gas Metal Arc Welding } \\ G T A W & \text { Gas Tungsten Arc Welding } \\ H L A W & \text { Hybrid Laser Arc Welding } \\ K & \text { Grau Kelvin } \\ M I G & \text { Metal Inert Gas } \\ M I G / M A G & \text { Metal Inert Gas/Metal Active Gas } \\ S & \text { Parte não chanfrada de um componente da junta } \\ S M A W & \text { Shielded Metal Arc Welding } \\ S T T & \text { Surface Tension Transfer } \\ T I G & \text { Tungsten Inert Gas } \\ W E R C & \text { Welding Engineering Center } \\ \beta & \text { Ângulo de chanfro } \\ & \end{array}$




\section{INTRODUÇÃO}

\subsection{CONTEXTUALIZAÇÃO}

O setor de soldagem é um contínuo alvo de investimentos tecnológicos, voltados para a segurança, meio ambiente e para a redução dos custos, com a obtenção de ganho em produção e qualidade. Nisso se dá a necessidade de buscar novas tecnologias de soldagem, tais como novos processos, materiais e fabricação, o que demanda maior conhecimento profissional. Assim o principal desafio que o setor enfrenta é a qualificação de pessoal (soldadores, operários, inspetores, entre outros), tornando o setor apto a absorver, com rapidez, estas novas tecnologias, que estão relacionadas principalmente com desenvolvimento de novas fontes de soldagem com controle eletrônico do processo [1].

Porém, novas abordagens foram introduzidas nos últimos 10 anos, utilizando novos sistemas de controle. As fontes de alimentação atuais (de controle na corrente) são capazes de gerar e manter com mais exatidão e precisão estes novos formatos, com melhoria substancial no controle do arco. Na verdade, a nova geração de fontes fornece um controle mais preciso da transferência de metal com grandes benefícios para a estabilidade do arco [2]. Assim, o entendimento da influência destes parâmetros sobre a qualidade da união soldada é fundamental, porém entender as vantagens e limitações de cada abordagem adotada pelos fabricantes para a linha de desenvolvimento tecnológico (controle do formato de onda e/ou alteração da dinâmica de alimentação do arame) [3].

Estas fontes são empregadas em processos modernos e inovadores como os processos derivativos, os quais exigem um grande número de parâmetros interdependentes a serem ajustados e são também, uma resposta à necessidade contínua do aumento da produtividade e desenvolvimento de novos materiais. Os processos que trabalham em modo de transferência por curto-circuito sobressaem por serem amplamente utilizados e possibilitarem a soldagem fora de posição. A soldagem MIG/MAG (Metal Inert Gas/Metal Active Gas) destaca-se pelo seu largo uso industrial. Para esta combinação MIG/MAG curto-circuito, as tecnologias têm caminhado para o uso de processos derivativos, proporcionando o controle da transferência metálica, onde o processo passa a ser denominado de curto-circuito controlado [3]. 
Considerando-se a constante necessidade de inovação, mesmo para esta versão relativamente recente do GMAW, a empresa Fronius apresentou recentemente uma combinação de arco pulsado no arame-líder com o processo CMT. Sendo um processo ideal para a soldagem de alumínio devido ao método controlado de deposição de material e de baixa potência térmica [4].

Geralmente um procedimento de soldagem tem por objetivo a união de duas peças metálicas, que constituem uma junta de configuração preestabelecida ou o recobrimento de uma superfície também conhecida. A adição de metal se efetua em um amplo campo de domínio da soldagem, onde se considera na especificação de seus procedimentos: a acessibilidade, projeto da junta a ser soldada, parâmetros e variáveis processuais que possam conferir á geometria a qualidade desejada à solda [5].

Por outro lado oleodutos e gasodutos são estruturas de transporte de petróleo e gás a larga escala, cujas estruturas são constituídas pela união sequencial de dutos de aço carbono de pequeno, médio e grande porte [6]. A utilização de dutos terrestres e marítimos é considerada a forma mais econômica e confiável de transporte de combustíveis, sendo que no Brasil, um país continental, a construção de dutos é uma necessidade socioeconômica, face à expansão dos centros industriais, no transporte da área de óleo e gás além de água, resíduos e minérios [7].

Em 2014, o Brasil contava com 601 dutos destinados à movimentação de petróleo e seus derivados, gás natural e outros produtos, perfazendo 19,7 mil km. Destes, 150 dutos (14,3 mil km) eram destinados ao transporte e $451(5,4 \mathrm{mil} \mathrm{km})$ à transferência. [8]. Demonstrando claramente que a demanda na produção de petróleo implica na ampliação da malha dutoviária e consequentemente na melhoria da tecnologia e da qualificação da mão de obra empregada.

Ainda atualmente, o meio de soldagem mais utilizado em união de tubos é o processo de soldagem com eletrodo revestido ER ou SMAW (Shielded Metal Arc Welding) [9], tanto para o passe de raiz, quanto para os passes de enchimento e acabamento. Este processo de soldagem mostra limitações, não em relação a sua viabilidade e/ou qualidade da solda produzida (controle metalúrgico), mas em associação a baixa produtividade entre outros.

Com o propósito de que as fraquezas inerentes ao processo ER sejam eliminadas, se não diminuídas, está se tornando comum o emprego, em campo, de outros processos de soldagem, ou combinações destes, visando o aumento de produtividade, melhorando a qualidade da solda produzida [10]. Por conseguinte, salientando-se o processo de soldagem GMAW derivativo como alternativa na soldagem de passes de raiz, pois apresenta um refinado controle eletrônico da corrente e de tensão de soldagem, garantindo assim um bom controle da poça de fusão, boa penetração e baixo aporte de calor.

A soldagem de raiz em tubos de parede espessa é de grande importância para vários segmentos da economia, como as do petróleo e gás, naval e civil. Um vez que este controla a velocidade de 
execução do projeto de união de tubos toda vez que há detecção de defeitos neste passe, pois, determinará a perda de tempo pela retirada do material depositado para concertar os defeitos.

Segundo Lamond [11], o ideal para o passe de raiz é que seja realizado sem cobre-junta nem sistemas internos que produza ainda um cordão de raiz com um bom metal de solda com suficiente deposição para assegurar uma boa espessura de cordão. Esta solda deverá também não apresentar mordeduras, falta de fusão ou porosidades e deverá apresentar propriedades mecânicas apropriadas.

\subsection{DEFINIÇÃO DO PROBLEMA E MOTIVAÇÕES}

Para a soldagem de peças de grande espessura uma alternativa é o uso da técnica de "chanfro estreito" (narrow gap), que pode ser aplicada com vários processos, como o arco submerso, MIG/MAG e TIG. Dentre as vantagens está a de diminuir o volume de material a ser depositado e, consequentemente, o tempo gasto no processo.

Na utilização do processo GMAW em soldagem de chanfro estreito, a complexidade principal encontrada é lograr que o arame-eletrodo e o gás de proteção cheguem às regiões mais profundas do chanfro, de modo a garantir uma alimentação do material a ser depositado, sem problemas de proteção gasosa. Além disso, é necessário conseguir uma adequada penetração da poça fundida, tanto no fundo do canal de soldagem como nas margens laterais do chanfro.

Dependendo do projeto, diferentes procedimentos e/ou metodologias podem ser executadas para a realização do passe de raiz. Assim, o passe de raiz pode ser depositado pela parte interna ou externa do tubo em uma soldagem ascendente ou descendente; uma separação entre as partes a serem unidas, chamada de abertura de raiz pode ser utilizada obstaculizando até certo ponto, pois, necessita conservar constante a abertura ao longo do perímetro do tubo, desde o posicionamento até a realização da soldagem.

Em algumas situações, na soldagem externa do passe de raiz, é necessário utilizar matajunta(cobre-junta), de cobre, com a intenção de evitar vazamentos e limitar o exagero no reforço da raiz do cordão, fazendo causar inclusões do cobre nesta área, podendo originar porosidades, trincas e até corrosão. Esta mata-junta é posicionado por pressão na linha interna de encosto dos tubos a serem soldados perante uma "acopladeira", a qual serve também para o alinhamento dos mesmos. O uso de acopladeira é um gasto adicional ao processo de soldagem, além do tempo gasto no posicionamento da mesma dentro dos tubos.

Quando não se usa abertura de raiz, na soldagem de topo em soldagem externa do tubo, um fator determinante na configuração da junta é a face de raiz ou nariz, pois a altura ou espessura dela é a que permite ou dificulta uma total fusão refletida em penetração, para um determinado 
conjunto de parâmetros de soldagem.

Um bom passe de raiz é conseguido em testes preliminares por tentativa e erro, escolhendo-se os parâmetros de soldagem e uma configuração de junta, se a penetração total não é obtida, os valores dos parâmetros de soldagem vão sendo modificados até conseguir penetração desejada ou, caso contrário, se mantêm constantes os parâmetros de soldagem e vai-se modificando a configuração da junta, especificamente a espessura da face de raiz.

A soldagem de tubos utilizando a solda manual é um processo complexo, principalmente quando se desejam soldas de responsabilidade, isto é, onde o nível de qualidade exigido é muito elevado. Dependendo da posição de soldagem, as variáveis devem ser alteradas para que se evite o escorrimento do cordão o que comprometeria a qualidade da solda.

A automatização da soldagem de tubos torna-se necessária, pois o soldador pode configurar as variáveis de cada setor circular do tubo antes de realizar a solda. O trabalho de câmbio de variáveis fica a cargo da unidade de controle do sistema automatizado. Este sistema existe no mercado internacional e é utilizado, tanto para a soldagem de tubos de parede fina, como de parede espessa utilizando o processo GMAW derivativo.

Entende-se, também, que um dos problemas na maioria dos laboratórios de pesquisas na realização de estudos em soldagem de tubos ou soldagem circunferencial é, consequentemente, a obtenção dos tubos. Isto se deve à falta de provedores ou poucos fabricantes e ao alto custo dos mesmos, além das despesas e da perda de tempo que originam o transporte destes tubos desde o ponto de fornecimento até o centro de pesquisa. As despesas, diminuem se os testes fossem realizados em chapas planas, considerando-se o mesmo material ou que se comporte da mesma maneira metalurgicamente. 


\subsection{OBJETIVOS}

Com o propósito de melhorar e até mesmo resolver alguns dos problemas aqui apresentados, fez-se a utilização de uma estrutura que permita fazer a união por meio de soldagem de corto circuito derivativo CMT em três posições criticas de soldagem (Plana, Vertical e Sobrecabeça) com chapas planas, soma-se a isso com todas as características de uma soldagem orbital convencional, ou seja, em tubos.

Além disso, neste trabalho é apresentada uma metodologia denominada "Metodologia do chanfro com nariz decrescente", com a finalidade de encontrar, para um determinado conjunto de parâmetros de soldagem, a espessura do nariz apropriado para uma soldagem de topo, sem abertura de raiz em chapas para logo ser validado em tubos.

\subsubsection{Objetivo Geral}

Pretende-se com esta abordagem, atingir o objetivo principal deste trabalho que é:

Adotar uma metodologia para aplicação de soldagem de topo em penetração completa, com passe de raiz em juntas de chanfro estreito com processo GMAW-CMT, utilizando chapas planas em três posições críticas de soldagem (Plana, Vertical, Sobrecabeça), assim, empregar planejamentos experimentais para que logo possa ser revalidado em sodagem orbital de meia volta descendente em posição 5G, isto aplicado em um tubo com processo GMAW convencional utilizando dois tipos de arames consumíveis.

\subsubsection{Objetivos Específicos}

(a) Construir uma estrutura que permita fazer a soldagem de chapas planas com chanfro estreito em U em posições criticas de uma soldagem orbital.

(b) Utilizando-se a "Metodologia do chanfro com nariz decrescente", pretende-se facilitar a realização dos testes para o passe de raiz, por meio de planejamentos experimentais que estabeleçam um conjunto de parâmetros, com o intuito de obter a mesma espessura de nariz(geometria da junta) nas posições críticas de soldagem estipuladas.

(c) Realizar a soldagem orbital, aplicando-se os resultados obtidos nos itens anteriores, validando com isto a metodologia proposta e os equipamentos desenvolvidos neste trabalho.

(d) Fazer ensaios de macrografia nos testes controlados para detectar defeitos internos nas juntas soldadas para verificar a penetração total em passe de raiz. 
(e) Na soldagem orbital fazer uma análise do uso de dois tipos de arame com a finalidade de fazer a uma inspeção visual e logo comparar a potência de soldagem necessária para fazer um passe de raiz.

\subsection{ESTRUTURA DO TRABALHO}

Para alcançar os objetivos propostos, este trabalho foi estruturado em 6 capítulos que abordam os seguintes assuntos:

- Capítulo 1 - Introdução. A relevância do tema escolhido, os objetivos pretendidos e as contribuições que serão atingidas mostrando para isto uma estrutura do trabalho.

- Capítulo 2 - Revisão Bibliográfica. Discorre-se aqui dos conceitos principais relativos ao trabalho. Faz-se uma abordagem no processo de Soldagem GMAW. As Juntas de Soldagem, Passe de Raiz empregado em soldagem de tubos, junto ao planejamento experimental a ser utilizado para encontrar os parâmetros ótimos para passe de raiz com chanfro estreito em U e o Cálculo da Potência de soldagem para avaliar todas as etapas e finalmente a revisão da literatura especializada nas áreas a trabalhar na metodologia experimental.

- Capítulo 3 - Metodologia Experimental. Neste capítulo é descrita a forma ou a metodologia como foi realizado este trabalho, usando os equipamentos referidos no capítulo 3. Para isto, dentro deste capítulo foram consideradas 3 etapas de testes, como detalhadas a seguir:

- $1^{a}$ etapa: Foram realizados testes de validação de parâmetros da literatura, usando chapas de aço ABNT 1020, com 6,0 mm de espessura, com o propósito de procurar os parâmetros apropriados para executar a soldagem de passe de raiz na posição plana, vertical no sentido descendente e sobrecabeça, que apresente um cordão com boas características visuais e sem defeitos internos.

- $2^{a}$ etapa: Aplicando-se a "Metodologia do chanfro com nariz decrescente", e com os parâmetros de soldagem apropriados encontrados na 1a etapa, junto com a ajuda de organização dos experimentos de planejamento Composto Central, para logo ser aplicada a teoria de Desirability (otimização de múltiplas respostas), usando-se chapas de aço ABNT 1020, com 12,7 mm de espessura sendo determinada a mesma espessura de nariz ideal nas posições criticas estabelecidas. Logo, foram validados em juntas construídas com essas espessuras de nariz.

- $3^{a}$ etapa: Finalmente é realizada a soldagem orbital convencional em tubos de aço ASTM 106 com 12 polegadas de diâmetro externo e 9,7 mm de espessura de parede, 
usando-se, na configuração da junta, a espessura do nariz encontrada, e finalmente fazer um análise desta soldagem com dois tipos de arames.

Para melhor elaboração e entendimento, estas três etapas são representadas no fluxograma de desenvolvimento do trabalho na Fig. 1.1.

- Capítulo 4 - Testes e Resultados. Neste capítulo são apresentados os resultados obtidos dos experimentos, além das discussões acerca dos mesmos.

- Capítulo 5 - Conclusões e trabalhos futuros. As conclusões finais do trabalho são aqui apresentadas assim como também algumas sugestões para futuros trabalhos. 


\section{Soldagem Orbital meia volta Descendente}

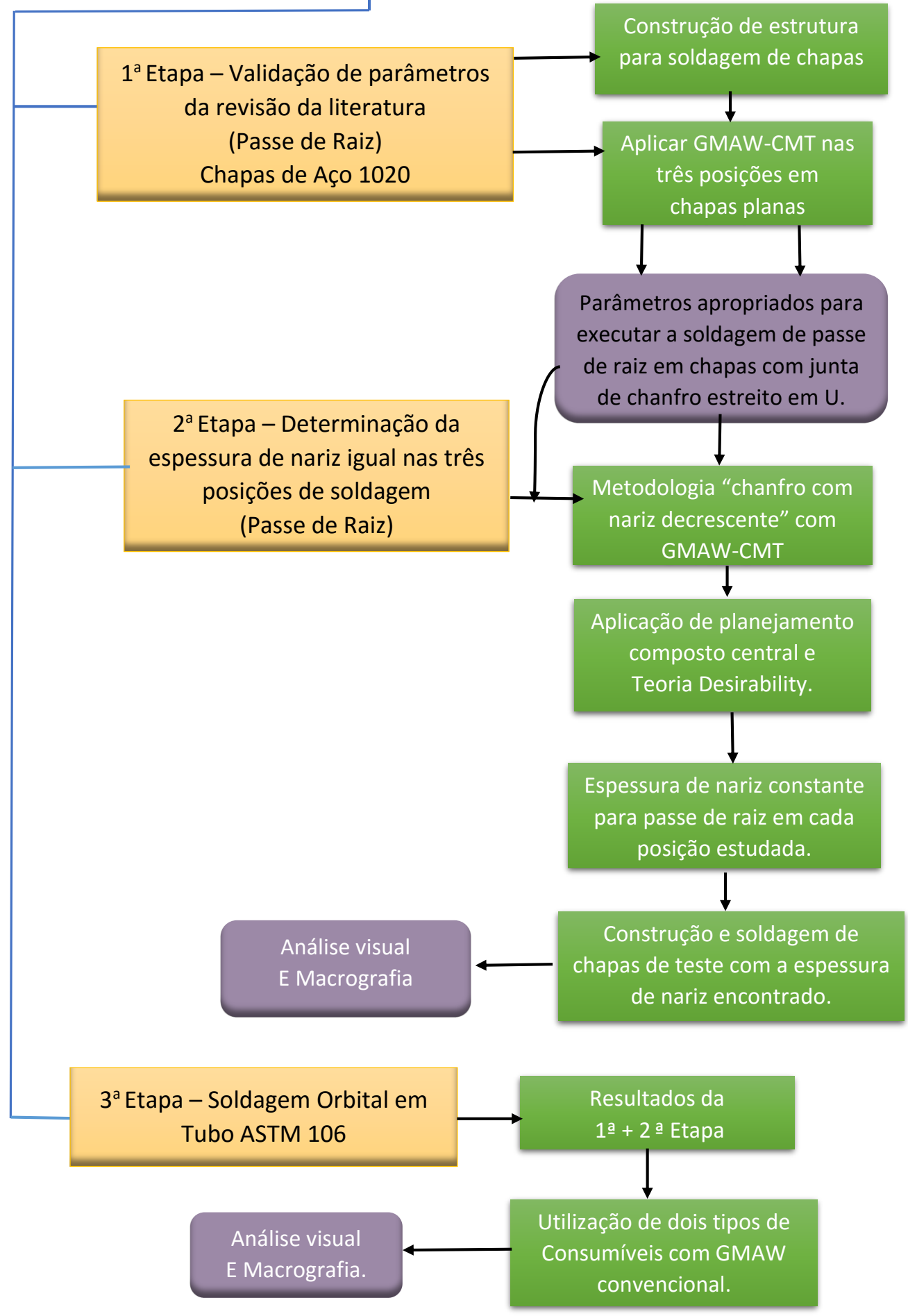

Figura 1.1. Fluxograma de desenvolvimento do trabalho 


\section{REVISÃO BIBLIOGRÁFICA}

Este capítulo retrata a fundamentação teórica do processo soldagem GMAW utilizando uma fonte de controle de curto circuito derivativo e convencional. Empregando a metodologia de união de chapas planas e tubos por meio de juntas de chanfro estreito em passe de Raiz, a metodologia experimental a utilizar e o cálculo da potência de soldagem e finalmente uma revisão da literatura especializada onde se amostram pesquisas que ajudaram a desenvolver este trabalho.

\subsection{PROCESSO DE SOLDAGEM GMAW}

O processo de soldagem GMAW, por definição, é um processo de soldagem ao arco elétrico que produz a coalescência de metais pelo aquecimento do arco, estabelecido entre um eletrodo de metal alimentado continuamente, e a peça de trabalho [12]. A região de solda é protegida por uma atmosfera de gás inerte (comercialmente $\mathrm{Ar}$ e $\mathrm{He}$ ) ou ativo $\left(\mathrm{CO}_{2}\right)$ ou de misturas (onde pode incluir $\mathrm{N}_{2}$ o $\mathrm{O}_{2}$ ), onde o processo é conhecido por acrograma MIG/MAG, onde MIG representa "Metal Inert Gas" (proteção por um gás, ou mistura, inerte) e MAG, "Metal Active Gas" (mistura de um ou mais gases ativos com gases inertes ou $\mathrm{CO}_{2}$ puro). Por conseguinte o arame-elétrodo, sendo alimentado continuamente, funde no calor do arco e gotas de metal líquido de algum modo e são transferidas de forma intermitente para a poça de fusão, formando assim o cordão de solda. A formação das gotas de metal é governada por vários fatores como: equilíbrio de forças que atuam sobre a gota, fenômenos térmicos no arame, calor transferido da coluna de plasma e a distribuição da densidade de corrente na gota de metal. O balanço entre os fatores determina a forma, o volume e a frequência de destacamento das gotas que são formadas na ponta do arame, que por sua vez caracterizam os modos de transferência metálica no processo de soldagem [13]. A sigla GMAW abrange o uso de qualquer tipo de gás de proteção [14]. A Fig. 2.1 ilustra os principais componentes intervenientes deste processo.

Por conseguinte, as características mais importantes deste processo são a alta produção (massa de material depositado por unidade de tempo) e a facilidade de ser produzida sua aplicação automática, possibilitando a aplicação de meios auxiliares (manipuladores, robôs, carros 
tracionados, etc.) para deslocamento da tocha de soldagem, atendendo a aplicações em que são requeridas elevada produtividade e repetibilidade [15].

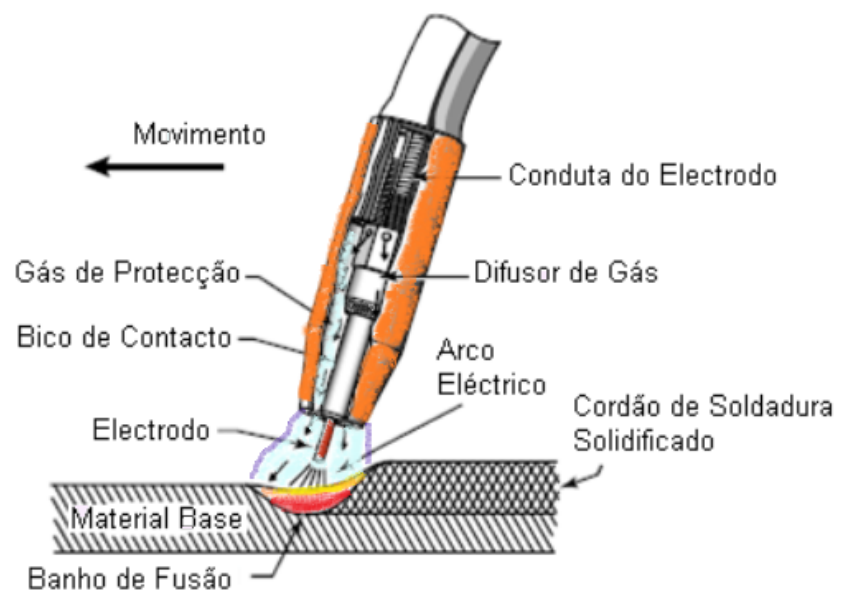

Figura 2.1. Componentes intervenientes no processo de soldagem GMAW [16].

\subsubsection{Processo GMAW Convencional}

O processo de soldagem convencional tem relação direta com a transferência por curtocircuito, já que utiliza tensões baixas e correntes não muito elevadas, e diâmetros de eletrodos menores, frequentemente limitados para arames de até $1,2 \mathrm{~mm}$ de diâmetro. Este processo é caracterizado pelo toque periódico da gota (pequena, de tamanho próximo ao diâmetro do eletrodo) na poça de fusão no momento de sua transferência [17]. Sob ação das forças acima descritas, esta gota começa a se constringir assumindo a forma cilíndrica, formando a chamada ponte metálica, qualificada como estável quando chega ao mesmo diâmetro do arame-eletrodo em todo o seu comprimento [18]. O sentido acima é bem conhecido e é descrito, também como oscilo-graficamente no esquema da Fig. 2.2.

Abordando o aspecto oscilográfico da Fig. 2.2, observa-se que ao ocorrer o curto-circuito a corrente entra em uma rampa de subida, um transitório, pois a fonte de energia tenta impor uma tensão entre seus terminais de saída, ou seja, entre a peça e o arame-eletrodo. A inclinação da rampa ocorre em função da tensão regulada e da indutância. Esta transferência é muito utilizada em soldagens de chapas finas, em todas as posições ou na soldagem de passe de raiz em juntas tubulares [17].

Durante o curto-circuito, como a corrente cresce e a área do condutor diminui pela constrição da ponte metálica. O efeito Pinch e a componente axial da força de Lorentz crescem em taxa também crescente, pois são proporcionais ao quadrado da corrente e a sua densidade. Assim 


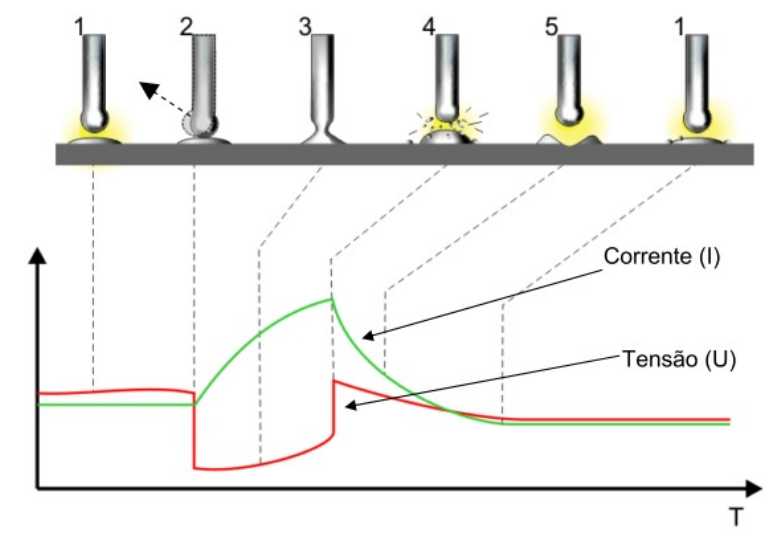

Figura 2.2. Curso da transferência metálica por curto-circuito no processo GMAW convencional [18]

que a ponte se desfaz o arco é novamente estabelecido. Neste momento, a corrente está em um nível alto, e a tensão ultrapassa seu valor regulado. A fonte impõe a tensão regulada, causando a redução na corrente. A corrente, durante o arco, causa a formação de uma nova gota metálica e mantêm o aquecimento da poça fundida. Os itens a seguir tratam mais profundamente os aspectos da transferência metálica por curto-circuito cujo domínio foi considerado fundamental para o desenvolvimento do CCC (Curto-Circuito Controlado) o também chamado Derivativo.

\subsubsection{Parâmetros de regulagem}

Os parâmetros de regulagem do processo GMAW com transferência por curto-circuito podem influenciar no desempenho do processo e nas características geométricas do cordão de solda. Desta maneira, é de fundamental importância o conhecimento da influência destes parâmetros no comportamento do processo, onde, em seguida, são descritas as influências dos parâmetros que serão avaliados neste trabalho. Ressalta-se que outros parâmetros como comprimento energizado do eletrodo, indutância, gás de proteção, diâmetro/material do eletrodo, dentre outros, também possuem destacada influência sobre o processo, mas não são objetos de avaliação neste trabalho.

- Tensão de soldagem. O ajuste da tensão de soldagem é responsável por regular o comprimento do arco de forma que o aumento da tensão implica em um arco mais longo. $\mathrm{Na}$ soldagem por curto-circuito propõe níveis mais baixos de tensão, pois, utiliza-se arco mais curto. Quanto a formação do cordão de solda, a regulagem da tensão de soldagem pode influenciar na aparência, penetração e as propriedades do cordão de solda [17]. De acordo com Santos [19], menores valores de tensão tendem a formar cordões mais estreitos. Ademais, o comprimento do arco (regulado pela tensão) pode influenciar na geração de respingos. 
- Velocidade de soldagem. A velocidade de soldagem representa a taxa de deslocamento do arco ao longo da junta, sendo ajustada de acordo com o volume desejado do cordão de solda. Assim, com a redução da velocidade de soldagem, aumenta a quantidade de material depositado por unidade de comprimento da solda. De acordo com Junior [20], o controle da velocidade de soldagem também pode controlar a penetração do cordão de solda. O aumento da velocidade de soldagem favorece um menor calor imposto e consequentemente um cordão com menor penetração. Porém, o ajuste da velocidade de soldagem em níveis muito baixos pode resultar na redução da penetração. Neste caso, a velocidade de soldagem muito baixa aumenta o volume da poça de fusão, passando então o calor do arco a atuar sobrepondo o cordão não diretamente na poça de fusão, desse modo reduzindo a penetração [21].

- Corrente de Soldagem. No processo GMAW operando com fonte de tensão constante, a corrente de soldagem do arame está diretamente relacionada com a velocidade de alimentação e com a taxa de deposição. Com o aumento da corrente de soldagem se tem uma maior taxa de fusão obtendo uma maior alimentação de arame. Quanto a influência na geometria do cordão, de acordo com Junior [20]. A penetração e o reforço aumentam com a ampliação da corrente de soldagem (é igual ao aumento da velocidade de alimentação do arame). Também se a corrente é demasiado baixa, podem resultar reforço muito pequeno e penetração inadequada ou incompleta, ademais conduz a um arco instável.

\subsubsection{Soldagem Por Curto-Circuito Controlado}

Nos últimos anos, a evolução de tecnologias do processo GMAW tornou-se mais significativa para automação e controle de soldagem [22] [23]. Do mesmo modo, novas abordagens de soldagem foram introduzidas nos últimos dez anos, utilizando-se novos sistemas de controle; as fontes de alimentação podem gerar mais exatidão e precisão com uma melhoria substancial no controle do arco. Na verdade, as novas gerações de fontes de alimentação fornecem um controle mais preciso de transferência de metal com grandes benefícios para a estabilidade do arco [2].

Os processos de soldagem que efetuam uso da transferência por curto-circuito controlado são processos derivativos do GMAW com transferência por curto-circuito convencional, nos quais utilizam métodos de controle externo para melhoria da transferência metálica. O desenvolvimento destes processos tem como objetivo aproveitar as vantagens da transferência metálica por curto-circuito, tais como menor aporte térmico e a capacidade de realizar soldas em todas as posições, eliminando ou reduzindo os inconvenientes do processo convencional, como a alta geração de respingos e fumos, além da irregularidade na transferência metálica [24].

Considerando-se a constante necessidade de inovação, mesmo para esta versão relativamente 
recente do GMAW, a empresa Fronius apresentou, recentemente uma nova tecnologia de soldagem patenteada como "Cold Metal Transfer" (CMT). Por meio desse modo controlado do processo de soldagem GMAW que a transferência de gota é baseada em uma oscilação mecânica do arame-eletrodo [25]. Consiste em, quando o arco plasmático é estabelecido o arame se move para a poça de fusão até que a toque, momento em que ocorre o curto-circuito, logo a corrente torna-se menor e o eletrodo é retraído com o propósito de melhorar o destacamento da gota [26].

\subsubsection{Processo GMAW-CMT}

O processo GMAW-CMT (Gas Metal Arc Welding - Cold Metal Transfer) produzido pela empresa Fronius e patente solicitada em 2005 [27], mostra uma forma mecânica de controle do arco. Sendo um processo de curto-circuito controlado designado pela solução adotada para destacar a gota, que ao invés de usar impulso de corrente, utiliza um sistema mecânico para o movimento de recuo do eletrodo, associado à modificação do formato de onda da corrente de soldagem, adaptada a partir do controle eletrônico da fonte. O sistema reverte a alimentação do arame-eletrodo (para frente e para trás), por meio de cada curto-circuito, em seguida a fonte interrompe o fornecimento de energia, recua o arame-eletrodo separando a gota metálica da ponta do arame para poça de fusão, reduzindo a ação do efeito Pinch e garante uma transferência de forma suave. Este processo utiliza um arco curto com a corrente de curto-circuito limitada a um nível muito baixo, o que implica em aporte térmico muito baixo.

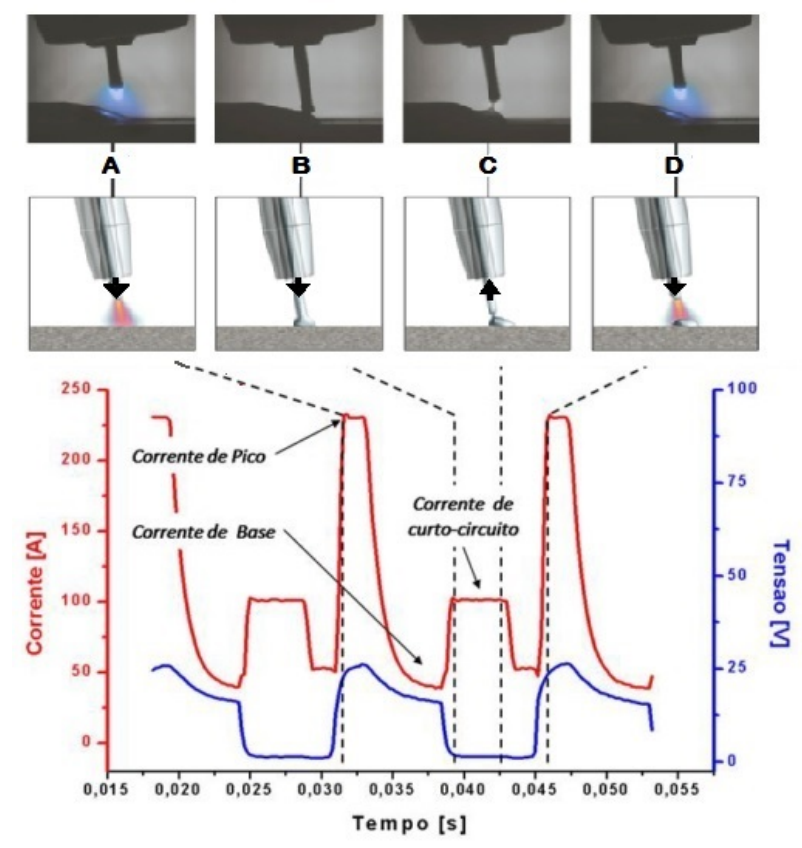

Figura 2.3. Oscilograma de tensão e corrente de soldagem em função do ciclo de transferência da gota para o processo CMT (Modificado de Costa [3]). 
No esquema da Fig. 2.3, o mecanismo de transferência metálica ocorre começando em A e indo até $\mathrm{D}$, como descrito a seguir:

- Fase A - Durante o período de arco o metal de adição é movido em direção á poça de fusão.

- Fase B - No instante em que o metal de adição toca a poça, o arco é extinguido e o curtocircuito ocorre. Entretanto o controle eletrônico da fonte limita essa corrente de curtocircuito e a mantém até que o movimento de retração do arame seja iniciado.

- Fase C - O movimento de recuo do arame-eletrodo vai ajudar o mecanismo de desprendimento da gota durante o curto-circuito, permitindo que esta transferência se dê de maneira suave e com mínimos respingos. A corrente será em nível baixo.

- Fase D - O movimento de arame é revertido ao iniciar o processo novamente. Neste momento, e até que um novo curto aconteça, a corrente é a de pico. Este alto valor de corrente é responsável pela re-ignição do arco bem como pelo início da formação da gota.

Para melhor entendimento de como o arame-eletrodo promove um movimento de "vai e vem", a Fig. 2.4, apresenta uma montagem esquemática do processo GMAW-CMT onde existem 2 alimentadores de arame. O primeiro, indicado pelo número 5, é um alimentador convencional do processo GMAW. Porém, o alimentador em destaque Fig. 2.4(b) é o grande desenvolvimento do processo de "Transferência Metálica Fria" responsável por executar o avanço e o retrocesso do arame nas condições descritas anteriormente. Este alimentador é montado na própria tocha, onde há os roletes que impulsionam o arame. Quando ocorre o retrocesso do arame-eletrodo por parte do alimentador da tocha, o alimentador traseiro continua empurrando o arame para a tocha. Para não haver um deslizamento sobre os roletes, ou mesmo uma compressão excessiva sobre o arame, o cabo da tocha aloja um "pulmão", ou seja, um sistema que permite o armazenamento do arame que por um lado está sendo empurrado para frente e por outro (alimentador dianteiro) está sendo empurrado de volta. O sincronismo dos dois motores não é uma tarefa fácil e deve ser bem feita para que um motor não sobrecarregue o outro. Outra dificuldade deste processo é que devido a complexidade da tocha, o custo se eleva consideravelmente, além da dificuldade de operabilidade de um comprimento de arco por parte de um soldador, este processo precisa de automação [28]. 


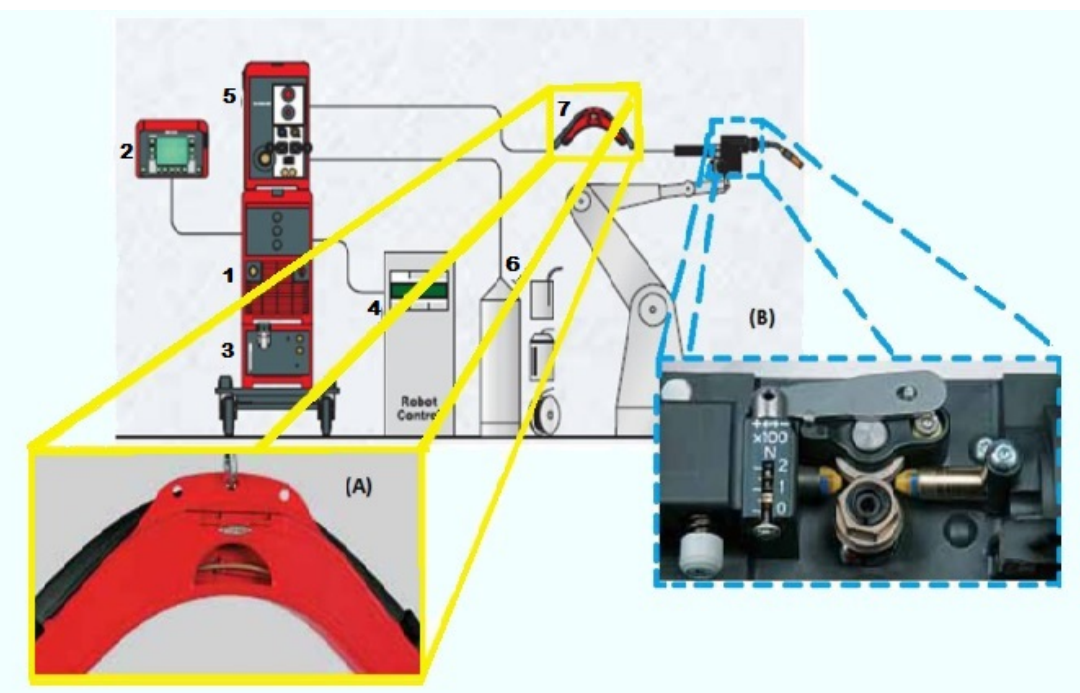

Figura 2.4. Montagem esquemática do processo CMT robotizado. Em detalhe: (a) Pulmão ou compensador de arame; (b) Alimentador dianteiro.(Adaptado de Fronius [26]).

Pode-se salientar outro ponto importante: a redução significativa da geração de calor na execução da solda, por meio da transferência com baixa corrente de curto-circuito. Observa-se na Fig. 2.5, que a faixa operacional do processo GMAW-CMT permite trabalhar com menores valores de energia, o que favorece a utilização deste processo na união de chapas finas [29].

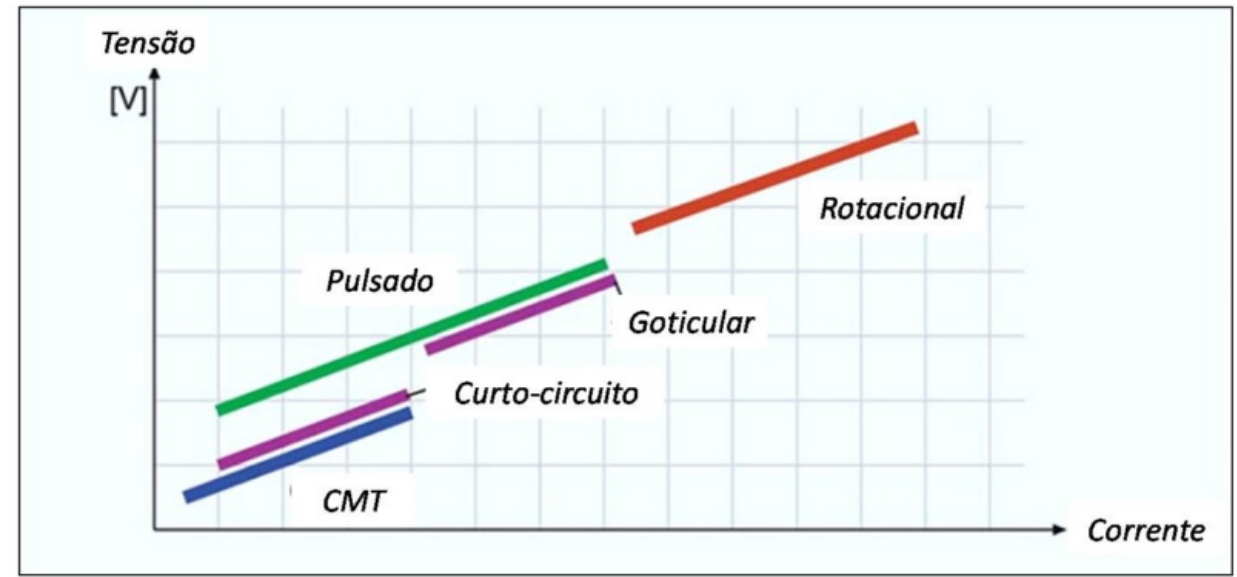

Figura 2.5. Esquema da corrente de transição para as transferências por curto-circuito convencional, curto-circuito controlado (CMT), pulsado, goticular (spray) e rotacional [25].

Finalmente, o GMAW-CMT é um modo de transferência baseado na mistura entre a transferência por curto-circuito e pulsado, sua transferência metálica depende dos parâmetros aplicados. A estabilidade do par corrente x tensão é garantida através dos controles eletrônicos, até mesmo no caso da transferência de gotas adicionais durante um ciclo de corrente e tensão [30]. 


\subsubsection{Parâmetros de regulagem}

Entre as variáveis que influenciam no desempenho do processo GMAW-CMT estão os parâmetros de regulagem do processo, que neste trabalho serão denominadas como: comprimento de arco; velocidade de alimentação de arame e velocidade de soldagem:

- Comprimento de arco (CMT). Está diretamente relacionado com a regulagem da tensão de soldagem, sendo responsável, como o próprio nome diz, pelo ajuste do comprimento do arco voltaico. A fonte permite regulagem de -30 a 30 , sendo que para valores negativos resulta em um comprimento de arco mais curto.

- Velocidade de Alimentação de Arame. A corrente de soldagem está diretamente relacionada à velocidade de alimentação do arame (desde que a extensão do eletrodo seja constante). Quando a velocidade de alimentação do arame é alterada, a corrente de soldagem varia no mesmo sentido. Em outras palavras, um aumento na velocidade de alimentação do arame causará aumento da corrente de soldagem ou vice-versa.

- Velocidade de Soldagem. Representa a taxa de deslocamento ao longo do arco da junta, sendo regulada de acordo com o volume desejado do cordão da solda, o controle da velocidade de soldagem influencia na penetração. O excesso de velocidade causa mordeduras, porosidade, forma do cordão irregular, fissuração e maior inclusão de escoria no metal de solda. Além disso, essa velocidade causa fusão incompleta nas paredes laterais, devido a um aquecimento insuficiente nas paredes. Velocidades de soldagem relativamente lentas provêm tempo para que os gases escapem desde o metal fundido, o que reduz a porosidade, ainda que uma velocidade excessivamente baixa produzisse uma forma do cordão convexa com inclusão de escoria e é possível atravessar o metal a soldar.

\section{$2.2 \quad$ JUNTAS DE SOLDAGEM}

Juntas (joint), em soldagem, se conferem a região entre duas o mais peças que serão unidas. As juntas comumente são utilizadas em estruturas de aço, chamadas de "metal de base" (Material da peça que passa pelo processo de soldagem), tendo como tipos de juntas: de topo (butt), de ângulo (tee), de canto (corner), sobreposta (lap) e de aresta (edge). Por tanto as soldas em juntas de topo e ângulo podem ser de penetração total (penetração em toda a espessura de um dos componentes da junta) ou parcial. Deste modo soldas de penetração total apresentam melhor comportamento mecânico, contudo, tendem ser de execução mais difícil. Assim, quando o melhor desempenho destas não for necessário, o usual é trabalhar com soldas de penetração parcial [31], A Fig 2.6. Mostra os tipos de Juntas expostos anteriormente. 


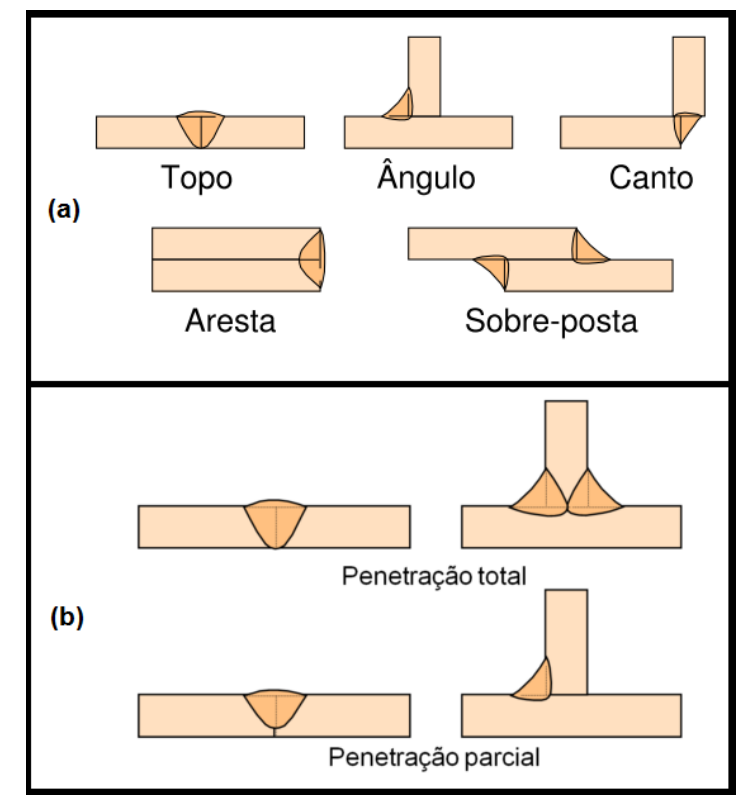

Figura 2.6. (a)Tipos de Juntas e (b)Penetração total e parcial [31]

O formato do chanfro na junta tem grande influência no comportamento, respeito a eficiência e na confiabilidade da junta de topo, de modo que a seleção de sua geometria deve ser efetuada de acordo com o tipo de aplicação. Em muitas ocasiões, as dimensões e o formato dos chanfros padronizados são ligeramente modificados pela experiência do próprio construtor, justamente para adaptar-se ao tipo de aplicação da estrutura soldada sem que isto acarrete diminuição da qualidade da junta soldada [32]. A Fig 2.7, apresenta as partes que conformam uma junta de topo:

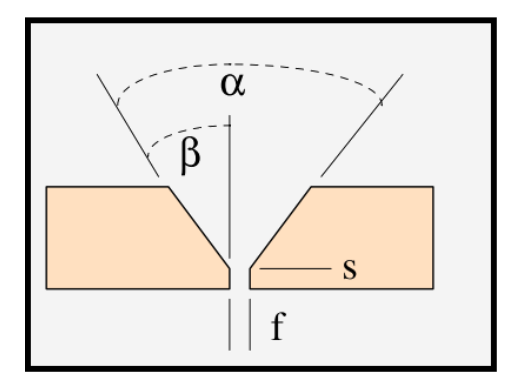

Figura 2.7. Elementos de um Chanfro [31]

- Encosto ou nariz $(S)$ (nose, groove face): Parte não chanfrada de um componente da junta.

- Abertura, folga ou fresta $(f)$ (root opening): Menor distância entre as peças a soldar.

- Ângulo de abertura da junta $(\alpha)$ (groove angle).

- Ângulo de chanfro $(\beta)$ (bevel angle).

Os elementos de um chanfro são escolhidos de forma a permitir um fácil acesso até o fundo da junta, porém, com menor necessidade de metal de adição [31]. 


\subsubsection{Juntas de Chanfro Estreito}

Com a atual necessidade de aumentar a produtividade na união de componentes metálicos, desenvolveu-se novas formas de soldagem nos últimos 30 anos, para a obtenção da redução no tempo de fabricação. Uma das necessidades é o aumento da taxa de fusão do eletrodo. Outra é utilizar uma geometria da junta que permita reduzir a quantidade de material que é necessário depositar para preenchê-la [33].

Na direção da segunda opção citada acima, os meios de produções atuais possuem certas limitações que impossibilitam uma diminuição acentuada do ângulo do chanfro, existe uma maior relevância quando a soldagem de chapas possuem grandes espessuras acima de $50 \mathrm{~mm}$ [15]. Nos tempos atuais, as técnicas de soldagem em chanfro estreito permitem a união de chapas de até $300 \mathrm{~mm}$ de espessura, utilizando uma junta de soldagem com chanfro reto ou, então, com chanfros em " $V$ " com pequeno ângulo, menor do que $10^{\circ}$ de preparação (para compensar a deformação angular que ocorre pela contração da solda e que poderia fechar a junta), não possuindo uma abertura na parte mais estreita, maior que $12 \mathrm{~mm}$ [34].

As técnicas de soldagem em chanfro estreito recebem diferentes denominações em inglês: "narrow gap welding", "narrow groove welding" e "deep groove welding" [34]. Na escassa literatura existente em português a denominação é padrão. Denomina-se sempre soldagem em chanfro estreito [35]. A soldagem em chanfro estreito foi destinada a reduzir o volume de metal de solda em soldagem de chapas grossas aumentando a produtividade na soldagem de topo, por meio da diminuição da quantidade de material que seria necessário depositar no chanfro. Reduzindo custos de soldagem, tempo e nível de distorções. Essa técnica de soldagem foi desenvolvida na União Soviética,nos Estados Unidos e no Japão nos anos de 1957, 1960 e 1966, respectivamente, pontuando que no Japão era a mais utilizada na década de 80 [36] [37].

A soldagem em chanfro estreito não é um processo e sim uma técnica de deposição de cordão, associada com um processo de soldagem por arco, caracterizado por um número constante de cordões por camada [38]. Este procedimento de soldagem usa juntas preparadas com pequenos ângulos, tipicamente na faixa de $2-20^{\circ}$, o qual diminui a quantidade de metal a ser depositado, menor tempo de soldagem para o preenchimento, significando menor calor fornecido ao metal de base reduzindo com isto possíveis distorções, além de aumentar a produtividade [39]. No setor de construção de tubulações, a soldagem de passe de raiz em chanfro estreito é muito importante no termo qualidade e produtividade.

Da mesma forma esta técnica pode ser utilizada com vários processos de soldagem a arco, como o GMAW, SAW e GTAW. Para se referir à aplicação desta técnica com diversos processos, a Associação Americana de Soldagem AWS (American Welding Society), definiu a seguinte 
nomenclatura:

- NG-GMAW (Narrow Gap Gas Metal Arc Welding), para a soldagem GMAW em chanfro estreito.

- NG-SAW (Narrow Gap Submerged Arc Welding), para a soldagem a arco submerso em chanfro estreito.

- NG-GTAW (Narrow Gap Gas Tungsten Arc Welding), para a soldagem GTAW em chanfro estreito.

Por tanto, a natureza desta técnica requer um controle preciso para garantir uma alta qualidade de soldagem. Já que um pequeno desvio do centro da linha de encosto pode resultar em defeitos de falta de fusão, devido ao arco e poça de fusão serem direcionadas ao lado das paredes do chanfro. Grande atenção se deve ter com a usinagem do chanfro. A Fig 2.8. mostra a área que deve ser preenchida em uma junta de chanfro estreito e em uma junta em "V" convencional, para espessura de parede de $10 \mathrm{~mm}$. Pode-se ver que a junta do tipo chanfro estreito em "U" tem uma área menor em 16,9 $\mathrm{mm}^{2}$, que representa $45,8 \%$ a menos de área a ser preenchida.
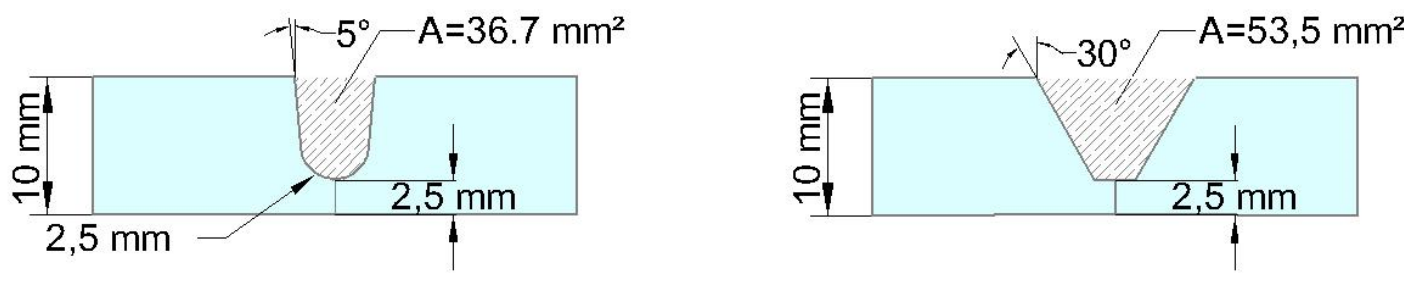

Figura 2.8. Diferença entre as áreas a serem preenchidas considerando chanfro estreito e chafro em "V"

\subsection{PASSE DE RAIZ}

O passe de raiz é o primeiro cordão de solda a ser efetuado no chanfro durante a soldagem de chapas e união de tubos, seguido do passe de enchimento e passe de acabamento, salientando que na execução de soldas de qualidade o passe de raiz tem significado especial por representar na construção mecânica soldada, o alicerce ou fundação na edificação de estrutura metalúrgica básica que sustentará os cordões posteriores, além disso, é o passe mais difícil de ser depositado, já que requer um soldador experiente para fazer um bom cordão ao redor da junta, também a velocidade de realização deste passe determina a velocidade com a qual a linha de produção de soldagem é construida, assim, qualquer atraso no passe de raiz atrasa o projeto. 
O processo de soldagem mais empregado no Brasil e no resto do mundo para soldas de tubos em passe de raiz, é depositado manualmente com eletrodo revestido ER (ou SMAW) [10]. Pelo qual pode ser usado em diferentes posições de soldagem, com velocidades relativamente baixas, apresentando limitações, não em relação a sua viabilidade e/ou qualidade da solda produzida, mas em relação a baixa produtividade.

Atualmente, os passes de raiz também são realizados com processo GMAW na variante denominada STT (Surface Tension Transfer), a qual disponibiliza um controle eletrônico da corrente e da tensão de trabalho, conseguindo desta forma um melhor controle do aporte na raiz da junta, e uma transferência metálica sem respingos, por tensão superficial, ou seja, a gota é destacada quando está em contato com a poça, sendo esta técnica empregada com limitações [5].

No Canadá na montagem de gasodutos, está sendo testado o processo híbrido de soldagem, referindo-se a combinação de soldagem de faixe laser, com outro processo de soldagem par melhorar ainda mais a produtividade. Como o LASER GMAW (Nd: YAG) (Light Amplification by Stimulated Emission of Radiation Neodymium-Doped Yttrium Aluminium Garnet; Nd: $\left.Y_{3} A_{5} O_{12}\right)$. O processo é conhecido como laser de fibra, uma vez que emprega fibra ótica como cabo extensível da tocha de soldagem, juntamente com o processo GMAW [40]. Este método de soldagem permite que a penetração da solda seja incisiva na raiz, apesar da elevada espessura, e preenche-se em passe único. Geralmente a potência do LASER Nd: YAG é tida como o de melhor eficiência energética. Para a soldagem dos aços são necessários $10 \mathrm{~kW}$ para uma penetração de até $10 \mathrm{~mm}[41]$.

Lamond [11] expõe três métodos principais para a realização do passe de raiz:

- Passe de raiz externo com abertura de raiz.

- Passe de raiz externo sem abertura de raiz, com cobre-junta interna.

- Passe de raiz interno sem abertura de raiz.

Portanto nos métodos já mencionados, onde o passe de raiz externo com ou sem abertura de raiz, pode ou não ser utilizado cobre-junta. Algumas configurações das juntas usadas para estes métodos ou condições são mostradas na Fig. 2.9.

Porém, problemas ou limitações existem nestes métodos, por exemplo: quando se emprega uma junta que use mata-junta de cobre, existe a possibilidade de ocorrer inclusões do cobre na raiz do cordão. Também, as dificuldade e tempo empregado quando ao posicionamento do tubo para manter uma abertura de raiz constante, ao longo do perímetro do tubo, antes da soldagem. 

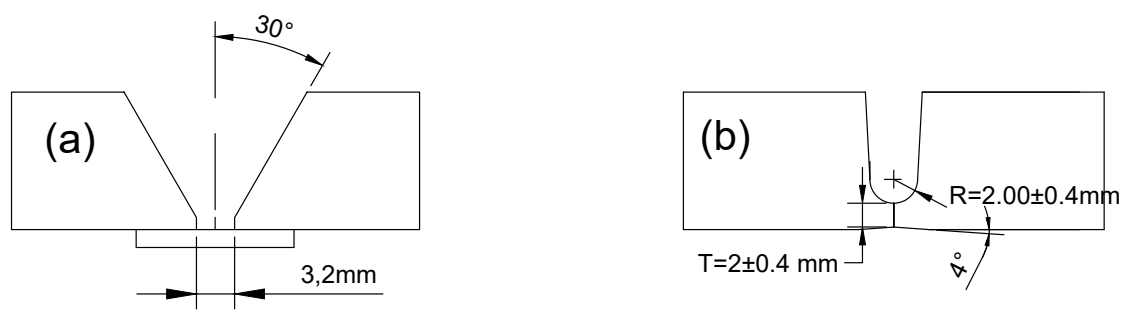

\section{SERIMER: Externo}

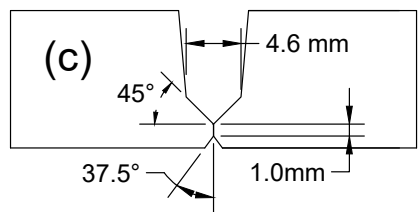

WERC : Interno/Externo

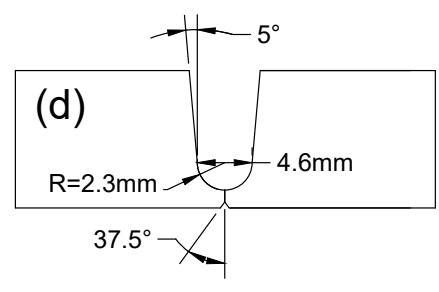

WERC : Externo

Figura 2.9. (a) Junta de Topo em "V" básica com cobre-junta, (b), (c) e (d) juntas de Topo em chanfro estreito [23].

Lamond [11] expressa que um processo de soldagem com qualidade deve ser aquele que facilite uma soldagem de passe de raiz sem cobre-junta que tenha uma aceitável deposição para obter uma boa espessura de cordão. Esta solda não deve conter mordeduras, falta de fusão e nem descontinuidades na raiz.

A literatura recomenda que um passe de raiz deve ter entre 4 e $6 \mathrm{~mm}$ de altura, não obstante, isso depende muito da configuração da junta, chanfro estreito, abertura da raiz e/ou tamanho do nariz, condições estas que definem a altura final do passe de raiz. Na Fig. 2.10, mostra-se um passe de raiz com espessura de $5,1 \mathrm{~mm}$, mas sem detalhes do formato da junta [42].

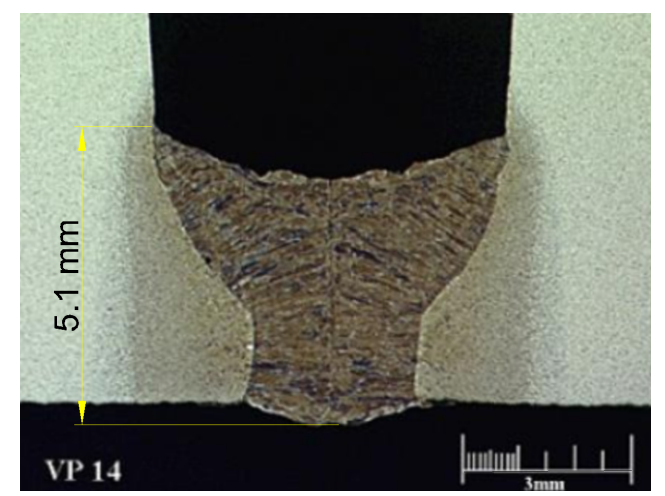

Figura 2.10. Espessura de solda em passe de raiz, modificado Barbosa [43]. 
De fato, nas pesquisas realizadas em laboratórios, a forma de encontrar penetração total em um formato de junta selecionado ocorre executando-se testes de tentativa e erro, considerando parâmetros de soldagem e configuração das juntas, uma vez após a soldagem a penetração total não conseguida se alteram os parâmetros de soldagem ou também as medidas da junta, até que a penetração total seja atingida. Estas metodologias são explicadas a seguir e representada nas Fig. 2.11. Nestes exemplos é apresentado uma junta de Topo em "V" considerando um tamanho de nariz, que pode também não ser considerado [42].

Considerando uma junta de topo sem abertura de raiz: neste caso é escolhido um conjunto de parâmetros para realizar o cordão de solda. Se a penetração total não é conseguida, então modificam-se os parâmetros de soldagem mantendo a espessura de nariz ou, também, pode-se diminuir a espessura de nariz mantendo-se os parâmetros de soldagem (Fig. 2.11).
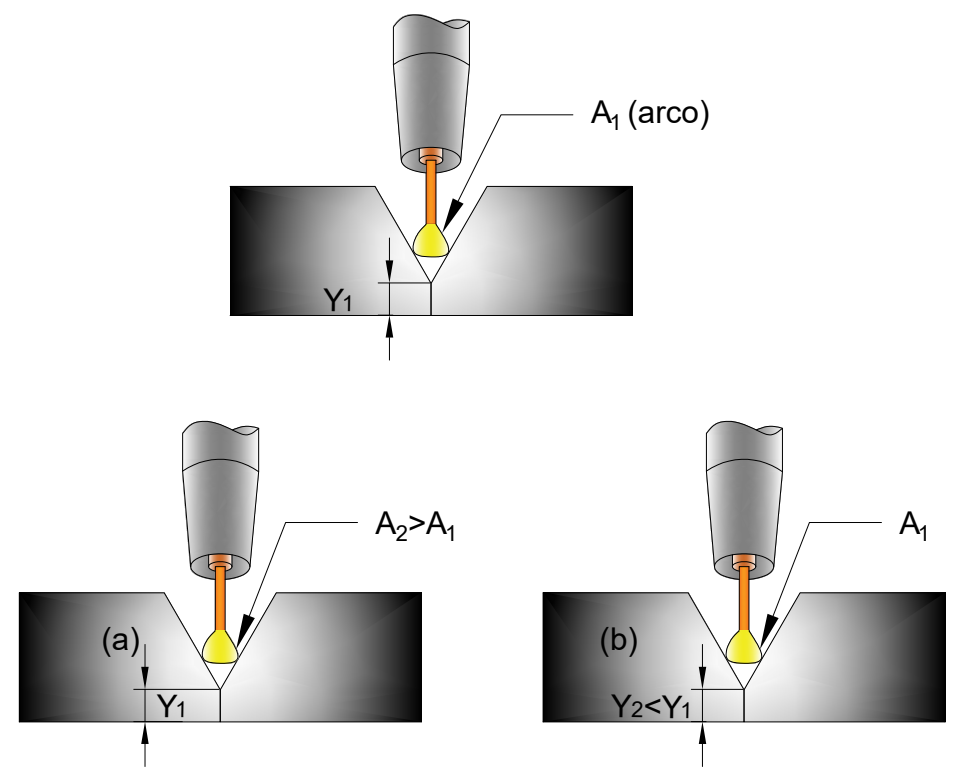

Figura 2.11. Representação da forma prática para obter penetração em junta de topo sem abertura de raiz, modificando: (a) parâmetros de soldagem e (b) espessura do nariz. (Modificado de Aures) [42].

\subsubsection{Descontinuidades Apresentadas em Passe de Raiz}

No processo de soldagem descontinuidades como poros, trincas, falta de fusão, entre outras, acontecem em função de diversos fatores. Assim, uma solidificação rápida pode levar à formação de poros e até mesmo dar origem a descontinuidade conhecida por cavidade alongada. A baixa energia de soldagem pode incidir em falta de fusão devido a pouca penetração, e o excesso de energia pode gerar cavidade na margem da solda ocasionando a descontinuidade conhecida por mordedura [5]. 
Portanto, descontinuidades relativas ao formato da penetração da raiz decorrem, os fatores presentes na soldagem como: abertura da junta; ângulo do chanfro; dimensões da face (nariz) da raiz; ângulo da tocha em relação à direção de soldagem; velocidade de soldagem; aporte térmico; manejo da tocha; instabilidade do arco; falta de proteção gasosa; desempenho inadequado dos equipamentos; entre outros [44].

Segundo Cantrell [44] a velocidade de soldagem alta causa o efeito de desvio do arco em direção à borda da poça de fusão e provoca pouca penetração da raiz. Baixa velocidade elimina este efeito de desvio do arco, com excesso de contorno do reforço da raiz. A Tabela. 2.1 apresenta as descontinuidades de solda mais usuais na deposição de passe de raiz.

Tabela 2.1. Descontinuidades usualmente apresentadas em passe de raiz $[45][46]$.

\begin{tabular}{|c|c|c|c|c|}
\hline $\begin{array}{l}\text { Fescontinuidade } \\
\text { ou penetração }\end{array}$ & Imagem \\
\hline Mordeduras & Trincas & & \\
\hline Excesso de \\
respingos
\end{tabular}

A inspeção visual é muito empregada como critério primeiro ao julgar a qualidade de um cordão de solda diante da ausência de mordeduras, observa-se o ângulo de molhamento, altura do reforço em função da largura do cordão como critério para julgar a energia de soldagem bem como a taxa de deposição de arame [47]. 


\subsection{SOLDAGEM DE TUBOS}

A soldagem de tubos foi desenvolvida no início da década de 1960 pelas indústrias aeroespacial e de energia nuclear, com o propósito de fornecer as condições básicas para fabricação de componentes altamente confiáveis [48] [49] [50]. O primeiro sistema de soldagem orbital foi um mecanismo de rotação de um eletrodo de tungstênio que fez um arco em torno da junta de solda do tubo. O sistema foi apoiado por um sistema de controle para todo o processo pelo qual obteve resultado mais preciso e confiável que a solda manual [51].

No começo dos anos 1980, tornou-se prática de soldagem orbital para muitas indústrias, graças ao desenvolvimento de sistemas de combinação de potência, de alimentação/controle, reduzindo o tamanho do equipamento. No final de 1990, a melhoria da tecnologia de microprocessador leva a soldagem orbital para a posição de um método econômico e predileto de fazer conexões fornecendo mais opções de soldagem para soldadores de diferentes níveis de habilidade [50].

Na contemporaneidade, a soldagem orbital é um dos principais métodos aplicados em quase todos os setores, como alimentos, laticínios, bebidas, energia, química, petróleo e gás, papel e celulose, etc [52]. A soldagem das linhas de dutos é uma solda circunferencial dos tubos e acessórios, sendo executadas em sua maioria, no campo. No entanto, em alguns países em desenvolvimento, este método esta sendo atualizado para atender aos requisitos de soldabilidade de novos materiais e as crescentes necessidades de aumento da produtividade.

Tradicionalmente os processos utilizados na soldagem de tubulações e aceitos pela norma API 1104 são: processo SMAW soldagem com eletrodo revestido que leva a baixos níveis de eficiência (ver Fig. 2.12a) as taxas de produtividade e qualidade só se incrementaram com a mecanização da soldagem orbital (ver Fig. 2.12b). A mecanização da soldagem demanda utilização de processos de soldagem automatizáveis, sendo mais adequados os processos: GTAW (Gas Tungsten Arc Welding), conhecido como processo TIG; processo GMAW (Gas Metal Arc Welding), o híbrido laser HLAW (Hybrid Laser Arc Welding) e o processo FCAW (Flux Cored Arc Welding), que é a soldagem com arame tubular. Porém, o ambiente de trabalho rever da soldagem orbital e os elevados custos de operação e manutenção limitam a utilização de processos mais sofisticados, sendo assim os processos SMAW/GMAW os mais utilizados.

O método tradicional de soldagem circunferêncial de tubos utilizados principalmente para a distribuição de gás e óleo (como é mostrado na Fig. 2.12a), é realizado com o processo manual SMAW utilizando eletrodos revestidos, principalmente por sua versatilidade. No entanto, com a adoção de aços de alta resistência, a reduzida tenacidade e os elevados teores de hidrogênio no metal depositado por eletrodos revestidos celulósicos, os quais podem chegar a níveis de $0,5 \mathrm{ml} / \mathrm{g}$, 
este tipo de consumível se torna pouco atraente, uma vez que esta combinação poderá levar a formação de trincas na zona termicamente afetada [53].
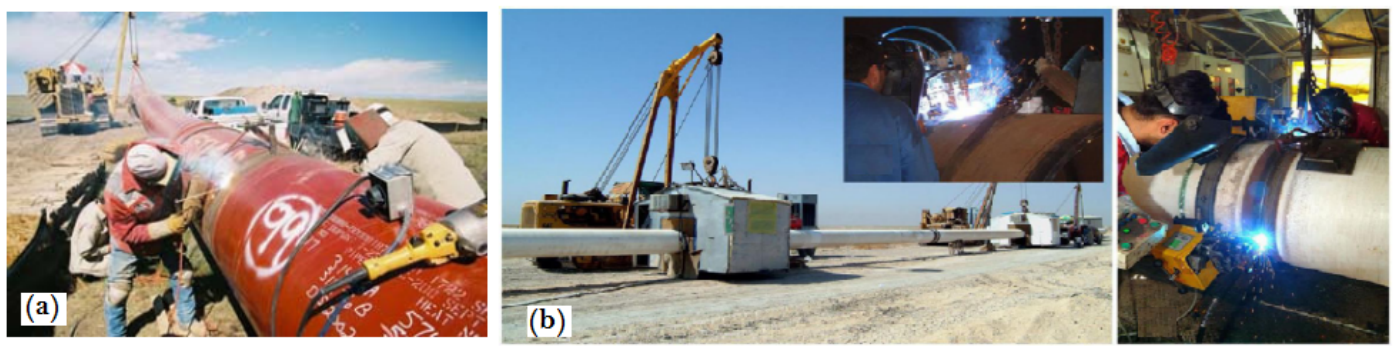

Figura 2.12. Soldagem Orbital: (a) Manual, (b) Mecanizada [54]

A soldagem circunferencial pode ser realizada com os tubos nas posições: $1 \mathrm{G}$ (posição plana, feita no lado superior em que a face da solda é aproximadamente horizontal), ou que a tocha de soldagem pode se movimentar ao redor do tubo, seguindo trajetórias diferentes de acordo com sua posição $2 \mathrm{G}$ (horizontal), 5G (sobre cabeça), 6G (com peca a ser soldada (tubo) em $45^{\circ}$ ); como é representado na Fig. 2.13. Neste trabalho, os testes de soldagem serão realizados na posição $5 \mathrm{G}$, na qual pode ser bem definida a soldagem nas posições plana, vertical e sobre-cabeça.

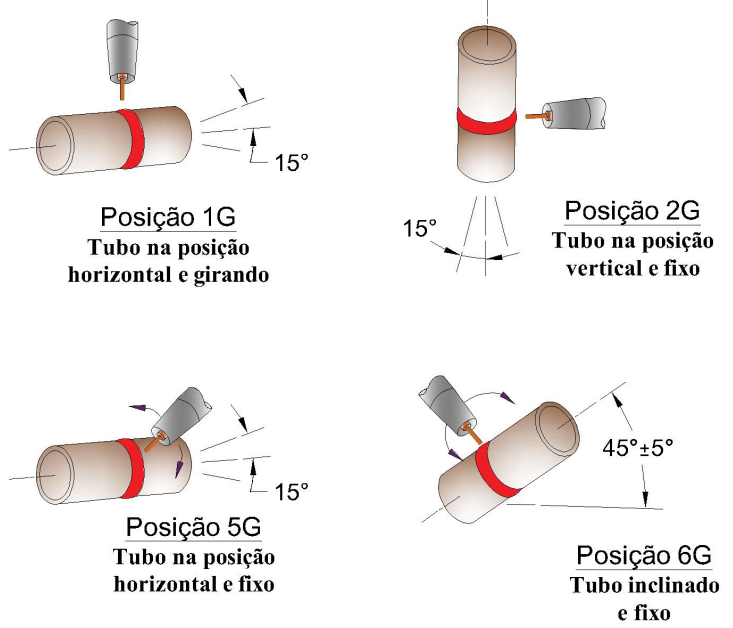

Figura 2.13. Posicionamento dos tubos para realização da soldagem circunferencial (Modificado de AWS [55]).

Quanto a união de tubos, ela é efetuada por soldagem mecânica ou automatizada, duas diferentes progressões de soldagem podem ser usadas quando o tubo está na posição 5G: soldagem descendente e soldagem ascendente. A seleção destas progressões não é afetada pelo diâmetro do tubo, é dependente de outros fatores como da espessura da parede, das ligas do tubo, do equipamento de soldagem e/ou do processo de soldagem. Independente do método a ser usado, o tubo inicialmente deve ser ponteado para logo poder ser soldado junto ou para manter a distância de separação ou o encosto uniforme entre eles [56]. 
Quando o tubo esta na posição $5 \mathrm{G}$ a geometria do tubo torna complicado o processo de soldagem porque este deve ser realizado em quatro posições diferentes, divididos em quatro zonas: posição plana $\left(315^{\circ}-45^{\circ}\right)$, posição vertical descendente $\left(45^{\circ}-135^{\circ}\right)$, sobre cabeça $\left(135^{\circ}-225^{\circ}\right)$, e posição vertical ascendente $\left(225^{\circ}-315^{\circ}\right)$, dependendo das mudanças de posição durante a soldagem circunferencial, refletidas no destacamento da gota, as variáveis podem ser alteradas ou modificadas para evitar o escorrimento do metal líquido da poça de fusão, o que comprometeria a qualidade da solda.

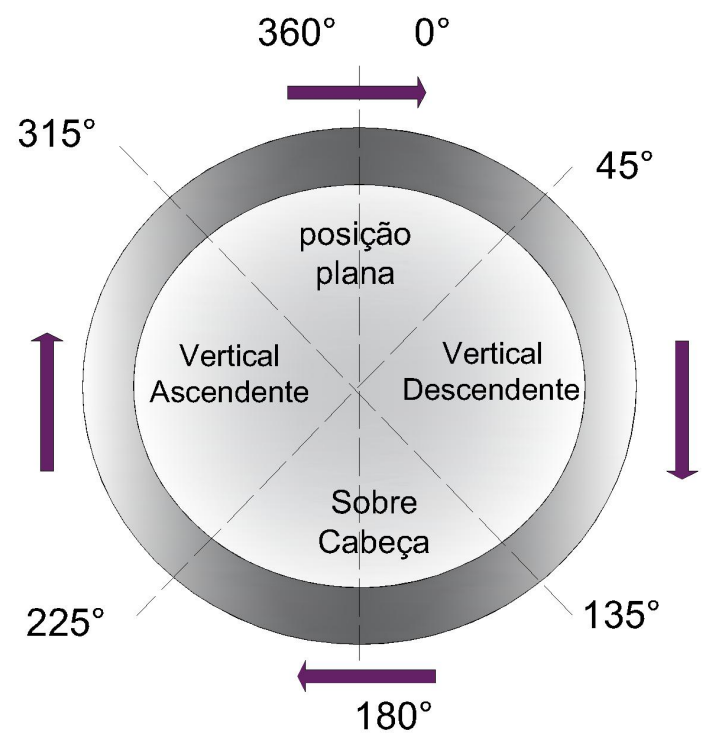

Figura 2.14. Posições de soldagem adoptadas no tubo [57].

Considerando a progressão descendente, a união dos tubos é realizada em duas etapas: a primeira etapa começa no ponto mais alto do tubo (12 horas ou $0^{\circ}$ ), na posição plana, e termina no ponto mais baixo (6 horas ou $\left.180^{\circ}\right)$ ), na posição sobrecabeça, por um lado, e na segunda etapa o processo é repetido pelo lado oposto do tubo. Durante a realização da solda, a tocha se desloca ao redor dos tubos tomando diferentes posições neste percurso, sendo as posições mais críticas ou diferenciadas as posições plana $\left(0^{\circ}\right)$, vertical $\left(90^{\circ}\right)$ e sobrecabeça $\left(180^{\circ}\right)$. Neste caso, considera-se que as mesmas condições, especificamente o posicionamento ou angulação da tocha em relação ao tubo, permanece constante ao longo da soldagem. A Fig. 2.15, representa uma soldagem na progressão descendente, em $180^{\circ}$, com as diferentes posições da tocha durante esta soldagem, passando pelas posições: plana, vertical e sobrecabeça. Cabe ressaltar que em todo momento a tocha se desloca sobre um eixo que passa pelo seu próprio eixo longitudinal e que corta o eixo central do tubo. 


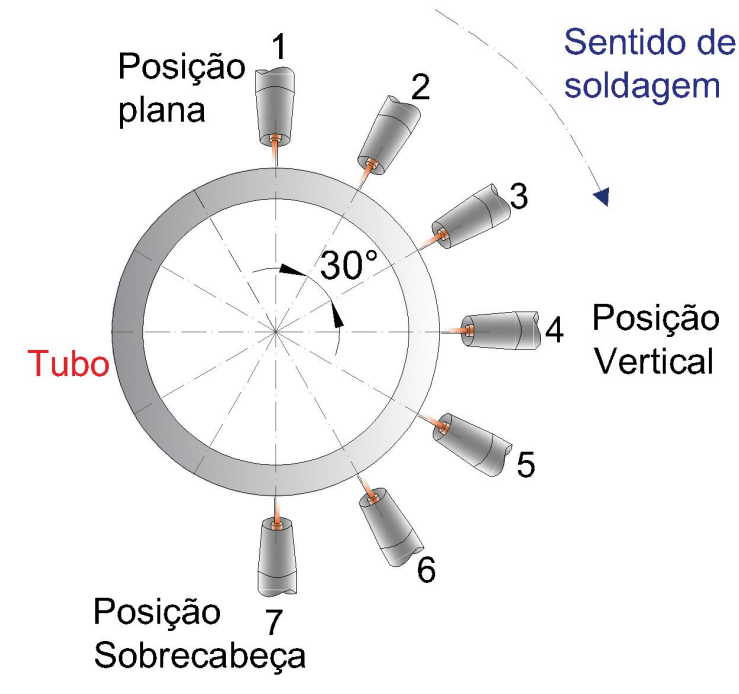

Figura 2.15. Representação de uma soldagem na progressão descendente mostrando o posicionamento da tocha ao longo da soldagem em $180^{\circ}$.

Por conseguinte, para obter resultados desejados é necessário um controle preciso do ângulo da tocha no plano de deslocamento durante o processo de soldagem. A razão é a exigência de puxar ou empurrar a poça de soldagem, e na direção perpendicular ao movimento, para corrigir a trajectória e para controlar o stick-out. Além disso, o movimento ângular lateral em relação ao chanfro é um fator importante na soldagem de tubos no sentido ascendente ou descendente. A Fig. 2.16 mostra cinco graus de liberdade no manipulador para obter os possíveis movimentos a serem executados pela mão de um soldador humano [58].

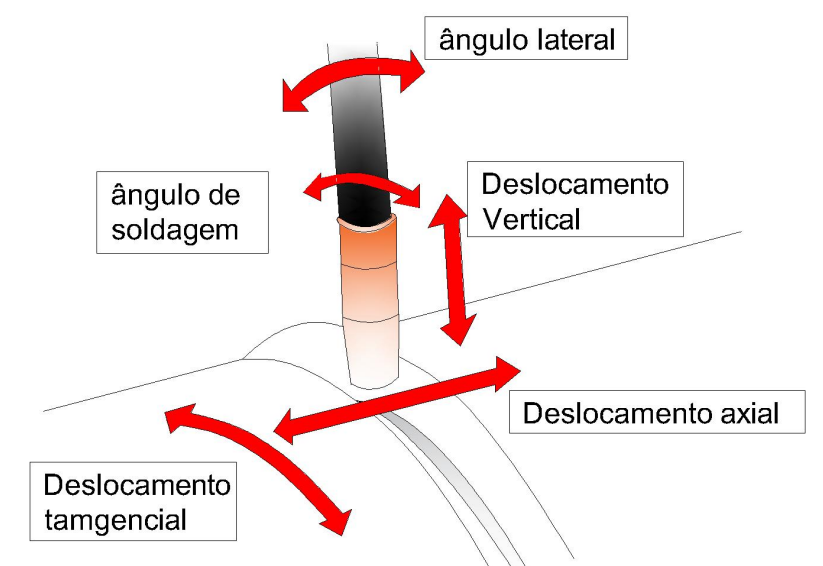

Figura 2.16. Tocha de soldagem com os graus de liberdade (Modificado de Filho) [58]. 


\subsubsection{Manipuladores de soldagem orbital}

As dificuldades no controle do deslocamento da tocha no processo de soldagem automática de tubos em campo, necessita que os manipuladores mecânicos sejam portáteis, acessíveis que permitam o controle do arco, velocidade de deslocamento, fácil montagem boa velocidade de soldagem e ocasione menor distorção [59]. Estes equipamentos na maioria tem 3 ou 4 graus de liberdade o que limita, em algumas situações, o correto posicionamento da tocha de soldagem.

Geralmente, os sistemas de cabeçotes abertos são usados para soldagem de tubos de grandes diâmetros e espessuras de parede (acima de 170 milímetros) sendo considerados de função completa [60], consiste em um conjunto de mecanismo como: bandas ou cadeias, fonte de alimentação, alimentador de arame, um controlador programável, gás de proteção e refrigerante. Bandas ou cadeias é um dispositivo conectado ao tubo para mover a cabeça ao redor da articulação. O controlador pode ser integrado à fonte de alimentação e cabo de fornecimento de energia. Os cabeçotes de soldagem são montados em bandas ou cadeias e percorre a circunferência do tubo ao longo de uma faixa. Na soldagem do tubo de parede fina, este cabeçote de soldagem precisa de um sistema de refrigeração de água para reduzir a entrada de calor. A principal aplicação deste sistema de soldagem é em dutos terrestres [61].

Por exemplo: com o processo FCAW se tem um manipulador orbital utilizado em diferentes aplicações como a construção naval, a soldagem de tubulação de alta pressão em usinas de energia ou duplex, montagens de tubulação de aço inoxidável para a produção offshore de gás, fábrica de produtos químicos/construção da refinaria e transporte. Este processo tem sido utilizado em união de tubos com grande diâmetro e espessura da parede, com uma taxa de deposição de 3,63 $\mathrm{kg} / \mathrm{h}$. A Fig.2.17a, mostra o uso deste processo em um tubo utilizado em transporte de gás [62].

Por outro lado, na WERC (Welding Engineering Center) da Universidade de Cranfield, desenvolveu-se um sistema que reduz significativamente o número de passes de enchimento, melhora a produtividade. (montam-se de duplo arame em um único cabeçote). A melhoria consiste em reduzir a distância entre dois fios usando gás de proteção compartilhado e poça de fusão, chamado de processo de "dupla-tandem". Sendo um método eficiente no passe de enchimento, fazendo um custo baixo de soldagem, este processo pode ser usado em aplicações onshore e Offshore em soldagem de gasodutos [63]. Este dispositivo é mostrado na Fig. 2.17b.

O Laser híbrido/GMAW apresenta um processo de arco que provoca a diminuição da superfície da poça fundida, aumentando a profundidade de penetração determinada pela potência do laser. A largura da solda é determinada principalmente pelo arco, em particular, pela tensão do arco. Em contraste com o processo de feixe de laser puro, podendo obter aumento na de velocidade de soldagem em até $100 \%$ com uma potência de feixe laser constante. A Fig. 2.17c, 
é um cabeçote de soldagem equipada com 3 graus de liberdade, tendo uma soldagem híbrida para passe de raiz, e o segundo arco da tocha integrado para soldagem do passe de enchimento durante o movimento vertical-descendente da soldagem [64].

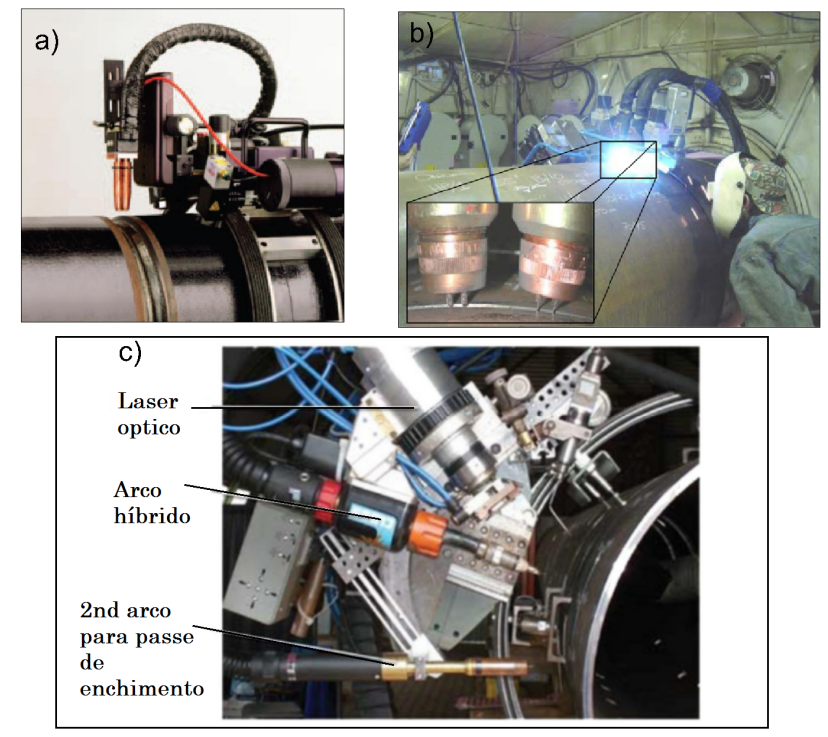

Figura 2.17. (a) Orbital FCAW para soldagem de tubos de grande diâmetro [65] , (b) Cabeçotes para soldagem orbital automatizada com duas tochas [66], (c) equipamento híbrido para soldagem do passe de raiz [67].

No laboratório de robótica, soldagem e simulação (LRSS) da UFMG - parceria com uma empresa privada- desenvolveu-se um manipulador para a soldagem orbital de tubos. O robô é composto por um trator pequeno pressionado contra o tubo por meio de correntes, que são utilizados pelo robô para mover-se sobre e ao redor do tubo. Os parâmetros de soldagem são controlados de modo a otimizar a solda. Quatro destes parâmetros são controlados pelos quatro graus de liberdade do robô: velocidade de soldagem; o ângulo da tocha; stick out e alinhamento com o cordão depositado. Dois parâmetros a mais são controlados por uma interface especialmente concebido com a fonte de solda de baixo custo. Tendo como objetivo final obter um manipulador capaz e de baixo custo [57] mostrado na Fig. 2.18(b).

No mercado nacional, tem-se equipamentos para soldagem orbital convencional, como o Tartilope V4 que foi desenvolvido em LABSOLDA (UFSC), sendo projetado para ser aplicado na automação do processo de soldagem GMAW em posições e situações de extrema dificuldade no qual necessitam de maior número de graus de liberdade, em especial para a união de dutos, que abrange quatro posições diferentes de soldagem e no revestimento de tubos de caldeira [68]. Este é um manipulador robótico que possui quatro graus de liberdade, sendo que três deles são lineares e um rotacional, posicionado na ponta do "braço" onde é fixada a tocha de soldagem mostrado na fig. 2.18(a), este dispositivo também é usado em Laprosolda (UFU) e em GRACO $(\mathrm{UnB})$. 


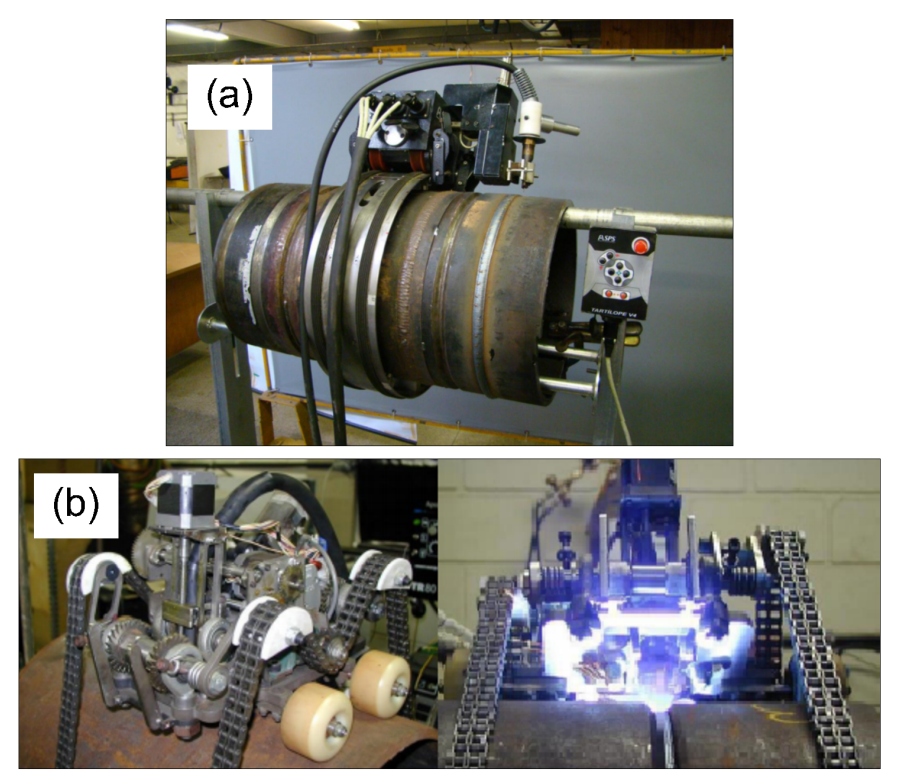

Figura 2.18. (a)Suporte de dutos e Tartilope V4 para testes de soldagem orbital [69], (b)Robô de soldagem utilizado em união de tubos [57].

Considerando toda a experiência já adquirida, a tecnologia de soldagem de tubulações encontra-se em constante desenvolvimento, sempre atualizando-se afim de solucionar os requisitos de soldabilidade de novos materiais, e as crescentes necessidades de aumento da produtividade [9]. Os metais de adição empregados no caso de GMAW e FCAW são geralmente arames sólidos ou tubulares, com diâmetros variando em torno de 0,9 a 1,2 mm. Nessa situação, preferese adotar um arame de menor resistência mecânica e maior tenacidade para a deposição do passe de raiz. Em seguida, seleciona-se outro arame para o enchimento e acabamento de acordo com os valores mecânicos do tubo que está sendo soldado. O gás de proteção normalmente utilizado é o gás carbônico puro $\left(\mathrm{CO}_{2}\right)$. No entanto, combinações Argônio/ $\mathrm{CO}_{2}(75 \% / 25 \%)$ podem ser utilizadas para a deposição do passe de raiz e do passe de cobertura, nos quais existe uma maior preocupação com a configuração geométrica do cordão de solda [9].

\subsection{PLANEJAMENTO EXPERIMENTAL}

Frequentemente, a qualidade de uma junta soldada é diretamente influenciada pelos parâmetros de entrada do processo de soldagem, fazendo com que seja considerado um processo multi-entrada e multi-saida. Um problema comum enfrentado pelo soldador é o controle dos parâmetros de entrada para obter uma junta soldada com a geometria do cordão requerida, com qualidade da solda na companhia de mínima tensão residual e distorção. Para fazer isso, é necessário utilizar tempo para testes, com os parâmetros de entrada escolhidos pela experiência do engenheiro ou operador do equipamento de soldagem. Portanto, as soldas são examinadas para determinar se atingem as especificações ou não, o que determinará a escolha ou não dos 
parâmetros de soldagem que produzam uma junta que atenda os requerimentos necessários.

Desta forma, para resolver esse problema faz-se uso do planejamento experimental para otimizar o número de ensaios a ser realizado com confiabilidade estatística, sendo esse número adequado para minimizar os erros experimentais (aleatórios), contribuindo, também, na obtenção de viabilidade econômica e prática da experimentação. Sendo aplicados para relacionar as variáveis de saída definidas através de modelos matemáticos para definir a relação entre os parâmetros de entrada com as variáveis de saída.

Neste trabalho, além da função de reduzir o número de ensaios, garantir confiabilidade e analisar influência de fatores sobre respostas, os dois planejamentos a serem utilizados como: metodologia de superfície de resposta "MSR" com a aplicação de um arranjo composto central com o objetivo de ajustar os modelos de superfície de resposta de segunda ordem, logo a utilização do método Desirability para tratar a otimização simultânea dos modelos de múltiplas respostas. Salientando que estas ferramentas estatísticas serão usadas na segunda etapa deste trabalho.

\subsubsection{Metodologia de Superfície de Resposta}

A Metodologia de Superfície de Resposta (MSR), segundo Montgomery [70], é uma coleção de ferramentas matemáticas e estatísticas empregadas para a modelagem e análise de problemas que a resposta de interesse é influenciada por diversas variáveis. Para a maioria dos problemas verifica-se as relações entre a resposta e as variáveis independentes conhecidas. Por conseguinte, é preciso encontrar uma aproximação razoável para a verdadeira relação entre $(Y)$ e o conjunto de variáveis independentes $(x)$. Geralmente, é empregado um polinômio de ordem baixa em algumas regiões de interesse. Se a resposta for bem modelada por uma função linear das variáveis independentes a função de aproximação será o modelo de primeira ordem, conforme a Eq 2.1

$$
Y=\beta_{0}+\beta_{1} x_{1}+\beta_{2} x_{2}+\cdots+\beta_{k} x_{k}+\varepsilon
$$

Onde $\beta$ é o coeficiente polinomial, $K=p$ (número de parâmetros) e $\varepsilon$ é o erro. Entretanto, se existir curvatura no sistema, a função de aproximação mais usada será um polinômio de ordem superior, como o modelo de segunda ordem apresentado pela Eq 2.2.

$$
\hat{\sigma}=\beta_{0}+\sum_{i=1}^{k} \beta_{i} x_{i}+\sum_{i=1}^{k} \beta_{i i} x_{i}^{2}+\sum_{i<j} \sum \beta_{i i} x_{i} x_{j}+\varepsilon
$$

Segundo Box e Draper [71] os dois modelos referidos: primeira ordem, para sistemas sem curvatura, e de segunda ordem, para sistemas com curvatura, conseguem representar quase todos os problemas relacionados a seperfície de respostas. 
Montgomery [70] considera improvável que um modelo polinomial aproxime-se de um modelo real para todo o espaço experimental coberto para as variáveis independentes. Para uma região específica a aproximação tem-se mostrado eficiente.

O método dos mínimos quadrados ordinários (Ordinary Least Squares - OLS) é usado para estimar os parâmetros $\beta$ do modelo polinomial, que em forma matricial, podem ser representados pela Eq 2.3:

$$
\hat{\beta}=\left(X^{T} X\right)^{-1} X^{T} X
$$

Onde: $X$ é a matriz de fatores codificados.

A Metodologia de Superfície de Respostas tem como finalidade principal determinar as condições operacionais ótimas para o sistema, ou determinar uma região do espaço fatorial em que as especificações operacionais sejam satisfeitas. O termo "ótimo" na metodologia é empregado em sentido especial. Os procedimentos de "subida" da metodologia garantem convergência para somente um ótimo local.

\subsubsection{Arranjo Composto Central}

O arranjo do composto central (Box-Wilson Central Composite Design - CCD) é usado para ajustar um modelo de superfície de resposta de segunda ordem. É um arranjo largamente utilizado na prática, por conta da sua relativa eficiência com respeito ao número de amostras requeridas.

O $C C D$ é uma matriz formada por três grupos distintos de elementos experimentais: um fatorial completo ou fracionado; um conjunto de pontos centrais e, adicionalmente, um grupo de níveis extras denominados Pontos Axiais. Se a distância entre o centro do arranjo e o ponto fatorial $(+1 ;-1)$ for aproximadamente 1 (em módulo), a distância do centro ao ponto axial será maior que a unidade. Esta distância comumente representada por $\alpha$, depende de certas propriedades desejadas para o experimento e do número de fatores envolvidos [70], tal como se ilustra na Fig. 2.19. O número de pontos axiais em um $C C D$ é igual ao dobro do número de fatores e representam seus valores extremos. Em função de sua localização, podem ser circunscritos, inscritos ou de face centrada.

Para manter a rotacionalidade de um arranjo, o valor de $\alpha$ depende do número de experimentos $(k)$ da porção fatorial do $C C D$. Segundo Box e Drapper [71] pela eq.2.4 :

$$
\alpha=(\text { número de experimentos })^{\frac{1}{4}}=\left(2^{k}\right)^{\frac{1}{4}}
$$




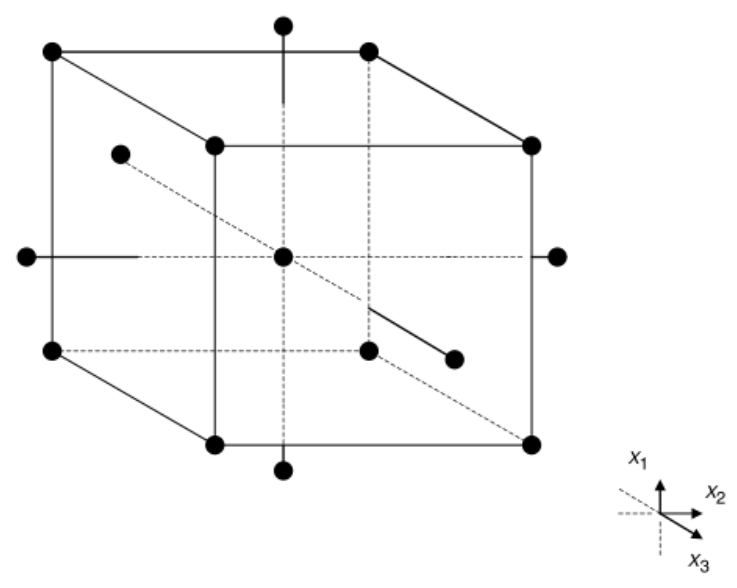

Figura 2.19. $C C D$ para três fatores

O cubo face centrada não requer muitos pontos centrais como o $C C D$ esférico. Na prática, 2 ou 3 pontos são suficientes para possibilitar boa variância de predição em toda a região experimental. Isto pode ser notado porque as vezes as ocorrências centrais deverão ser empregadas para dar um razoável cálculo de erro experimental.

Este modelo é adequado, uma vez que muitos processos podem ser aproximados por uma expansão em série de Taylor, truncada em um termo quadrático.

\subsubsection{O método Desirability}

Encontrar uma condição ótima para operação de um processo que o viabilize ou produza resultados com consideráveis melhorias, é o objetivo fundamental da metodologia de superfície de resposta. Para alcançar tais resultados, diversos algoritmos de modelagem são utilizados para estabelecer funções de transferência entre os dados e as variáveis de controle experimentais, viabilizando a determinação do ponto de ótimo. A uma parte da totalidade das pesquisas em otimização que utilizam alguma metodologia experimental para múltiplas respostas, trata as respostas de forma isolada na fase de construção dos modelos de regressão. Este processo pode ser ineficiente, especialmente se as respostas forem fortemente correlacionadas.

Com isso, se tem o método Desirability - expressão não traduzida por entender-se não ser apropriado, pois é um algoritmo criado originalmente por Harrington [72] e, posteriormente aprimorado por Derringer e Suich [73], para tratar da otimização simultânea dos modelos de múltiplas respostas.

Segundo Van Gyseghem [74], o Desirability é um método multicritério capaz de avaliar um conjunto de respostas simultaneamente, e que permite a determinação do conjunto de condições mais desejável para as propriedades estudadas. 
Utilizando-se MSR e OLS (Mínimos Quadrados Ordinários ou Ordinary Least Square), estabelece-se um relacionamento entre as respostas e as variáveis independentes, utilizandose a formulação unilateral ou bilateral de Harrington [72] e Derringer e Suich [73], cada uma das respostas do conjunto original é transformada, tal que $d_{i}$ pertença ao intervalo $0 \leq d_{i} \leq 1$. $\mathrm{O}$ valor de $d_{i}$ aumenta quando a $i$-ésima resposta se aproxima dos limites impostos.

A Eq.2.5, abaixo, é utilizada para encontrar o índice global $D$, a partir da combinação de cada uma das respostas transformadas por meio de uma média geométrica.

$$
D=\left(d_{1}\left(Y_{1}\right) \times d_{2}\left(Y_{2}\right) \times \ldots d_{k}\left(Y_{k}\right)\right)^{\frac{1}{k}}
$$

Como resultante da média geométrica representada pela Eq.2.5, o valor de $D$ avalia de maneira geral os níveis do conjunto combinado de respostas. É um índice também pertencente ao intervalo $[0,1]$ e será maximizado quando todas as respostas se aproximarem o máximo possível de suas especificações. Osborne et al. [75] e Rossi [76] afirmaram que, quanto mais próximo de 1 estiver $D$, mais próximas as respostas originais estarão dos seus respectivos limites de especificação. O ponto de ótimo geral do sistema é o ponto de ótimo alcançado pela maximização da média geométrica (Eq.2.5), calculada a partir das funções Desirability individuais.

A utilização da média geométrica tem a vantagem de fazer com que a solução global seja alcançada de maneira balanceada, permitindo que todas as respostas atinjam os valores esperados e forçando o algoritmo a se aproximar das especificações impostas. Caso isto não seja possível, o algoritmo retorna a uma solução inviável (e indesejável) para o problema.

Na essência, este método condensa um problema de otimização multivariada em um problema univariado. A desvantagem, segundo Khuri e Conlon [77], é que nesta transformação, a estrutura de variância-covariância das respostas é totalmente ignorada.

O algoritmo de Derringer e Suich [73] depende do tipo de otimização desejada para a resposta (maximização, normalização ou minimização), dos limites (valores desejados) e das respectivas importâncias de cada resposta. A Tabela 2.2 apresenta as principais características dos diferentes tipos de otimização utilizando este método.

De acordo com Wu [79], quando se deseja a maximização de uma resposta, a fórmula de transformação empregada é:

$$
d_{i}=\left\{\begin{array}{cc}
0 & \hat{Y}_{i}<L S L \\
{\left[\frac{\hat{Y}_{i}-L i}{T i-L i}\right]^{R}} & L i \leq \hat{Y}_{i} \leq T i \\
1 & \hat{Y}_{i}>T i
\end{array}\right.
$$

Onde: $L i$ e $T i$ são, respectivamente, o maior e o menor valor aceitáveis para a $i$-ésima 
Tabela 2.2. Objetivos de otimização do método de Derringer [78]

\begin{tabular}{|c|c|c|}
\hline Objetivo & Características & Representação Esquemática \\
\hline Minimizar & $\begin{array}{l}\text { O valor da função Desirability aumenta } \\
\text { enquanto que o valor da resposta } \\
\text { original se aproxima de um valor alvo } \\
\text { mínimo. Abaixo do alvo, } \mathrm{d}=1 \text {; acima } \\
\text { do limite superior, } \mathrm{d}=0 \text {. }\end{array}$ & $\overbrace{\text { Limite Superior }}^{\text {Peso }=0.1}$ \\
\hline Normalizar & $\begin{array}{l}\text { Quando a resposta se move em direção } \\
\text { ao alvo, o valor da função desirability } \\
\text { aumenta. Acima ou abaixo dos limites, } \\
\qquad \mathrm{d}=0 \text {; no alvo } \mathrm{d}=1 .\end{array}$ & Limite Inferior \\
\hline maximizar & $\begin{array}{l}\text { O valor da função desirability aumenta } \\
\text { quando o valor da resposta aumenta. } \\
\text { Abaixo do limite inferior, } \mathrm{d}=0 \text {; acima } \\
\text { do alvo, } \mathrm{d}=1 \text {. }\end{array}$ & Limite Inferior \\
\hline
\end{tabular}

resposta.

O valor de $R$ na Eq. 2.6, indica a preponderância dos limites. Valores maiores que a unidade devem ser usados quando a resposta cresce rapidamente acima de $L_{i}$. Portanto, $d_{i}$ aumenta vagarosamente, enquanto o valor da resposta vai sendo maximizado. Logo, para se maximizar $D$, a $i$-ésima resposta deve ser bem maior que $L_{i}$. Pode-se escolher $R<1$, quando não for crítico encontrar valores para a resposta abaixo dos limites fixados.

A Minimização de $\hat{Y}_{i}$ é equivalente a Maximização de $-\hat{Y}_{i} \quad$ [73].

Há casos em que o objetivo é atingir um valor alvo, a formulação de transformação deixa de ser unilateral e passa a ser bilateral. A formulação bilateral, representada pela Eq. 2.7, ocorre quando a resposta de interesse possui duas restrições: uma de máximo e outra de mínimo.

$$
d_{i}=\left\{\begin{array}{cl}
0 & \hat{Y}_{i}<\operatorname{Liou} \hat{Y}_{i}>H i \\
{\left[\frac{H i-\hat{Y}_{i}}{H i-T i}\right]^{R}} & T i \leq \hat{Y}_{i} \leq H i \\
{\left[\frac{\hat{Y}_{i}-L i}{T i-L i}\right]^{R}} & L i \leq \hat{Y}_{i} \leq T i
\end{array}\right.
$$




\subsection{CÁLCULO DA POTÊNCIA DE SOLDAGEM}

A designação da potência de soldagem é o produto da tensão pela corrente. Acontece, que frequentemente uma devida interpretação não é dada a esta definição. Ocasionalmente é realizada a leitura da tensão média e da corrente média com isto o produto é denominado de potência. Mesmo assim não é correto pois o produto das médias de duas variáveis é diferente da média dos produtos de valores que ocorre com certa frequência das variáveis envolvidas. Deste modo, a eq. 2.8 é errada. Outro critério, que por vezes também é adotado, é o produto da tensão eficaz pela corrente eficaz, conforme a eq. 2.9, o que para um processo submetido a situações dinâmicas (no caso de soldagem em pulsada), também é errôneo. Esta Eq. 2.10 somente é válida quando a carga elétrica obedecer estritamente à lei de Ohm. O desvio do arco em relação à lei de Ohm é tanto maior quanto maior for a diferença entre os patamares dos valores de corrente, pois a componente da força contra-eletromotriz no arco se torna altamente pronunciada [80].

$$
\begin{gathered}
P=U_{\text {méd }} \times I_{\text {méd }} \\
P=U_{\text {eficaz }} \times I_{\text {eficaz }} \\
P=\frac{\sum_{i=1}^{n} U_{i} \times I_{i}}{n}
\end{gathered}
$$

O cálculo que considera os valores pontuais de tensão e corrente, representado pela eq. 2.10, é o considerado correto [81] [82]. Todos os valores de potência apresentados na sequência foram calculados sobre essa equação que serão motivo de análise nos processo de soldagem Curto Circuito convencional e GMAW-CMT.

\subsection{REVISÃO DA LITERATURA ESPECIALIZADA}

\subsubsection{Pesquisas Desenvolvidas por Metodologias Experimentais}

Um dos objetivos do planejamento experimental é a otimização do número de ensaios a serem realizados. Como visto anteriormente, esse número deve ser adequado de modo a minimizar os erros experimentais (aleatórios), mas também deve contribuir para a viabilidade econômica e prática da experimentação. A seguir são apresentados as pesquisas desenvolvidas com a ajuda de planejamentos experimentais na aplicação da indústria. 
A metodologia de superfície de resposta (RSM) foi utilizada por Murugan e Parmar em 1994 [83] para estabelecer as relações quadráticas entre os parâmetros do processo de soldagem GMAW e a geometria do cordão em aço inoxidável.

No ano 2000 Gunaraj e Murugan [84] fizeram um desenvolvimento de modelos matemáticos na previsão e otimização do volume de um cordão de solda para um processo de arco submerso. Utilizando a metodologia de superfície de resposta com precisão de aproximadamente $98 \%$ de confiabilidade.

Rodrigues et al. em 2008 [85], desenvolveram um trabalho no qual fizeram uma análise e otimização dos parâmetros de soldagem: tensão, velocidade de alimentação do arame e distância bico de contato peça, em um processo com arame tubular com proteção gasosa, sobre a penetração e o índice de convexidade da solda. Por meio de técnicas estatísticas foi desenvolvido um modelamento matemático e posterior otimização das respostas. Em função dos resultados obtidos observou-se forte influência da velocidade de alimentação do arame no processo, seguido pela tensão e com menos intensidade pela distância bico de contato peça.

Paiva em 2010 [86], desenvolveu um método para otimização multiobjetiva, desenvolvido para o estudo do processo de soldagem FCAW (do inglês Flux Cored Arc Welding), utilizando arames tubulares baseado no conceito de erro quadrático médio multivariado, apresentando uma abordagem combinada da metodologia de superfície de resposta, projeto de experimentos e análise de componentes principais, na tentativa de localizar valores próximos a alvos específicos, para cada uma das características estudadas (Penetração, Taxa de deposição, Rendimento, Índice de convexidade e Diluição), considerando as variáveis de processo expressas em função da tensão (V), velocidade de alimentação do arame (Va) e da distância do bico de contato-peça (DBCP). Os resultados obtidos foram positivos na adequação desta proposta.

Lopera et al. em 2012 [87], fizeram um trabalho apresentando uma metodologia para modelar empiricamente o modo de transferência goticular projetada em processos de soldagem GMAW, utilizando algoritmos de processamento de imagens digitais e a metodologia de superfície de resposta. Modelos correspondentes ao tamanho e à frequência de destacamento das gotas são obtidos em relação as entradas de tensão e velocidade de alimentação do arame. As técnicas utilizadas na coleta dos dados e os modelos encontrados, validaram a metodologia proposta por apresentar uma correta representação do modo de transferência.

Xiong et al. em 2012 [88], fizeram a aplicação de uma rede neural e uma análise de regressão de segunda ordem para predizer a geometria da união na solda por arco elétrico. Desenvolveu-se uma série de experimentos mediante a aplicação de um desenho composto central. Os resultados demonstraram que não somente os modelos propostos podem predizer a largura e o reforço com uma precisão razoável do cordão, mas também o modelo de rede neural tem um melhor 
rendimento que o modelo de regressão de segunda ordem devido a sua grande capacidade de aproximar os processos não lineares.

Costa em 2013 [89], fez uma soldagem de dutos de aço ao carbono ABNT 1020 com 63 mm de diâmetro interno, 5,5 mm de espessura, utilizando o processo GMAW com transferência por curto circuito convencional com passe simples. Para o desenvolvimento do trabalho foi elaborado um planejamento com 16 ensaios para ambas direções de soldagem, por meio de um Planejamento Composto Central (PCC) de face cúbica, três fatores e dois blocos. Tendo como resultado uma maior penetração dos cordões soldados na direção ascendente. Nos cordões soldados na direção descendente observou-se um tendência maior ao escorrimento da poça de fusão na posição vertical e sobrecabeça. As soldas realizadas na direção ascendente aos ensaios descartados apresentaram defeitos como falta de material para enchimento do chanfro e perfuração da raiz com um arame ER70S-6 de 1,2 mm de diâmetro protegido com $\mathrm{Ar}+25 \% \mathrm{CO}_{2}$ com vazão de $15 \mathrm{l} / \mathrm{min}$.

Torres et al. em 2013 [90], desenvolveu uma metodologia para encontrar variáveis de entrada ideal em processos GMAW com arame tubular, que utiliza imagens obtidas através de uma câmera de alta velocidade com o objetivo de identificar os diferentes modos de transferência de metal e regiões de trabalho. Todos os modelos de geometria do cordão de solda foram encontrados utilizando a metodologia de superfície de resposta e a metodologia central composto. Critérios para a qualidade das juntas foram definidas a partir das respostas de superfícies e parâmetros de entrada ideais foram encontrados.

Silva e Marins em 2013 [91] apresentaram um trabalho de forma prática, a aplicação de técnica de otimização multi-objetivo da Pesquisa Operacional (PO) em problemas da área de Projeto e Análise de experimentos com múltiplas respostas, comparando-as com as técnicas tradicionalmente adotadas. Desse modo, foi aplicado e comparado o desempenho de um método de Aglutinação, utilizando um modelo de Programação por Compromisso (Compromise Programming - CP), com os resultados obtidos pelo método da função Desirability. Para esta comparação foram utilizados os dados dos artigos clássicos de Derringer e Suich e Khuri e Conlon. O resultado obtido com a aplicação da CP que utilizou a metaheurística evolucionária do software Optquest, foi superior ao do método da função Desirability. 


\subsubsection{Pesquisas em Juntas de Soldagem}

As juntas comumente utilizadas em estruturas de aço, chamadas de "metal de base", são a região entre duas peças que serão unidas e configuradas antes de serem soldadas. Elas têm grande influência na confiabilidade da junta de topo, de modo que a seleção de sua geometria deve ser efetuada de acordo com o tipo de aplicação. Portanto, dimensionar corretamente juntas soldadas sobre estruturas metálicas pode evitar falhas, eventualmente catastróficas, além, de reduzir significativamente custos e distorções.

Na presente seção, há uma apresentação de estudos realizados por diferentes pesquisadores no domínio da soldagem, em especial, pesquisas relacionadas em juntas de soldagem.

Balfour et al, em (2006) [92] desenvolveram um sensor de visão, usado para captar imagens a partir da junta de soldagem com uma abordagem universal, onde foi implementado um algoritmo robusto de análise destas imagens. Este sistema pode ser usado em processos de soldagem comumente usados, a aplicação específica deste trabalho envolve a implementação de um rosto de solda ou sensor de superfície superior, para medição do processo GTAW e automação baseada na detecção de recurso borda de uma imagem. O objetivo consiste em utilizar as medições geradas pelo algoritmo de processamento dentro de um sistema de controle de processo a base de realimentação.

Logo Koleva et al [93], em 2010 fizeram uma investigação dirigida á dependência das características de qualidade: larguras de soldagem exterior e interior (geometria da solda), a partir dos parâmetros do processo de arco orbital e as dimensões do tubo. No arco orbital, a largura e a forma das juntas soldadas dependem da posição espacial da solda além, dos parâmetros do processo e as dimensões da tubulação. Obtiveram uma junta soldada, mostrando claramente o segmento de concavidade, típico para parede lateral soldada, zonas de tubos em arco orbital com correntes relativamente altas e baixas velocidades de rotação do eletrodo.

Em 2011, Machado [94] desenvolveu um sistema de dimensionamento direcionado a engenheiros de soldagem e/ou projetistas de estruturas soldadas, tendo as opções existentes no projeto de juntas de filete, quando carregadas transversalmente, inclinadas, ou paralelamente ao eixo do cordão de solda. Esse efeito por meio da discussão dos aspectos fundamentais deste tipo de junta, fundamenta-se numa série de equações que permitem o dimensionamento da garganta, e exemplos utilizando metais base e consumíveis reais, Também investigou juntas de filetes soldadas sob conceitos da teoria da elasticidade e plasticidade localizada.

Meller et al, [69] fizeram uma metodologia de soldagem automatizada em processo GMAW, analisando dois tipos de arames, um maciço (ER70S-6) e outro tubular com o objetivo de procurar parâmetros de soldagem adequados para realizar os passes de preenchimento em uma junta 
com chanfro em "V", nas posições vertical ascendente, sobre-cabeça e vertical descendente. Avaliou-se a qualidade dos cordões por intermédio de ensaios não-destrutivos e análise macrográfica. Também analisaram os custos envolvidos para a determinação de qual arame apresenta maior produtividade para a tarefa descrita. Tendo como resultado o arame maciço uma sendo uma operação mais simples, já que o arame tubular exigiu maiores cuidados no momento da

soldagem. No que se refere a produtividade, foi possível empregar velocidades de soldagem maiores com arame tubular o que permitiu o preenchimento da junta em menor tempo.

Souza et al, em (2013) [95] desenvolveram uma avaliação em juntas soldadas pelo processo GTAW com caraterísticas utilizadas em bobinas de Spools, a serem empregadas na construção de plataformas off-shore. Após a soldagem, as juntas foram avaliadas por meio de microscopia ótica indireta utilizando réplicas metalográficas para caracterização da microestrutura do metal de solda.

\subsubsection{Pesquisas em Juntas de Chanfro Estreito}

Com a atual necessidade de aumentar a produtividade na união de componentes metálicos, muito se tem trabalhado no desenvolvimento de novas formas de soldagem, objetivando uma redução no tempo de fabricação. No caso de soldagem em peças de grande espessura, uma alternativa é o uso da técnica de "chanfro estreito" (narrow gap, em inglês), que pode ser aplicada com vários processos, como o arco submerso, GMAW e TIG. Dentre as vantagens está a de diminuir o volume de material a ser depositado e, consequentemente, o tempo gasto no processo. Deste modo, será apresentado as pesquisas relacionadas a chanfro estreito.

Corlett et al [96], em 1991 gerou um desenvolvimento de sensores apropriados e técnicas de sensoriamento para o controle do processo de soldagem TIG (GTAW) Narrow-Gap. Sistemas baseados na detecção de arco e sensoriamento por visão direta, foram desenvolvidos e testados com êxito em um sistema de soldagem experimental. O sensor de tensão-arco utilizado incluiu a concepção de uma técnica digital para cálculo do tamanho da queda de tensão como a tocha de soldagem, quando este se aproxima de uma parede lateral.

Lopez em (2006) [97] aplicou uma técnica de sensoriamento de arco de soldagem em chanfro estreito. Também desenvolveu diferentes sistemas de controle para melhorar a deposição de cordão de solda em chanfro estreito utilizando técnicas de oscilação. Porém, estas técnicas não são adequadas para todas as aplicações e em alguns casos, os parâmetros de oscilação (frequência e largura) são difíceis de optimizar e reduzir significativamente a velocidade de soldagem.

Em 2009, Badheka [34] desenvolveu uma técnica de soldagem em chanfro estreito que permitiu a união de chapas de até $300 \mathrm{~mm}$ de espessura utilizando uma junta de soldagem com 
chanfro reto ou, então, com chanfros em "V" com pequeno ângulo, menor do que $10^{\circ}$ de preparação (para compensar a deformação angular que ocorre pela contração da solda e que poderia fechar à junta), não possuindo uma abertura na parte mais estreita.

Egerland [98] investigou a eficiência do processo em um chanfro estreito usando CMT-P e GMAW-P. Mesmo que um número limitado de teste fossem realizados e erros experimentais não fossem estimados, existe uma indicação de eficiência do trabalho este processo é significativamente mais rápido, aproximadamente $10 \%$, para aplicações que utilizam a geometria do chanfro estreito quadrado (a eficiência do processo de $85 \%$ ).

Vieira (2012) [15] desenvolveu uma tocha adequada para a soldagem de chapas grossas (acima de $50 \mathrm{~mm}$ ) pelo processo GMAW com preparação da junta em U e pequena abertura $(10 \mathrm{~mm})$, assim como a especificação de um procedimento de soldagem que nessas condições dispense o préaquecimento. A tocha de soldagem, foi projetada para obter uma proteção gasosa eficaz. Foram realizados ensaios em chanfro em U com vários modos de transferência metálica: curto-circuito; spray pulsado e spray pulsado com dupla pulsação (pulsado térmico). Para logo verificar que ao realizar a soldagem em chanfro estreito as soldas tinham resistência mecânica e resistência ao impacto satisfatórias, mesmo quando executadas sem pré-aquecimento.

Sun et al [99], em 2013 efetuaram um estudo sobre o problema da fusão incompleta na parede lateral no chanfro estreito com soldagem (GTAW), por meio da distribuição da pressão de arco em cinco diferentes estilos de pontas de eletrodo de tungstênio: $30 U$ cone circular; $60 U$ cone circular; $60 U$ cone circular com cone truncado de $2 \mathrm{~mm}$ de diâmetro; terraço de $262 \mathrm{~mm}$ e terraço de 260 de 8 milímetros, com os mesmos parâmetros de soldagem. A pressão do arco foi verificada por ensaio na seção transversal da camada de soldagem em condição de campo magnético de controle na soldagem de chanfro estreito. O equipamento de medição que projetaram foi de forma independente em soldagem GTAW sob campos magnéticos.

Rencetemente em 2014, Asserin et al, [100] descreveram uma abordagem para determinar uma fonte de calor $3 D$ dedicado a uma nova configuração de processo de soldagem industrial (multi-passe de profundos chanfros estreitos em aços carbono com processo de soldagem GMAW, dois passes por camada), para avaliar o encolhimento do chanfro que ocorre durante a soldagem por simulação numérica. Os parâmetros desta fonte de calor $3 D$ são identificados por meio da resolução de um problema inverso de condução de calor por meio de um método dos mínimos quadrados. A otimização com a ferramenta multi-resposta é realizada com uma nova métrica proposta (distância Haus-Dorff) na função objetivo (soma dos quadradso), a fim de simular forma e temperaturas relevantes do cordão na zona sólida. 


\subsubsection{Pesquisas em Soldagem Orbital}

Na revisão da literatura se dispõe de muitas pesquisas na área de soldagem na posição plana, já que todo o processo se dá na mesma posição em sua grande maioria, sem variação angular de montagem. Alguns pesquisadores têm se interessado em conhecer os efeitos gerados na soldagem por processos realizados fora da posição plana, no caso da soldagem de tubos, inclui posições de solda plana, vertical e sobre cabeça, no qual a variação do ângulo de soldagem tem um efeito significativo na geometria do cordão de solda e nas suas propriedades. Neste sentido, na presente seção, serão apresentados os trabalhos desenvolvidos por pesquisadores no campo de soldagem orbital.

Ghor et al [101], em 2003 desenvolveram um método alternativo de transferência metálica a ser aplicado na soldagem de união e reparo de dutos, com vistas a consolidação do processo GMAW como resultados encontrando por intermédio de ensaios curto-circuito controlado, automatizando a operação de soldagem de dutos, através de um cabeçote MIG Orbital.

Broering [102] em 2005 apresentou um desenvolvimento de dois sistemas para automação da soldagem e corte térmico. Um deles é um sistema de deslocamento com dois graus de liberdade do tipo "tartaruga". O outro é um sistema destinado à mecanização da soldagem de tubos de parede fina sem a adição de material. Na linha da automação da soldagem, fez-se a concepção de um sistema orbital para a soldagem de tubos de parede fina. Encontrando soluções para tornar os desenvolvimentos de bancada em um produto robusto, confiável e compacto para ser utilizado em campo (sistema de soldagem TIG orbital e sistema de deslocamento com dois graus de liberdade). Deste modo o trabalho é finalizado com ensaios de soldagem preliminares, ainda sem uma integração geral das partes do sistema.

Em 2006, Pinto [103] avaliou os parâmetros de soldagem empregados na execução da soldagem circunferencial, combinando os processos de eletrodo revestido para a execução do passe de raiz e passe quente, usando arame tubular autoprotegido para a execução dos passes de enchimento e acabamento. Os resultados obtidos indicam que embora o material utilizado, tanto metal de solda como metal de base estejam atendendo aos requisitos básicos de tenacidade e resistência, em acordo com as normas, a qualificação do procedimento é dependente do desempenho dos soldadores. As propriedades mecânicas foram avaliadas mediante ensaios de dureza, tração, dobramento, ensaios nick-break e tenacidade mediante ensaios de impacto Charpy. A caracterização da junta soldada foi realizada, utilizando-se microscopia ótica.

Bracarense et al, [104] elaboraram uma metodologia para definir os parâmetros ótimos para a soldagem orbital robotizada de tubuluções, utilizando o processo FCAW com proteção gasosa. Aplicando duas etapas: na primeira etapa foram feitos testes em chapas e tubos com um soldador 
qualificado, tendo como resultado melhorias na qualidade da geometria dos cordões de solda depositados nas posições : vertical e sobrecabeça, logo na segunda etapa. Definido os parâmetros de soldagem, segundo as normas de soldagem foram transferidos para um robô antropomórfico revalidando a primeira etapa, tendo como resultado uma elevada taxa de deposição com o processo utilizado, oferendo excelente resultados de produtividade, qualidade e de custo.

Rocha [10] em 2010 fez um estudo sobre a soldabilidade do tubo API 5L X80 nacional, com $508 \mathrm{~mm}$ (20") de diâmetro e $19 \mathrm{~mm}$ (3/4") de espessura, comparando duas combinações de processos de soldagem circunferencial: MAG-TC (Soldagem MAG com transferência Controlada) + AT-PG (eletrodo tubular proteção gasosa) e MAG-TC + AT-AP (eletrodo tubular auto-protegido). As juntas soldadas foram caracterizadas utilizando-se: análise química; saturação magnética; metalografia óptica e eletrônica de varredura e ensaios mecânicos tais como: dureza Vickers; tração; dobramento; "nick-break" e ensaio de impacto a $0^{\circ} C$. Acompanhando como requisitos técnicos básicos para a qualificação de um procedimento de soldagem conforme a norma API 1104. Os resultados mostraram que segundo os critérios da norma API 1104, o processo MAG-TC em conjunto com o AT para enchimento e acabamento, apresentaram-se como uma alternativa viável para a substituição do processo ER na soldagem de tubos de aço API 5L X80, na outra combinação foi reprovado no ensaio "nick-break" devido à ocorrência de falta de fusão na raiz de um dos quadrantes.

Costa em 2011 [3] estabeleceu vantagens e limites operacionais dos processos GMAW com transferência por curto-circuito convencional e controlado (STT, RMD e CMT), em união de dutos de pequeno diâmetro e parede fina com passe único, nas progressões ascendente e descendente, levando em consideração os critérios de aceitabilidade e a geometria dos cordões. Variando os parâmetros de regulagem de cada processo, a velocidade de alimentação do arame, além das técnicas de soldagem, como o ângulo de ataque e oscilação da tocha, procurando manter a mesma quantidade de material depositado por comprimento de solda. Os resultados mostraram que a progressão ascendente possui maior capacidade de penetração, enquanto que a descendente é mais apropriada para maiores velocidades de soldagem.

Pesquisas feitas em 2012: como Magalhães [28] que desenvolveu um Simulador de Soldagem de dutos por retificação. Associada a facilidade de soldar chapas ao invés de tubos, utilizando processos com alta produtividade de forma automatizada. Dirigido a soldagem do passe de raiz com uso de transferência metálica por curto-circuito (convencional e derivativo). A análise dos cordões de solda obtidos através de inspeção visual e análise metalográfica (macrografia), com base nos critérios de aceitabilidade da norma API 1104 atestou a capacidade dos processos em realizar soldas de qualidade no processo de simulação da união de dutos. Com base nos resultados das análises foi possível definir faixas operacionais (envelopes de trabalho) para os processos estudados. 
Filho et al [105], Fizeram comparações dos processos convencional, CCC e STT para realização de passe de raiz nas posições vertical descendente e ascendente. Utilizando um sistema de aquisição de dados juntamente com filmagens em alta velocidade, possibilitando o aperfeiçoamento no processo de soldagem CCC, para que este fosse aplicado na soldagem de passe de raiz para a soldagem de dutos, com ganhos em confiabilidade e qualidade nas uniões.

Logo Ribeiro [5] desenvolveu uma bancada para soldagem de tubos rotacionais e estáticos, com a adaptação de tochas para fazer injeções: radial e tangencial de arame, aplicando o processo de soldagem TIG conferindo ganhos em produtividade, orientado a obter penetração total e repetitividade na soldagem do passe de raiz. Realizando estudos com a face da raiz em 2 e $4[\mathrm{~mm}]$ sem abertura para verificar o comportamento da penetração da solda o autor fez um experimento fatorial com três réplicas na posição $1 G$, avaliando a interação com a geometria do cordão de raiz, posição de alimentação de arame pela frente e por trás do arco mantendo o ângulo de alimentação radial para os tubos. A metodologia foi avaliada por meio de ensaios de viabilidade em soldas de raiz com corrente pulsada e alimentação radial de arame na posição $5 G$ e $6 G$ e com corrente constante na posição $6 G$ com introdução tangencial de arame, e constatou-se que ambos os métodos foram considerados como viáveis a aplicação da solda de raiz.

Em 2013, Cayo [6] desenvolveu um modelo da transferência de massa, junto com a modelagem da oscilação da poça de fusão e a modelagem da regulação dos parâmetros de soldagem em função da posição da tocha de soldagem orbital, para o processo GMAW no modo de transferência por curto-circuito (GMAW-S) visando obter soldas uniformes diante da mudança da posição de soldagem. Por meio de experimentos o autor conseguiu verificar a uniformidade relativa das soldas a partir de regulação dos parâmetros de soldagem em função a posição, utilizando os modelos propostos. Concluindo que o escoamento da poça é inevitável, reduzindo os efeitos através do controle do valor final das oscilações por meio da regulação dos parâmetros de soldagem em função da posição.

Aures [42] desenvolveu um equipamento denominado simulador de Soldagem de dutos por retificação $(S S D R)$, o qual realiza uma soldagem com características semelhantes a de uma soldagem circunferencial, realizando a soldagem em chapas planas, utilizando o metal de base chapa plana ao invés de tubo. Este equipamento foi utilizado para avaliar processos derivativos aplicados ao passe de raiz obtido pela simulação física da soldagem circunferencial, realizouse a simulação da soldagem externa de um tubo de 8" de diâmetro nominal, na progressão descendente de $180^{\circ}$ (meia cana), em junta de chanfro estreito. Em uma segunda abordagem é apresentada uma metodologia usada para determinar a altura da face de raiz ou nariz, a qual permite realizar o passe de raiz pelo lado externo do tubo, em soldagem de topo sem abertura de raiz e sem utilizar cobre-junta. A partir do tamanho correto encontrado para a face de raiz, foram realizados dois processos de simulação, em juntas com e sem cobre-junta, e posteriormente 
foram realizadas soldagens de tubos de forma convencional com sistema circunferencial. Ensaios de macrografia foram realizados, verificando-se um bom passe de raiz e sem defeitos internos, validando a metodologia apresentada, assim como o funcionamento do SSDR.

Meneses [106] desenvolveu e implementou um modelo híbrido do processo GMAW na soldagem orbital, construído sob a aplicação de um tratamento físico e matemático específico para a modelagem dos períodos de formação, crescimento e transferência da gota, que compõem o modo de transferência por curto circuito, a fim de compreender os fenômenos físicos e dinâmicos envolvidos no processo. As respostas obtidas pelo modelo foram complementadas com o estudo da estabilidade da transferência de metal em experimentos reais, para ter uma visão global que combine o conhecimento obtido pela análise de experiências reais conduzidas, com os resultados gerados por ferramentas computacionais. Os resultados apresentados foram satisfatórios e se refletem na melhoria da aparência e qualidade do cordão de solda.

Meller et al [107], em 2014 elaboraram uma metodologia afim de procurar os parâmetros que se precisan para soldagem orbital de preenchimento de uma junta em "V" em tubos por meio do processo GMAW e no passe de raiz com CCC (curto circuito controlado), com os parâmetros obtidos para cada situação, foi possível produzir cordões de solda de boa qualidade. Deste modo os cordões de solda foram submetidos a ensaios radiográficos e nenhum tipo de falha comprometedora foi evidenciado.

Em síntese, com base no embasamento teórico e a revisão bibliográfica especializada, fezse uma motivação ao tema de pesquisa proposto, a fim de implementar uma metodologia de soldagem orbital de união de tubos por meio de chanfro estreito em " $U$ " sem abertura de raiz, aplicando o processo de soldagem GMAW por curto circuito convencional e derivativo, baseado em tecnologia CMT desenvolvida pela Fronius em passe de raiz. Assim, é aplicado uma metodologia experimental de superfície de respota por meio de Desenho Central Composto (CCD) e o método de otimização de multiplas respotas Desirability, para obter um conjunto ótimo de determinado parâmetros estabelecidos, para obter penetração completa por meio da metodologia de nariz inclinada de chanfro estreito, em três posições críticas de soldagem (plana, vertical e sobrecabeça) executado em chapas planas de aço 1020. Uma vez aplicada a etapa anterior logo é implementando esta metodologia em soldagem Orbital como validação com o processo de soldagem convencional em posição $5 \mathrm{G}$ estabelecido em tubo ASTM A 106, que não apresente defeitos internos e disponibilize a utilização de dois tipos de elétrodos. 


\section{METODOLOGIA EXPERIMENTAL}

Neste capítulo será apresentada a metodologia de pesquisa propriamente dita, e seus conceitos. Considerou-se a sequência mostrada na Fig. 1.1, desde a $1^{a}$ até a $3^{a}$ etapa, critérios para a seleção dos procedimentos adotados para a coleta e tratamento de dados e as limitações dos métodos utilizados.

\subsection{METODOLOGIA}

\subsection{1 $1^{a}$ Etapa: desenvolvimento de estrutura para diferentes posições e ensaios preliminares}

Em tubulações o cordão de solda é depositado em diferentes posições ao longo do perímetro do tubo, incluindo as posições de solda plana, vertical e sobre cabeça, consideradas as posições mais críticas para este trabalho, nas quais a variação do ângulo de soldagem tem um efeito significativo na geometria do cordão de solda e nas suas propriedades. Por meio dessa informação, para realizar testes de soldagem nas três posições já mencionadas, foi necessário construir um dispositivo ou estrutura que facilitasse a fixação e o posicionamento das placas de teste, com o propósito principal, e adicionar algumas funções para torná-lo mais versátil.

Nos laboratórios de pesquisa, quando se trabalha com soldagem de tubulação, testes preliminares são realizados em chapas planas nas 3 posições de soldagem, que geram mudanças abruptas na forma da deposição de material, com o intuito de obter um conjunto de parâmetros adequados (parametrização), os quais desempenham uma soldagem com boas características visuais e mecânicas, isto é, os parâmetros de soldagem devem ser os mesmos. Posteriormente, estes parâmetros serão utilizados na soldagem orbital. A Fig. 3.1, representa uma soldagem circunferencial, em $180^{\circ}$ mostrando ainda o posicionamento da tocha nas posições críticas da soldagem circunferencial e o seu equivalente na soldagem em chapas planas. 


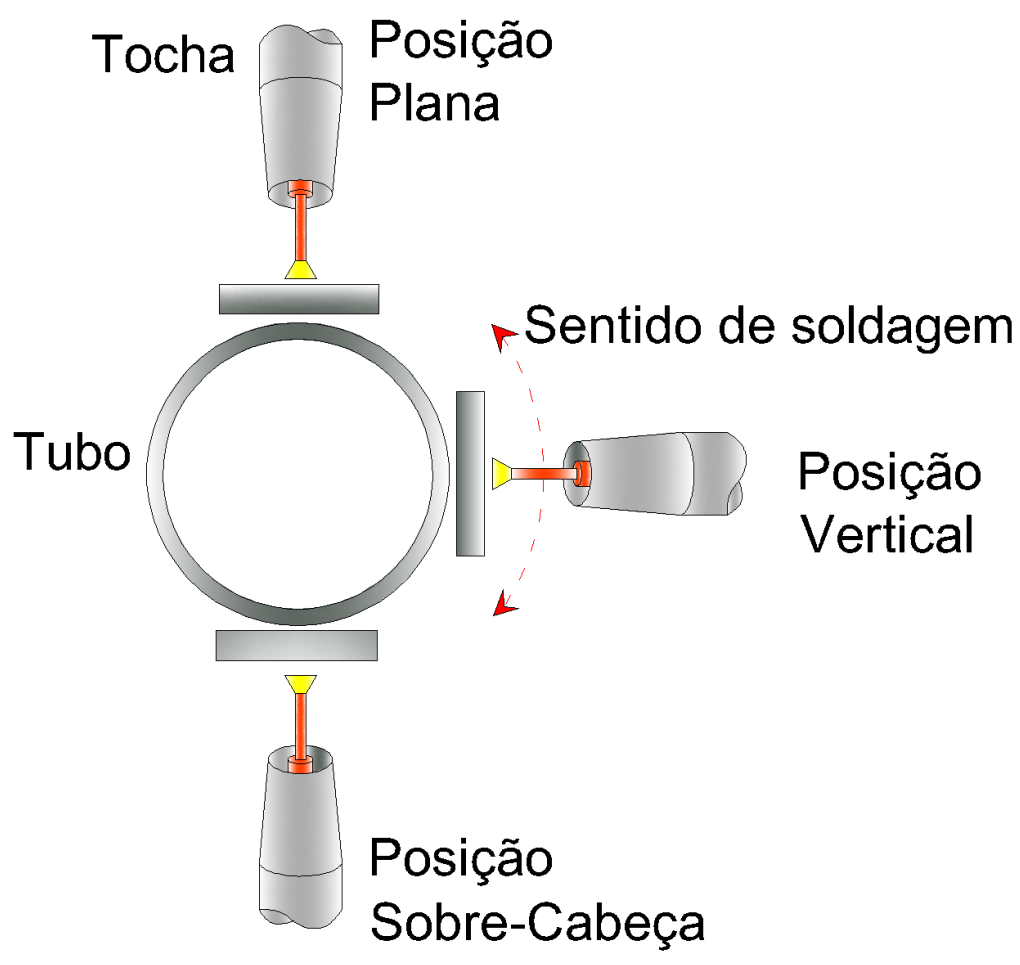

Figura 3.1. Posicionamento da tocha nas posições críticas da soldagem circunferencial.

No momento da realização dos testes preliminares tem-se uma grande dificuldade, já que isto implica um posicionamento das chapas como mecanismos para fixação destas chapas em bancadas de soldagem, por meio de parafusos, grampos, sargentos e algumas vezes são soldadas em outra estrutura. Da perspectiva académica estas fixações provocam variações indesejadas nos experimentos como: distorções; falta de repetibilidade; perda de tempo no montagem e desmontagem das chapas.

O suporte é uma estrutura desenvolvida por Aures [42], para o presente trabalho foi adaptada segundo as necessidades estabelecidas (facilidade de segurar as chapas, posicionamento, e baixo custo na construção), ela é de aço e é dividida em duas partes: a primeira parte é denominada de "mesa", onde as chapas de teste são fixadas e a segunda parte é uma estrutura "base" que consta principalmente de duas hastes cilíndricas paralelas, onde a mesa se desliza, e de uma cantoneira central na qual ajuda na fixação e na mudança de posição da mesa. Estes detalhes são mostrados na Fig. 3.2.

Com o propósito deste trabalho em fazer um suporte de maior versatilidade, além da tradicional fixação das placas de teste, foram projetadas algumas funções, apresentadas a seguir: a mesa tem duas chapas base com 4 parafusos de aço dispostos ao longo de cada uma delas, e duas cantoneiras as quais pressionam as placas de teste sobre as chapas base, fixando-as. A pressão das cantoneiras sobre as chapas é resultado do aperto dos parafusos posicionados nas chapas 


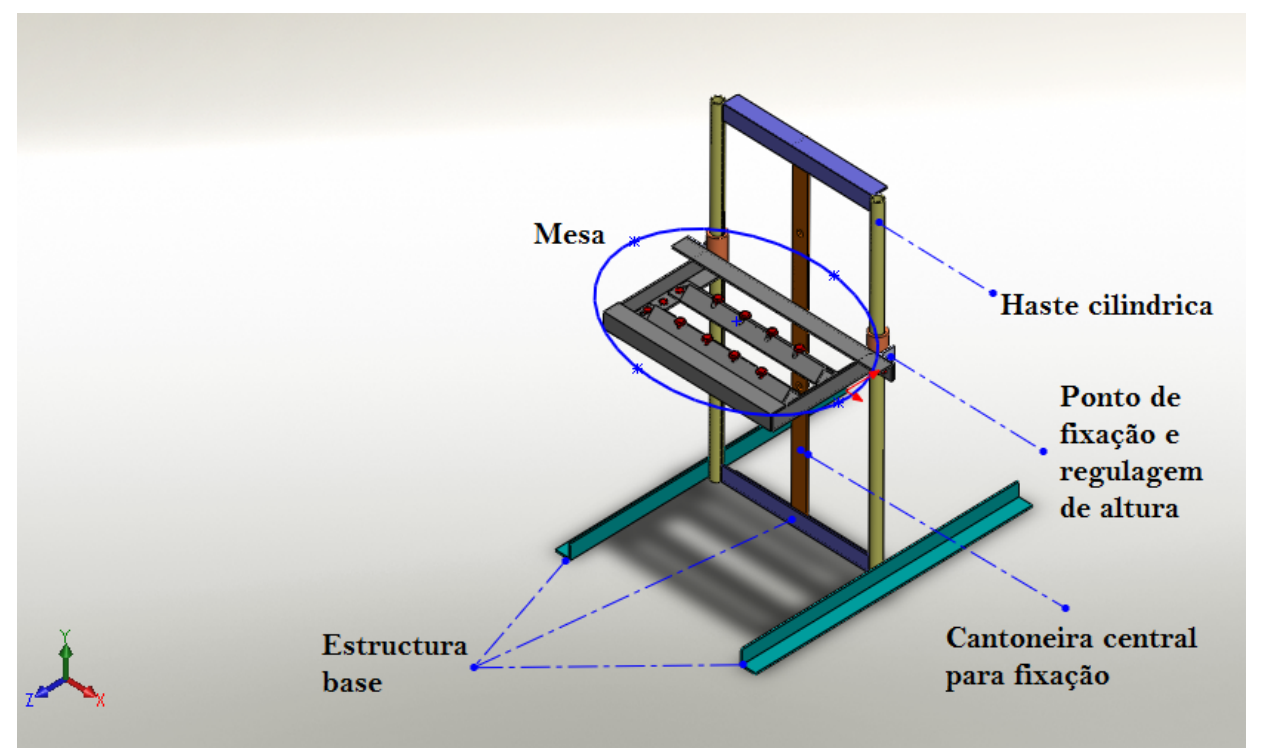

Figura 3.2. Suporte para fixação e posicionamento de placas de teste.

base, também foram feitas ranhuras transversais nas cantoneiras, onde os parafusos são posicionados, permitindo que estas cantoneiras possam girar sobre o seu eixo longitudinal e possam fixar placas de teste de maior espessura, esta funcionalidade das partes da mesa é mostrada na Fig. 3.3.

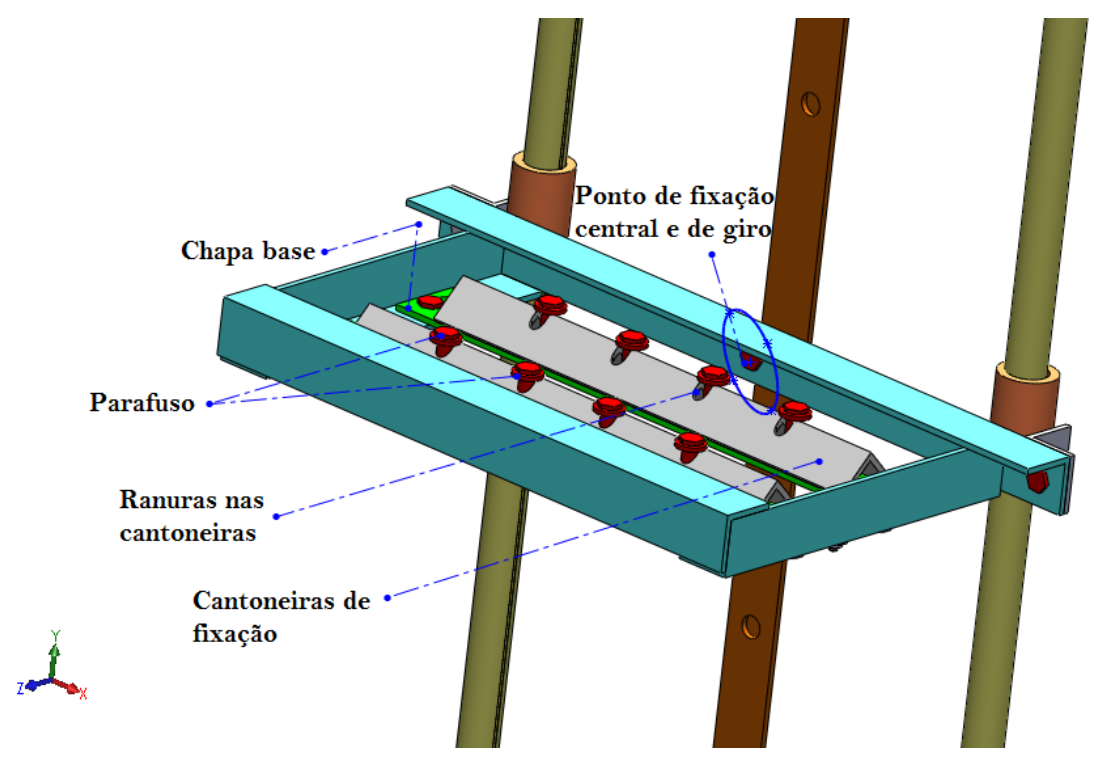

Figura 3.3. Detalhe da mesa junto com os seus componentes.

A mesa construida Fig. 3.3 tem uma versatilidade em relação as posições críticas de soldagem já preestabelecidas, é fixada na base por meio de três parafusos, um em cada extremidade (haste cilíndrica) e um no ponto central (cantoneira central), fazendo com que a mesa e as placas de teste possam ser trocadas de posicionamento para realizar a soldagem plana, vertical e sobrecabeça, como explicado a seguir: 
- Na posição plana: a mesa é parafusada pelos extremos em duas pequenas seções de tubos (por meio de pequenos traços de cantoneira soldados a mesa e as hastes cilíndricas) e no ponto central(cantoneira central). Desparafusando o ponto central e reduzindo a pressão dos anéis de tubos se permitirá o deslizamento destes anéis sobre as hastes cilíndricas modificando com isto, a altura de fixação da mesa e das placas de teste.

- Para a posição vertical: foram realizados três furos igualmente espaçados na cantoneira central e na mesa. Para se efetuar a mudança para a posição vertical é necessário retirar os parafusos das extremidades, reduzir o aperto do parafuso central na cantoneira e girar a mesa, a $90^{\circ}$ sobre o eixo do parafuso neste ponto central, parafusando novamente a mesa,desta vez na cantoneira central da estrutura base.

- Para a posição sobrecabeça: a fixação é similar à fixação da posição plana, mas deve-se girar a mesa em $180^{\circ}$, na posição mais alta permitida.

A Fig. 3.4 mostra o suporte com a mesa e as placas de testes finalmente posicionadas nas três posições, para a qual foi projetada: plana, vertical e sobrecabeça.
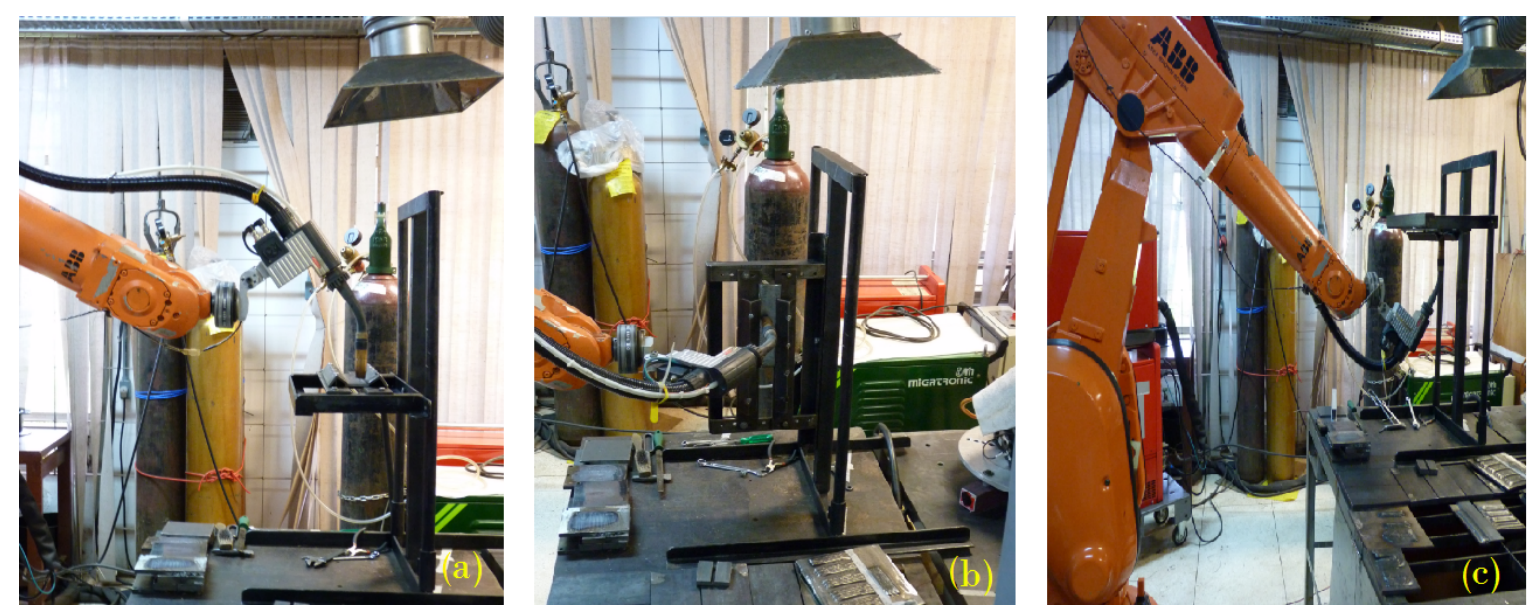

Figura 3.4. Suporte com a mesa e chapas de teste posicionadas para a soldagem (a) plana, (b) vertical e (c) sobrecabeça.

Cabe salientar que o suporte foi desenhado para ser usado sobre uma bancada, logo o posicionamento da mesa foi projetada, para a posição sobrecabeça de tal forma que o robô IRB 2000 da ABB Robotics, do Laboratório GRACO(grupo de automação e controle) da FT (Faculdade de Tecnologia), possa posicionar a tocha sob da mesa permitindo a soldagem nesta posição, como mostrado na Fig. 3.4(c).

Uma vez construida a estrutura para as diferentes posições de soldagem caminha-se para encontrar os parâmetros apropriados, que possa realizar um cordão de solda direcionado a passe de raiz com o processo GMAW-CMT, com boas características físicas e visuais, sem apresentar defeitos internos. 
Desta forma, este trabalho foi iniciado com a ideia de usar chapas planas (aço ABNT 1020, 200x50x6 mm mostrada na Fig 3.5). A espessura de $6 \mathrm{~mm}$ foi escolhida com o intuito de evitar o desperdiço de material, toda vez que com esta espessura se atinge a altura do cordão de passe de raiz recomendado na literatura. Em seguida, com ajuda dos parâmetros baseados nas referências bibliográficas foram realizados os testes preliminares procurando apresentar a mesma geometria do cordão nas três posições de solda, (os testes são aplicados com a Fonte TransPuls Synergic 5000 CMT), para logo fazer um análise do perfil de onda da transferência com respeito à utilizada por Magalhães [28] com a Fig. 2.3.

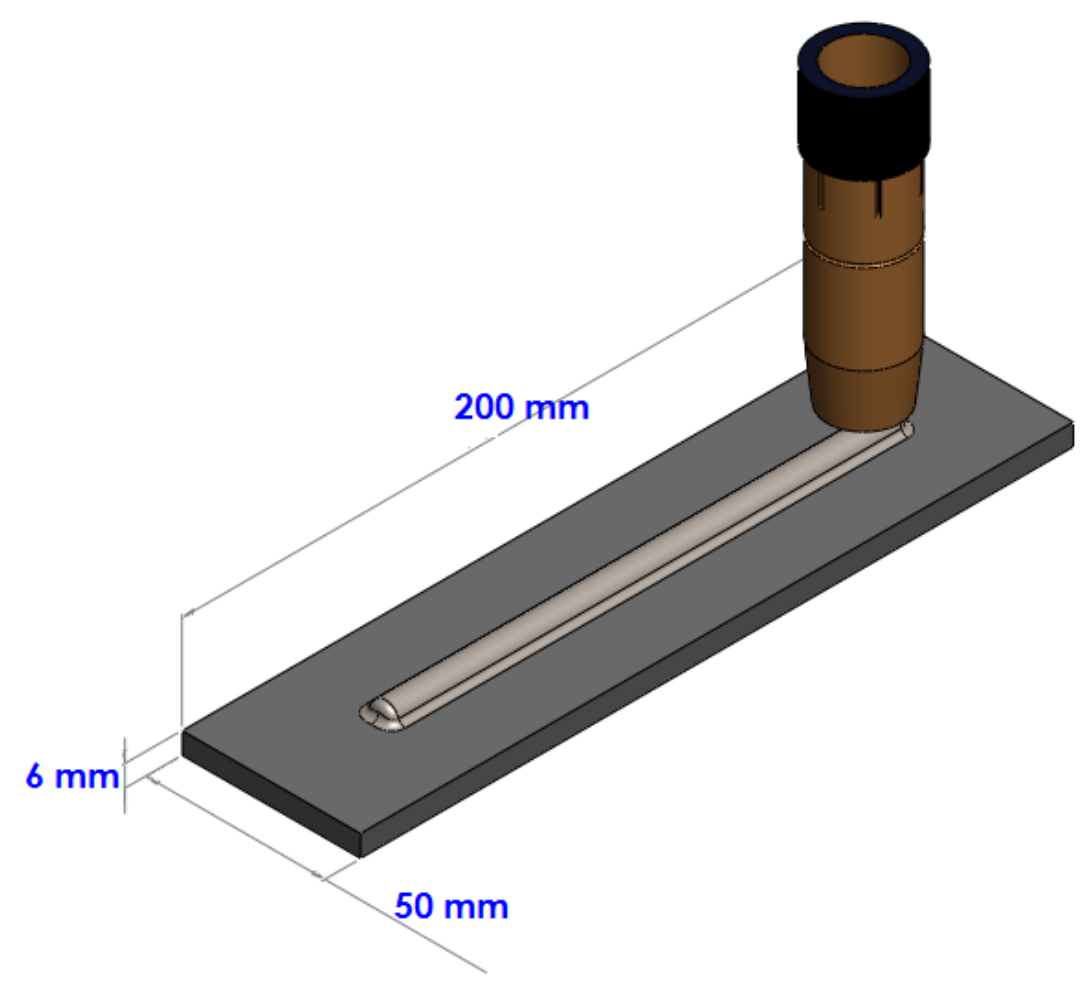

Figura 3.5. Esquema da chapa para testes preliminares.

Os testes preliminares foram realizados com deposição de cordão sobre chapas, utilizando diversas configurações de parâmetros e velocidade de soldagem até obter-se resultados condizentes para um bom passe de raiz. Nesta fase obtiveram-se cordões com algumas descontinuidades de soldagem, baixo respingo e por conseguinte um cordão com boas características visuais, até finalmente chegar à configuração que permitiu a repetibilidade de resultados. Como ponto de partida, foram selecionadas várias velocidades de alimentação de arame, e comprimento de arco. Em seguida foram definidos os parâmetros iniciais para seguir à etapa 2. 


\subsection{2 $2^{a}$ Etapa: determinação da espessura de nariz para obter penetração completa em três posições críticas de soldagem}

O objetivo desta etapa é obter os parâmetros apropriados sob condições determinadas, com os quais se possa realizar um cordão de solda de passe de raiz com boas características físicas e visuais, com bom aspecto visual na face do cordão sem desvios de cordão, mordeduras, e que o reforço da raiz apresente penetração total e homogênea ao longo do cordão, além de não apresentar defeitos internos como porosidades, inclusões e nem falta de fusão.

\subsubsection{Metodologia de Chanfro com nariz Decrescente}

Na realização do passe de raiz um fator determinante é o formato da junta. Como foi estudado anteriormente ele determina o procedimento de soldagem que vai ser utilizado. Porém, são encontrados diferentes problemas desde o momento em que as partes a serem soldadas são encostadas uma na outra, dando o formato final da junta que vai ser preenchida, a saber:

- Problemas de alinhamento.

- Dificuldades para manter a abertura de raiz constante ao longo das chapas ou do perímetro do tubo.

- Falta de fusão ou, do modo contrário, perfuração.

- Contaminação pelo cobre da cobre-junta, a qual é colocada ao redor do diâmetro interno do tubo, com o intuito de evitar vazamento do metal líquido da poça de fusão.

- Tempo gasto para a colocação da acopladeira dentro do tubo, além do alto custo que resulta o aluguel deste dispositivo.

Por estas razões que decidiu-se trabalhar o chanfro estreito sem cobre-junta, um passe de raiz com boas características é conseguido por tentativa e erro, como foi apresentado anteriormente na literatura. Uma metodologia que mostra como determinar uma configuração de junta foi apresentada por Aures [42], onde especifica como atingir uma boa penetração no passe de raiz.

Com isso, neste trabalho é adaptado um procedimento que permite a construção de uma configuração de junta, especificamente, da espessura de nariz, com a qual se consegue realizar o passe de raiz sem utilizar cobre-junta, em uma soldagem de topo e sem abertura de raiz. Isso garante realizar uma soldagem circunferencial pelo lado externo do tubo sem precisar de espaçador e nem de cobre-junta. Considerou-se trabalhar com a mesma configuração de junta exposta na Fig. 2.9b, para mostrar que a execução desta metodologia evita a construção do 
pequeno chanfro na parte inferior desta junta, diminundo com isto o tempo gasto na usinagem desta parte da junta, assim como desalinhamento devido à menor complexidade do formato da junta. Nestes testes não se utilizou pré-aquecimento.

Um fator fundamental para a construção desta junta é a espessura da face de raiz. Tendo em consideração uma determinada condição de soldagem (parâmetros de soldagem), a face de raiz precisará ter a espessura suficiente para permitir uma fusão total que possa manter aderida o estado líquido da poça de fusão ao metal de base sem ter vazamentos ou furar devido à pressão, e que permita um reforço aceitável na raiz do cordão após a solidificação, além de não apresentar defeitos internos. Por meio disso, pensou-se que a soldagem deverá ser realizada em uma junta que tenha a espessura de nariz variável, isto é, um formato decrescente que começe com um valor máximo, neste caso $4 \mathrm{~mm}$, e termine em um valor mínimo, $0 \mathrm{~mm}$. Assim, essa metodologia foi denominada de "Método do chanfro de nariz decrescente".

Barras chatas de aço ABNT 1020 de 120x35x12,9 $\mathrm{mm}$ foram utilizadas. O comprimento das chapas foi determinado de $120 \mathrm{~mm}$ com o intuito de poder realizar a fixação entre elas somente por pontos de solda nos extremos. Isso evita interferências ou defeitos que um ponto de solda pode originar quando colocado no meio do comprimento das chapas no momento da passagem do arco elétrico sobre a face do "nariz decrescente", podendo modificar ou disfarçar resultados na determinação do ponto de penetração total após a deposição do cordão. Os 12,9 $\mathrm{mm}$ de espessura na chapa foi escolhido para poder analisar o comportamento da face de raiz do cordão dentro do chanfro, e também por que a espessura do tubo a ser utilizado na etapa 3 , onde estabelece uma proximidade na geometria da configuração das juntas nas duas etapas.

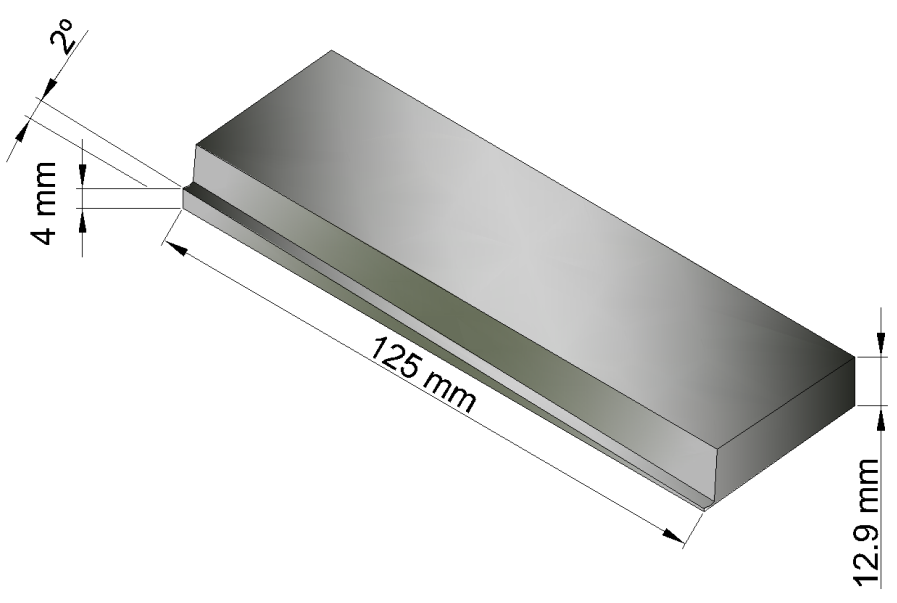

Figura 3.6. Medidas da chapa com a metodologia de nariz decrescente.

Com estes valores o ângulo de inclinação do nariz variável (de 0 a $4 \mathrm{~mm}$ ) é de 1,91º, não obstante para ter esta medida requer uma boa calibração dos equipamentos de chanfrar, tendo em conta esta dificuldade optou-se por ter um ângulo de $2^{\circ}$. A configuração final desta junta é mostrada na Fig. 3.6. 
A espessura variável do nariz foi medida e apresentada os seguintes valores: 1, 2, 3 e $4 \mathrm{~mm}$, como mostrado na Fig. 3.7, e foi riscado estes pontos pela parte posterior das placas de teste com a finalidade de ter um melhor controle da espessura do nariz em cada ponto ao longo da junta, mostrado na Fig. 3.8.

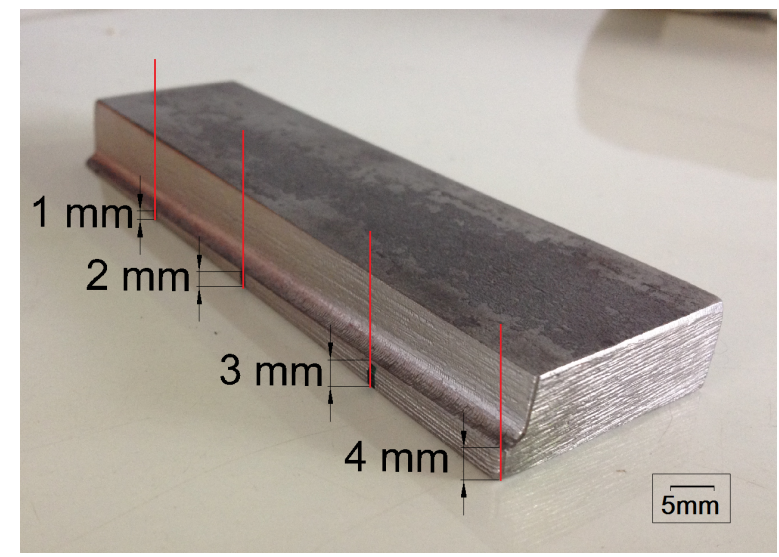

Figura 3.7. Nariz variável ao longo do comprimento do metal de base.

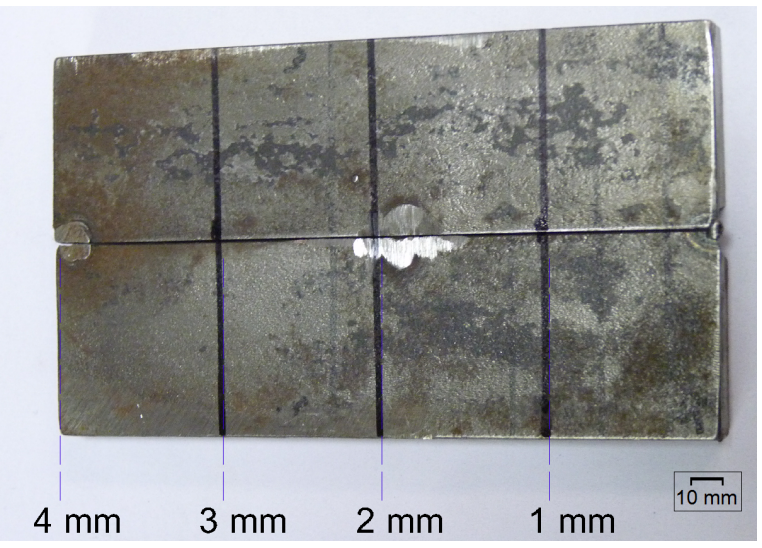

Figura 3.8. Linhas riscadas na parte inferior da junta, mostrando a espessura de nariz nesses pontos.

As placas de testes já maquinadas e prontas com o chanfro estreito em U com nariz decrescente, são mostradas na Fig. 3.9.
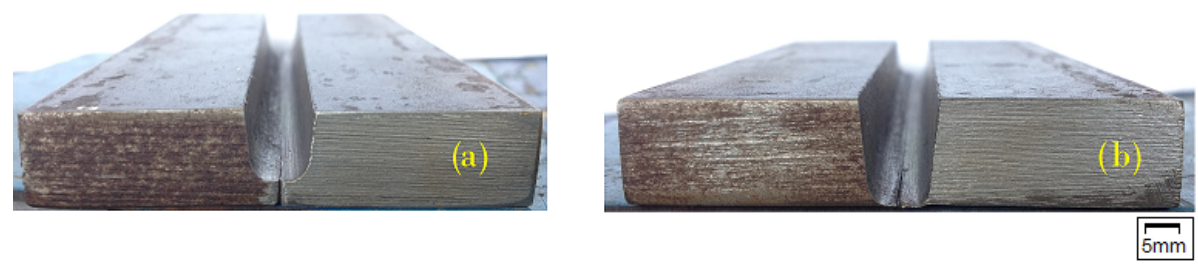

Figura 3.9. Disposição final da junta com a altura do nariz variável, com valores de: (a) $4 \mathrm{~mm}$ e (b) $0 \mathrm{~mm}$. 
Nesta junta a metodologia da soldagem começa no ponto mais alto $(4 \mathrm{~mm})$ e termina no ponto mais baixo $(0 \mathrm{~mm})$. Deste modo, durante o trânsito da soldagem e em algum determinado ponto a fusão total do nariz será conseguida, o que será visível pelo lado oposto da junta. Desta forma, neste ponto de fusão total, por uma simples relação de triângulos, determina-se a espessura do nariz para essa condição de soldagem, que permite realizar o passe de raiz sem utilizar cobrejunta.

Uma montagem esquemática de como a metodologia funciona, em soldagem na posição plana, é apresentada na Fig. 3.10, e detalhada a seguir:

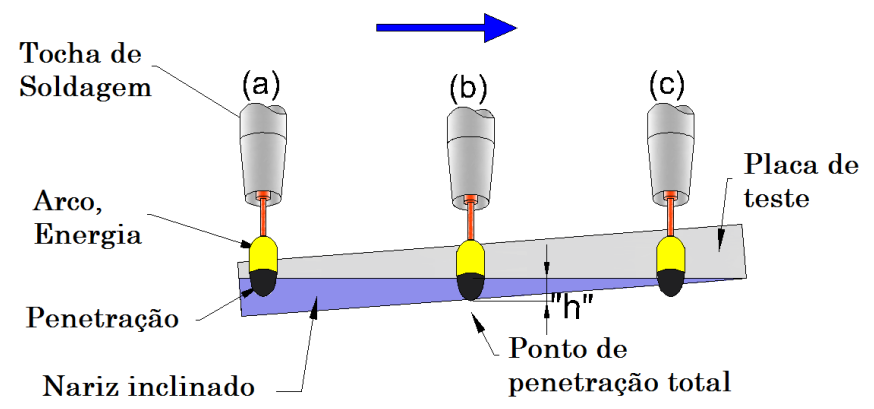

Figura 3.10. (a) Ponto de início da solda apresentando uma penetração conseguida com uma determinada energia, (b) ponto de penetração total onde o tamanho "h" é a espessura de nariz encontrada para essas condições (c) posição final da tocha.

As chapas de teste prontas, como foram mostradas na Fig. 3.9, são fixadas e posicionadas na "estrutura" de tal forma que a nariz decrescente da junta fique com a face (parte superior) em uma posição perpendicular ao deslocamento da tocha (Fig. 3.10), isto com o propósito de evitar induzir maior escorregamento ou queda do metal líquido da poça, originado por uma inclinação maior, o que provoca defeitos e dificulta a penetração.

Com a tocha posicionada no ponto (a), considerando uma soldagem plana (Fig. 3.10), o arco é estabelecido com determinados parâmetros de soldagem $(I$ e $U)$, estes fornecem uma energia que origina uma determinada penetração no ponto onde o arco atua (Fig. 3.10a). Dessa maneira o processo de soldagem é realizado movimentando-se a tocha desde a posição (a) até a posição (c). Durante este processo, em algum ponto do percurso, a fusão total do nariz é conseguida (Fig. 3.10b).

Assim que foi conseguida a penetração total da raiz efetuou-se a medição da distância deste ponto a uma das linhas riscadas na chapa de teste (Fig. 3.8), linhas entre as quais se encontra o ponto de penetração total. Logo, conhecendo-se o valor da distância entre as linhas, o valor da distância de uma linha até o ponto de penetração total e conhecendo-se o valor do ângulo do nariz decrescente, a espessura ou altura de nariz "h", com a qual se consegue a penetração total, pode ser determinada por um simples cálculo de relação de triângulos. 
A realização deste procedimento nas 3 posições críticas da soldagem circunferencial aconteceu em 3 diferentes pontos de penetração total que se reflete em 3 espesuras de nariz diferentes, por causa do efeito que a posição de soldagem, fazendo originar na poça de fusão e nas forças que ajudam no destacamento da gota, explicitamente pela força de gravidade. Teve-se cuidado em manter a face do "nariz decrescente" na posição horizontal ou vertical, sempre perpendicular ao deslocamento da tocha, isto com o intuito de evitar induzir escorregamento do metal líquido durante a soldagem. A Fig. 3.11, esquematiza estes posicionamentos.

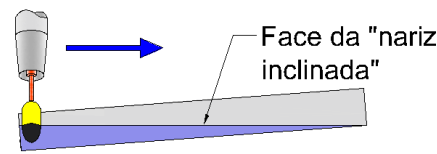

(a) Soldagem Plana

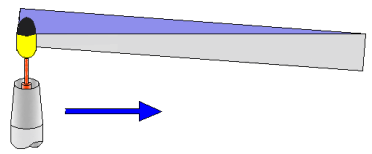

(c) Soldagem

Sobrecabeça

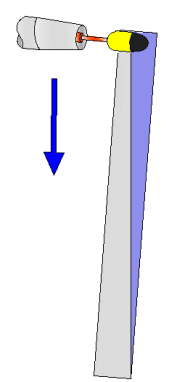

(b) Soldagem Vertical descendente

Figura 3.11. Disposição das chapas de teste com a superfície do "nariz decrescente" perpendicular ao deslocamento da tocha nas 3 posições (a)plana, (b) vertical, (c)sobrecabeça.

\subsubsection{Construção das juntas de chanfro estreito em "U"}

Foi determinado neste trabalho usar o "chanfro estreito" como configuração de junta a ser utilizada para a união das chapas planas e dos tubos, como foi mostrado na Fig. 2.9d. Este tipo de chanfro requer menos metal de enchimento, que contempla menos energia, menos tempo usado no preenchimento da junta, diminindo com isso as distorções e o tempo de soldagem. Por tanto, a junta é compreendida por duas partes que têm um formato de chanfro em "J", com $5^{\circ}$ de inclinação na parte superior, com um arco de raio de $2,5 \mathrm{~mm}$ para evitar defeitos em quinas quadradas, e que encostadas uma na outra, oferecem um formato em "U".

Tendo em conta as limitações, falta de chanfradeira para a construção da junta em chanfro estreito, foi utilizada uma plaina e uma ferramenta de aço. Assim, foi necessário preparar a ferramenta de aço rápido num formato similar ao do chanfro e, para se ter um melhor controle das medidas na fabricação da junta, foi utilizado um "calibre ou gabarito" com uma medida de raio de 2,5mm. Na Fig. 3.12, é mostrado o formato final da ferramenta utilizada e como foi utilizada. 
Foram usadas chapas de aço ABNT 1020 com dimensões de 120x35x12,9 mm (comprimento $\mathrm{x}$ largura $\mathrm{x}$ espessura). a largura de $35 \mathrm{~mm}$ foi escolhido com o intuito de ajudar a dissipar o calor fornecido pelo processo de soldagem, ajudando a ter um maior aproveitamento das peças por seu baixo custo comercial, nas outras duas dimensões já formam justificadas na metodologia do "nariz decrescente". Para conseguir usinar os $5^{\circ}$ de inclinação do chanfro na junta da chapa, foi preciso girar a morsa que fixa a chapa no momento da usinagem. Estes detalhes de construção são mostrados na Fig. 3.13.
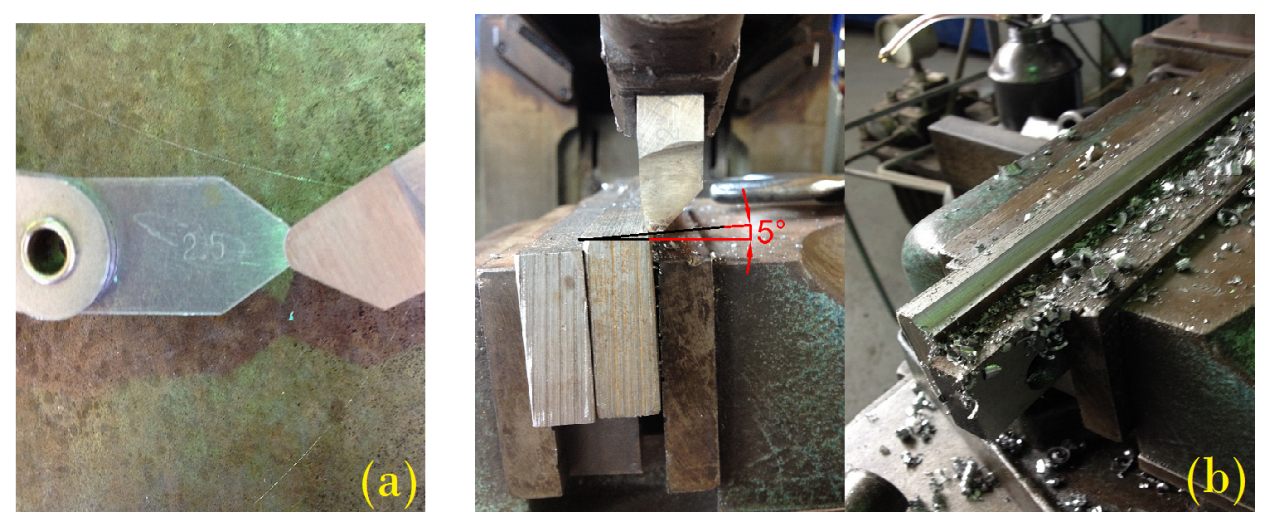

Figura 3.12. (a)Formato da ferramenta de aço rápido utilizada na fabricação da junta, (b)Construção da junta.

Depois de terminada a usinagem das chapas, com o formato de junta desejado, estas são fixadas uma na outra por 3 pontos de solda, um em cada extremo e um no meio, pela parte inferior. Realiza-se assim a soldagem dessas juntas em todas as posições, em junta de topo, sem usar cobre-junta, obtendo um cordão sem defeitos internos, para as condições de soldagem impostas neste trabalho. A nova configuração da junta é determinada, considerando a espessura de nariz encontrada, "h", aplicando o planejamento proposto para organização dos parâmetros e assim conseguir ter o formato final para passar na 3ra etapa.
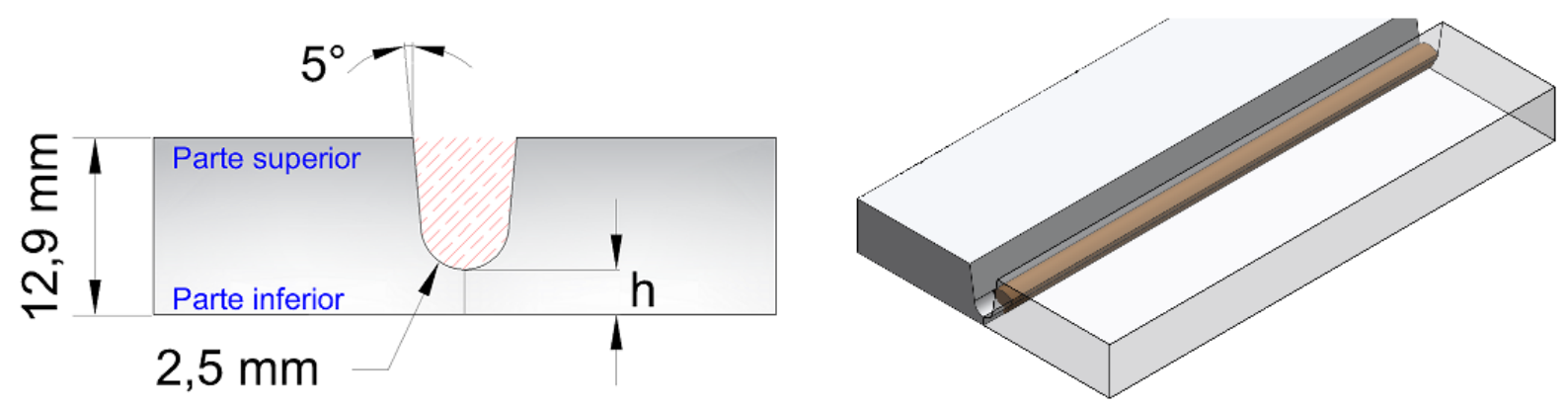

Figura 3.13. Configuração final da junta onde "h" é o valor de nariz encontrado, para validar a metodologia de chanfro con nariz decrescente nas 3 posições e logo na soldagem orbital. 


\subsubsection{Planejamento experimental.}

A seleção de um desenho adequado em relação ao experimento a ser realizado é fundamental para analisar o comportamento da penetração aplicado no processo de soldagem GMAW-CMT. O objetivo foi encontrar um conjunto de parâmetros para obter uma penetração completa sem defeitos internos nas juntas de chanfro estreito e sem mata-junta, baseado no Planejamento Composto Central ( $C C D$ ) da metodologia de superfície de resposta para se organizar os ensaios e obter os modelos matemáticos das posições críticas de soldagem, logo sendo otimizadas pelo método Desirability, sendo assim, uma configuração de junta é obtida em barras chatas para logo ser validada em soldagem de tubos.

Para a elaboração dos planejamentos foi utilizado um programa comercial (Minitab ${ }^{\circledR}$ ), este programa é projetado para executar funções estatísticas básicas e avançadas, fornece o total de corridas segundo os fatores que vão ser utilizados. A seguir são definidos os fatores e os seus respectivos níveis a serem usados no planejamento experimental.

Os níveis codificados e as variáveis de entrada com suas faixas de trabalho aplicado no Planejamento Composto Central estão expostos na Tabela. 3.1.

Tabela 3.1. Níveis y faixas dos Parâmetros de soldagem selecionados para

Desenho Composto Central.

\begin{tabular}{|c|c|c|c|c|c|c|}
\hline \multirow{2}{*}{ Parâmetros de soldagem } & \multirow{2}{*}{ Símbolo } & \multicolumn{5}{|c|}{ Níveis } \\
\cline { 3 - 7 } & & $\mathbf{- 1 , 6 8 3}$ & $\mathbf{- 1}$ & $\mathbf{0}$ & $\mathbf{1}$ & $\mathbf{1 , 6 8 2}$ \\
\hline Velocidade de alimentação do Arame (m/min) & $V_{a}$ & 3,82 & 4,1 & 4,5 & 4,9 & 5,2 \\
\hline Velocidade de Soldagem $(\mathrm{mm} / \mathrm{s})$ & $V_{s}$ & 4,25 & 4,5 & 5 & 5,5 & 5,75 \\
\hline Comprimento de Arco & $l_{a}$ & -30 & -15 & 0 & 15 & 30 \\
\hline
\end{tabular}

\subsection{3 $\quad 3^{a}$ Etapa: soldagem circunferencial em Tubo}

O objetivo desta etapa foi avaliar os resultados obtidos na $1^{a}$ e $2^{a}$ etapa, aplicando a soldagem em tubos.

A união de tubos de grande diâmetro e espessura, pelo processo de soldagem, é realizada pelo passe de raiz, passe de enchimento e passe de acabamento. Tendo em conta que neste trabalho foi usada a soldagem mecanizada de passe de raiz, depositado pela parte externa do tubo em uma soldagem descendente em meia volta, em campo, é realizado da seguinte forma: biselamento dos tubos; acoplamento antes de serem soldados; soldagem pelo dispositivo mecânico-eletrônico na progressão descendente em meia volta. 


\subsubsection{Biselamento dos tubos}

Nesta fase o processo começa pelo biselamento dos tubos, podendo ser realizado na fabricação ou em campo, por meio de biseladoras o ou chanfradeiras, neste caso já definido o formato da junta em chapas planas se procede a aplicar nos tubos como é mostrado na Fig. 3.14. Houveram algumas dificuldade no momento de preparar a junta, já que por defeito de fabricação ele não apresenta um formato circunferencial concêntrico com diâmetro interno do tubo. No caso deste trabalho, o tubo foi fixado na castanha do torno, posicionado de tal forma que o desalinhamento do formato oval, quando o tubo gire, fosse reduzido. Depois usinou-se a parte interna, de um lado do tubo, até uma medida onde conseguiu um desgaste uniforme no diâmetro interno do tubo. A seguir o tubo foi faceado.

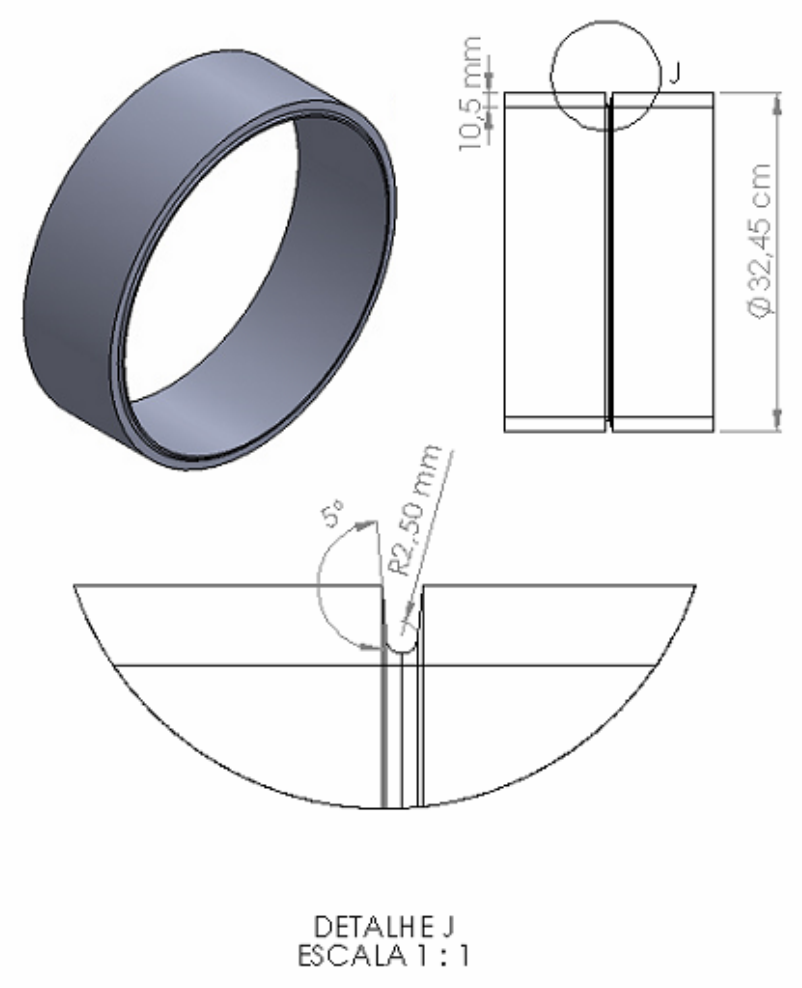

Figura 3.14. Dimensões do duto utilizado para soldagem.

Posteriormente, o procedimento foi repetido pelo outro lado do tubo, utilizando o mesmo sistema de fixação para a construção do formato da junta da Fig. 3.14, por meio disso conseguiuse uma aproximação de um diâmetro interno homogêneo diminuindo o desalinhamento da parte interna do tubo, facilitando ter um maior controle na construção da espessura do nariz, desta parte interna do tubo. A espessura do tubo ficou com um valor aproximado de 10,5 mm, toda vez que o diâmetro externo do tubo continua tendo o formato oval inicial. A Fig. 3.15, mostra o tubo fixado e pronto para construção da junta. 


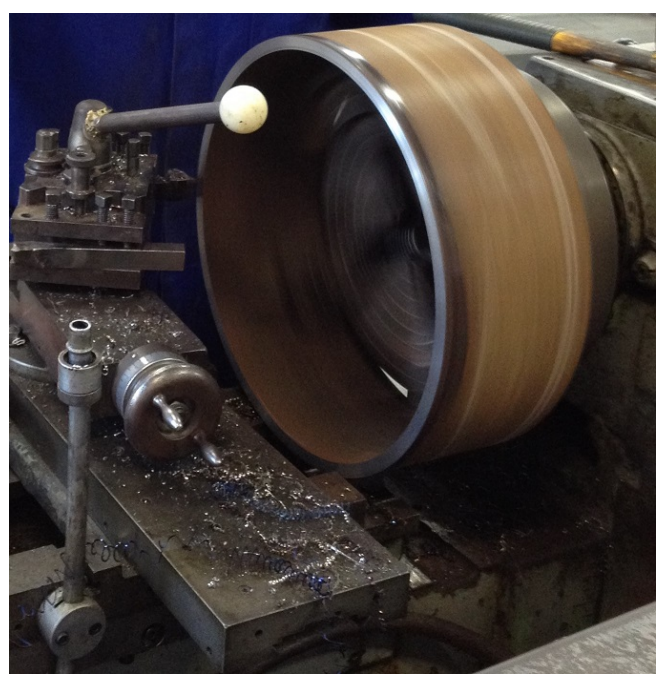

Figura 3.15. Seção ou anel do tubo durante o processo de usinagem de uniformização do diâmetro interno

Em seguida, a junta foi preparada de acordo com a Fig. 3.14. Para a construção da junta, usou- se novamente a configuração da ferramenta de metal duro diferente à usada nas chapas por que a dureza do tubo é maior (Fig. 3.12), mas desta vez deslocada angularmente para atingir os $5^{\circ}$ de inclinação. A Fig. 3.16 mostra a posição da ferramenta durante a construção do formato da junta e o tamanho do nariz desejado no tubo.
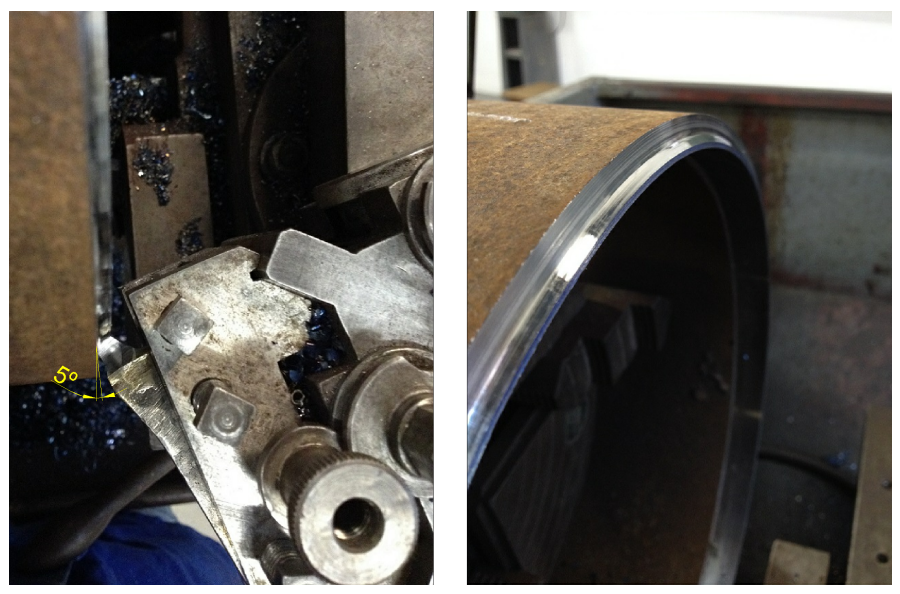

Figura 3.16. Posição da ferramenta no ponto final da construção do formato da junta no tubo.

Os tubos são acoplados ou encostados um no outro, sendo esta etapa de fundamental importância, pois define a junta a ser soldada, com isto, foram fixados por meio de travas previamente maquinadas com uma abertura entre abas na região central, de forma a não haver interferência na geometria e nem na solidificação do cordão, também com a função para que a linha de escosto entre os tubos fique livre com o intuito de não interferir na penetração nem na formação de raiz do cordão. A Fig. 4.8 mostra os tubos já prontos para a soldagem circunferencial, e os detalhes da união entre eles. 


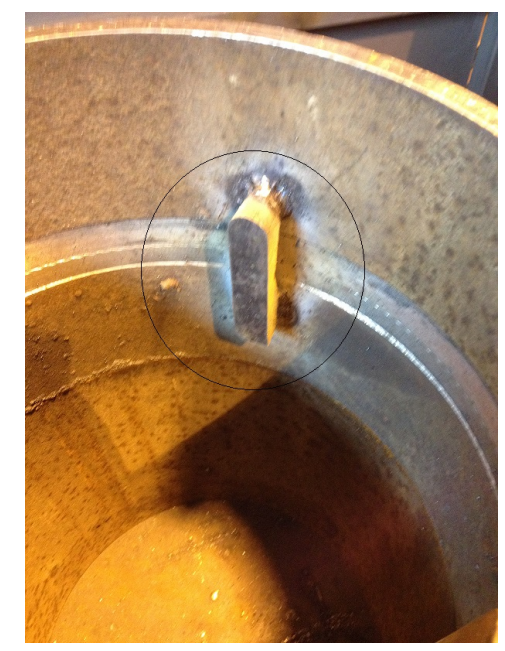

Figura 3.17. Configuração final de tubos internamente prontos para soldagem com os pontos de fixação.

Depois destas etapas, o tubo fica pronto para a soldagem com o formato da junta desejado, como mostrado na Fig. 3.18.

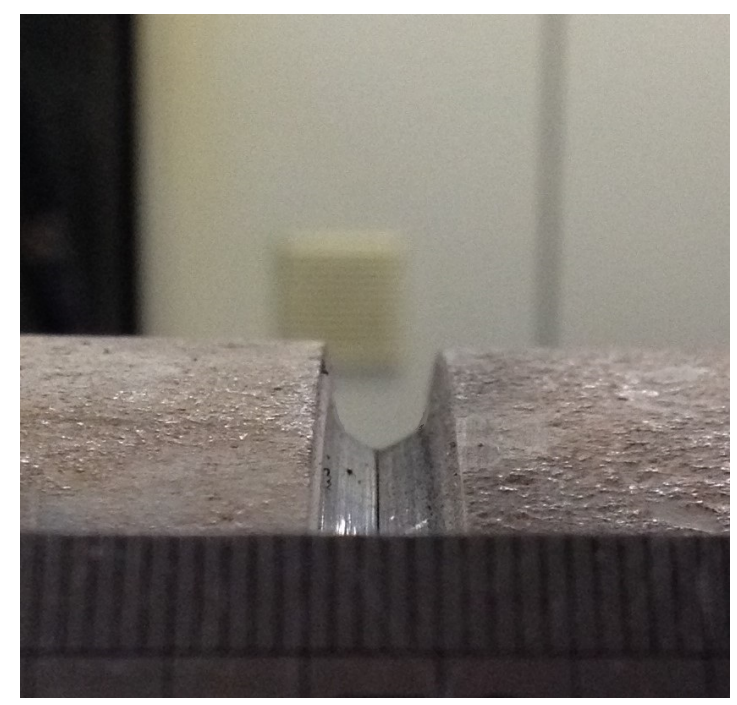

Figura 3.18. Formato final da junta nos tubos.

\subsubsection{Montagem e disposição do equipamento de soldagem}

A seguir será mostrado um dispositivo mecânico-eletrônico chamado de Manipulador Robótico, no qual se desloca sobre um trilho ou cinta rígida, fixado ao redor do diâmetro externo do tubo, levando consigo a tocha de soldagem e realizando a deposição do cordão de solda no comprimento programado.

Deste modo os tubos foram fixados em um dispositivo projetado para este fim. Este dispositivo desenvolvido no LRSS (Laboratório de Robótica, Soldagem e Simulação) da Universidade 
Federal de Minas Gerais UFMG, consta de um tubo transversal que contém dois espaçadores reuláveis ao diâmetro interno dos tubos a soldar, sobre o qual está fixado as cintas metálicas onde servem como referência para acoplar o robô ou cabeçote de soldagem, por meio de corrente metálicas. Isto facilita a soldagem específica para tubos de vários diâmetros, podendo ser trocados mais rapidamente. A Fig 3.19. mostra o sistema de fixação dos tubos.
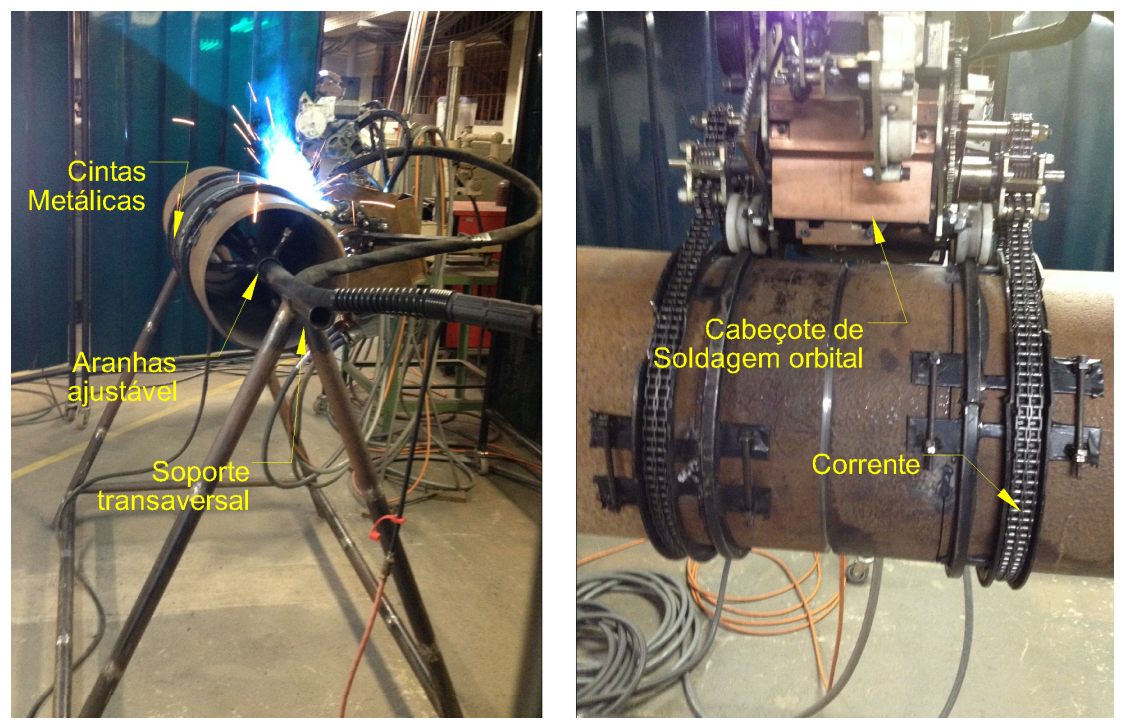

Figura 3.19. Sistema de fixação de tubos para soldagem orbital.

\subsubsection{Execução da soldagem Orbital}

Um aspecto importante a ser destacado na soldagem de tubos refere-se à progressão de soldagem. A soldagem de tubulações normalmente é feita com os tubos posicionados na horizontal (5G ou PF), que permanece parado enquanto a solda é feita sobre a junta posicionada na vertical. No caso da soldagem GMAW, a solda é feita em duas partes de $180^{\circ}$ (meia cana), com um cordão em uma metade do tubo seguida de um cordão do lado contrário para finalização da solda. No caso da norma AWS D10.12, para a soldagem de tubulações de aço carbono, com paredes com espessura até $12,9 \mathrm{~mm}$, recomenda-se utilizar processo GMAW para a realização do cordão de passe de raiz na progressão descendente.

Com todos os parâmetros e equipamentos prontos, a soldagem orbital foi realizada em posição $5 \mathrm{G}$ meia volta descendente em $180^{\circ}$ por um lado, deixando esfriar o tubo para depois movimentar o cabeçote orbital para o lado oposto, completando a soldagem circunferencial. Nesta situação, são realizados dois cordões de solda considerando o segundo cordão como uma réplica, para questão de análise, toda vez que é realizado com o mesmo procedimento e parâmetros para cada processo de soldagem.

Após a realização da soldagem foram retirados os corpos de prova dos tubos em um corte 
transversal do cordão, para análise de macrografia, com comprimento aproximado de $50 \mathrm{~mm}$ (comprimento aproximado de $10^{\circ}$ ). Isso foi considerado pois dentro desse comprimento a posição da tocha pode-se ainda considerar nas posições planas, vertical e sobrecabeça. Para as posições plana e sobrecabeça, considerou-se uma defasagem de $5^{\circ}$ após o começo e antes do fim da solda. A Fig. 3.20 mostra o posicionamento para extração dos corpos de prova com ênfase na faixa vermelhas.

A macrografia foi realizada após obtenção dos corpos de prova representativo de cada posição no tubo. As amostras foram preparadas com lixas de 220, 320, 420, 600 e 1200 e polidas posteriormente. Foi utilizado o ataque químico de Nital 3\% por 15 segundos. Após o ataque químico, foi realizada a medição das características geométricas do cordão através do sistema de aquisição de imagem e software analysis da empresa Olimpus.

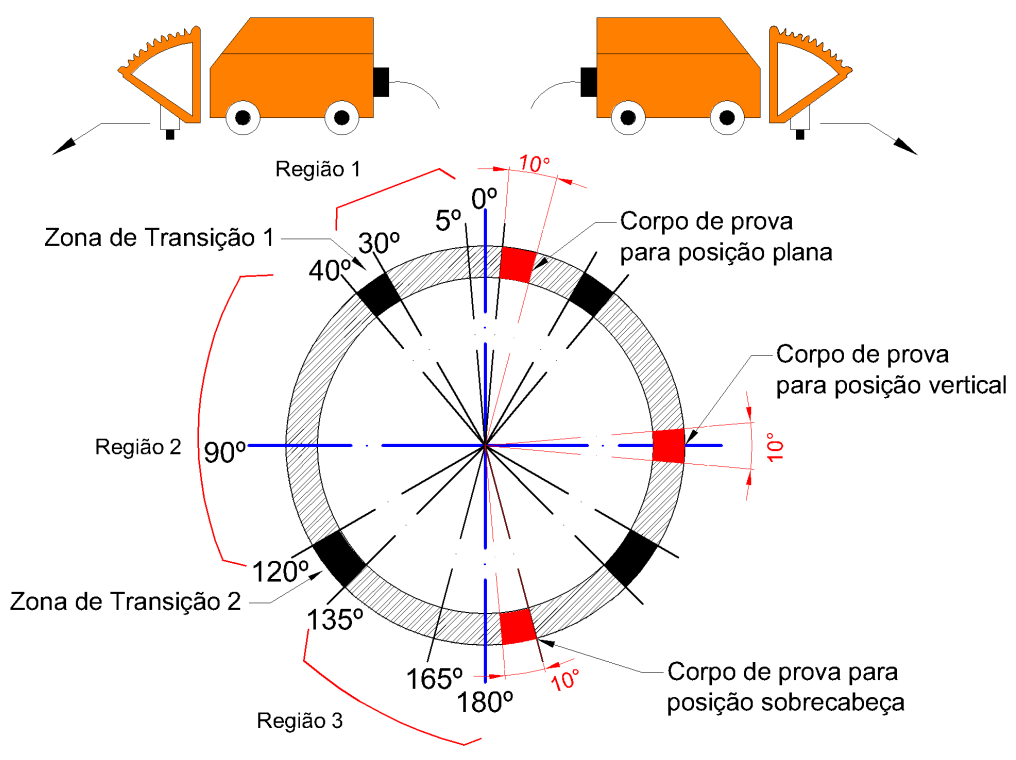

Figura 3.20. Desenho do corte transversal do tubo mostrando os pontos para extração dos corpos de prova para análise de macrografia.

\subsection{MATERIAIS}

Os materiais de base usados neste trabalho foram chapas planas da $1^{a}$ a $2^{a}$ etapa, em diferentes comprimentos, e tubos na $3^{a}$ etapa, como detalhados a seguir e segundo as etapas apresentadas na Fig. 1.1.

- $1^{a}$ Etapa: chapas de aço ABNT 1020 com 50x6x200 mm. Chapas com espessura de 6,0 mm foram utilizadas com o intuito de poupar material, toda vez que essa espessura é suficiente para comportar uma altura de cordões de passe de raiz como encontrado na literatura, a largura de $50 \mathrm{~mm}$ ajuda a ter vários cordoes na mesma chapa (Fig. 3.5). 
- $2^{a}$ Etapa: chapas de aço ABNT 1020 com 30x12,9x125 mm. Chapas de $125 \mathrm{~mm}$ de comprimento foram utilizadas com o intuito de fixar as chapas por pontos de solda nos extremos e na metade do comprimento destas, isto para determinar a profundidade de penetração quando o cordão seja depositado (Fig.3.6).

- $3^{a}$ Etapa: os tubos usados foram da série ASTM A106 com 12" de diâmetro externo e 9,7 mm de espessura de parede, com um comprimento de $400 \mathrm{~mm}$, considerando os dois anéis de tubos unidos (Fig. 3.14).

A Tabela 3.2 apresenta a composição química dos materiais bases utilizados nas três etapa da metodologia.

Tabela 3.2. Composição química (\% em peso) do metal base.

\begin{tabular}{|c|c|c|c|c|c|c|c|c|}
\hline COMPOSIÇÃO & $\% C$ & $\% M n$ & $\% S$ & $\% P$ & $\% S i$ & $\% C r$ & $\% N i$ & $\% M o$ \\
\hline $\begin{array}{c}\text { Aço (ABNT 1020) } \\
\text { Material de base }\end{array}$ & $0,18-0,23$ & $0,30-0,60$ & 0,050 & 0,04 & 0,04 & 0 & 0 & 0 \\
\hline $\begin{array}{c}\text { Aço ASTM A-106 } \\
\text { Material base (Tubo) [108] }\end{array}$ & 0,30 & $0,29-1,06$ & 0,035 & 0,035 & 0,10 & 0,40 & 0,40 & 0,15 \\
\hline
\end{tabular}

Para a realização dos testes foi utilizado no presente estudo, o arame ASME AWS SFA- 5.18 ER70S-6 com diâmetro de 1,2 mm para a primeira e segunda etapa, logo para terceira etapa foi utilizada de 1,2 e 0,9 mm para fazer uma comparação na energia que precisa para soldar o tubo em passe de raiz; este tipo de eletrodo sólido com composição química e propriedades mecânicas conforme apresentado na Tabela 3.3, a seguir (fornecidas pelo fabricante), este é revestido com uma película fina de cobre que dificulta a oxidação e facilita a transferência elétrica no material.

Tabela 3.3. Composição química e propriedades mecânicas do eletrodo

\begin{tabular}{|c|c|c|c|c|c|c|c|c|}
\hline \multicolumn{7}{|c|}{ Composição química AWS 70S-6 } \\
\hline$\% C$ & $\% M n$ & $\% S i$ & $\% P$ & $\% S$ & $\% N i$ & $\% C r$ & $\% M o$ & $\% C u$ \\
\hline 0,08 & 1,50 & 0,90 & 0,025 & 0,035 & 0,15 & 0,15 & 0,15 & 0,15 \\
\hline \multicolumn{7}{|c|}{ Propriedades Mecânicas } \\
\hline Gas de proteção & $\begin{array}{c}\text { Resistência á tração } \\
\text { KSI (Mpa) }\end{array}$ & $\begin{array}{c}\text { Limite Elástico } \\
\text { KSI (Mpa) }\end{array}$ & $\begin{array}{c}\text { Resistencia de } \\
\text { impacto Minimo } \\
\text { em Joules a }{ }^{\circ} \mathrm{C}\end{array}$ \\
\hline$C^{2} \mathrm{O}_{2}$ o misturas & $78(480)$ & $58(400)$ & $27-34{ }^{\circ} \mathrm{C}$ \\
\hline
\end{tabular}

O gás de proteção utilizado foi uma mistura gasosa Stargold Plus, mistura comercial especializada para soldagem $(G M A W) \mathrm{Ar}+25 \% \mathrm{CO}_{2}$, sendo adotada uma vazão de $15 \mathrm{l} / \mathrm{min}$. Segundo o 
fabricante, as principais vantagens deste gás é uma alta penetração, baixa incidência de respingos e excelente extabilidade do arco.

\subsection{EQUIPAMENTOS}

\subsubsection{Fonte de soldagem}

A fonte de soldagem utilizada na primeira e segunda etapa foi a TRANS PLUS SYNERGIC 5000 CMT com alimentador de arame VR 7000, digital e multiprocesso (SMAW, GTAW e GMAW). Para o processo GMAW-CMT, é regulado o comprimento do arco, sendo que a regulagem da velocidade de alimentação do arame é realizada na tocha. A soldagem foi feita com o robô IRB 2000 da ABB Robotics e a programação para um ou vários cordões com o Interface ROB 5000, a manipulação da fonte é feita por a unidade de controle remoto RCU 5000i e a programação para o robô é realizada com o Software Sport S3 (Fig. 3.21).
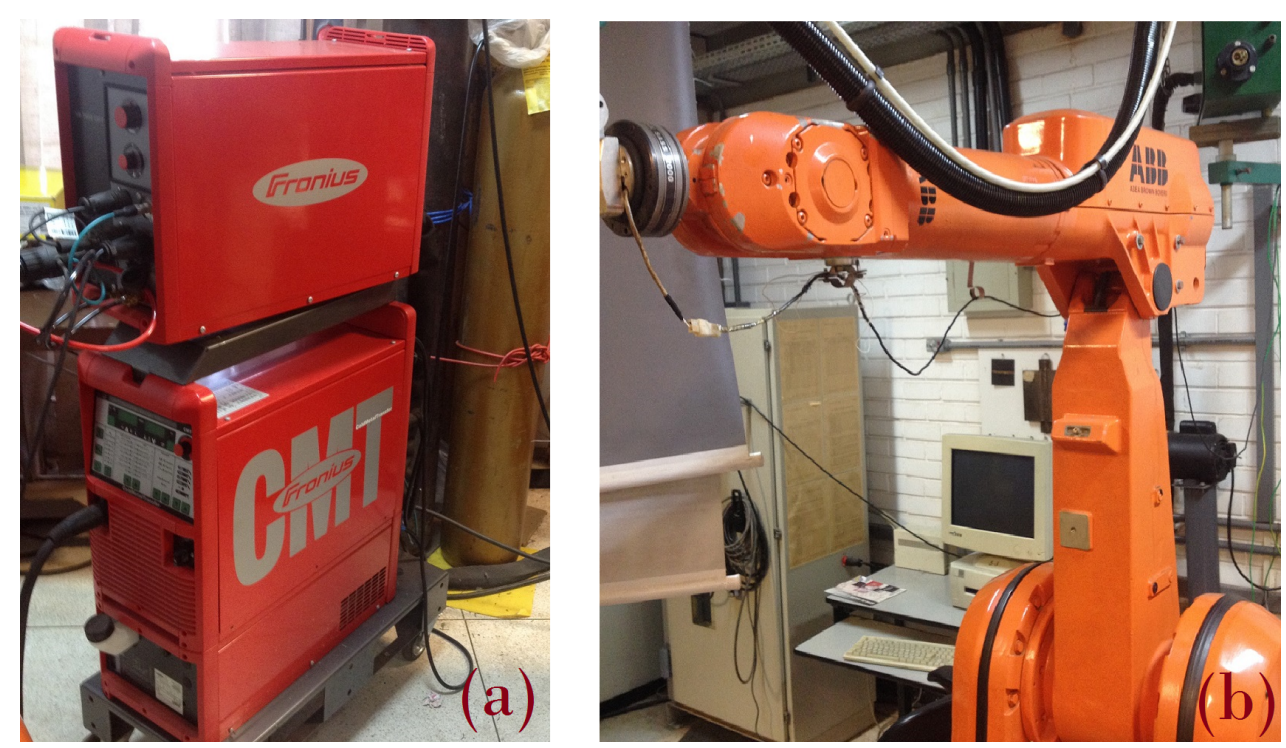

Figura 3.21. (a)Fonte Fronius, (b)Robô de Soldagem ABB Robotics.

A fonte de soldagem na terceira etapa foi uma SOLMIG 400-CV Eletronic, ela conta com um alimentador convencional de arame TR80-NAVY desenvolvida pela WHITE MARTINS, conta com conjunto de potência semi-industrial com ótima eficiência energética, arco estável, conjunto retificador, filtro de indutância possibilitam uma soldagem de baixíssimo índice de respingo e facilidade de abertura de arco para soldagem. Nesta fonte se controla a corrente de soldagem, já que a tensão se mantém constante (Fig. 3.22). 

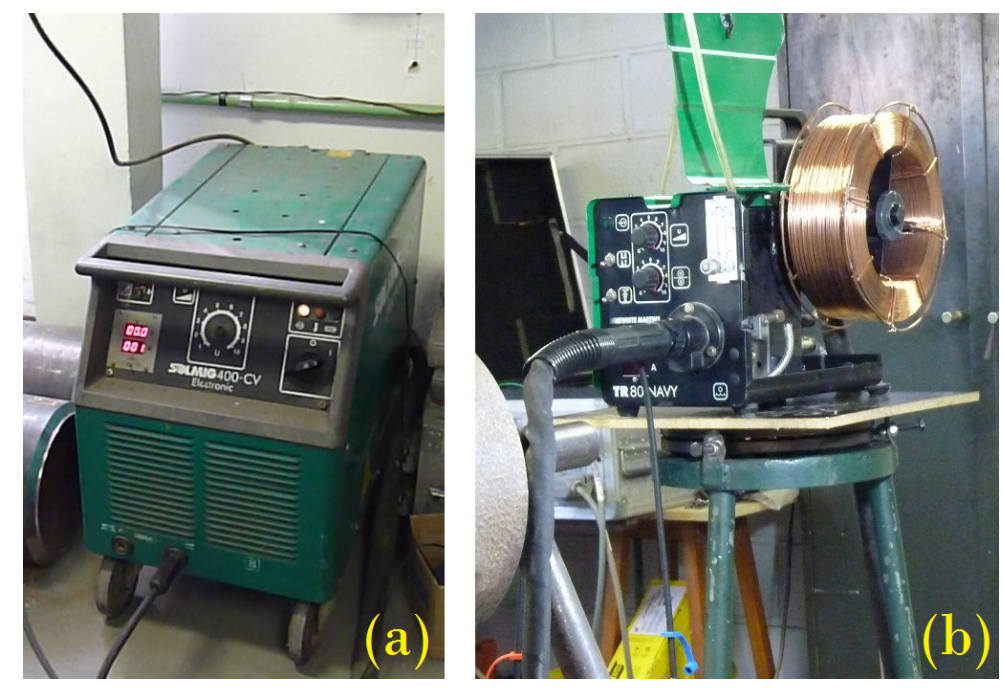

Figura 3.22. (a)Fonte de soldagem, (b)alimentador de arame.

\subsubsection{Sistema de translação da tocha}

Para movimentação da tocha, durante a primeira e segunda etapa deste trabalho, foi utilizado um braço mecânico da IRB 2000 da ABB Robotics, com 6 graus de liberdade e capacidade máxima na flange de $8 \mathrm{~kg}$, mostrado na Fig. 3.21(b).

Para a terceira etapa deste trabalho, foi utilizado um sistema orbital com 4 graus de liberdade, fabricado pela LRRS - Univ. Federal de Minas Gerais tendo a parceria entre o laboratório e uma empresa privada. Este equipamento permite a soldagem circunferencial, em tubos, como mostrado na Fig. 3.19.

\subsubsection{Tochas}

Na primeira e segunda etapa é utilizada uma tocha Robacta Drive CMT robotizada é particularmente adequada para o processo MIG Brazing, livre de respingos em chapas finas de metal galvanizado, e com aplicação geral em junção de aço e alumínio entre outros, o mesmo equipado com um servo motor CA sem engrenagem e altamente dinâmico: o arame de soldagem se movimenta para frente e para trás até $130 \mathrm{~cm} /$ segundo, oferecendo uma alimentação exata do arame e pressão de contato constante. Enquanto outro motor se encarrega da alimentação constante do arame. Entre estes motores está posicionado um "pulmão" ou buffer, que absorve o movimento do arame perante um conduite flexível posicionado dentro dele, mostrados na Fig. 2.4(a). A tocha CMT é mostrada na Fig. 3.23. Para a terceira etapa é utilizada uma tocha para curtocircuito convencional, produzida pela ROTECH (Rotech - Tecnologia Robótica). Esta é uma tocha refrigerada à água com corrente máxima de 380 A para mistura de gases. Na Fig. 3.19, se mostra a tocha montada na flange do cabeçote de soldagem. 


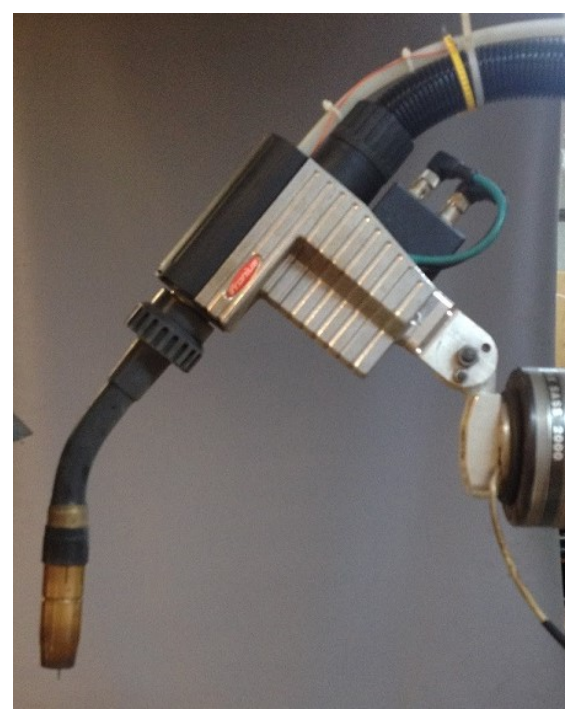

Figura 3.23. Tocha Robacta Drive CMT da Fronius.

\subsubsection{Sistema de aquisição de dados para monitoramento dos sinais elétricos}

O monitoramento dos parâmetros, tais como: corrente e tensão de soldagem; aliado aos seus respectivos valores médios e tempos de atuação; foram adquiridos para que fossem analisados, com ajuda de um sistema de aquisição de sinais, o qual tem a função de acondicionar e isolar as variáveis elétricas do processo.

Deste modo, o sistema de aquisição de dados elétricos está composto por uma pinça amperimétrica Fluke i1010 CA/CC que utiliza o método do efeito hall para a medição da corrente com uma faixa de medição de $\pm 600 \mathrm{~A}$. Logo o voltímetro é conectado entre o eletrodo e a peça de trabalho a ser soldada (região de contato), o sensor possui um sistema de isolamento composto por um divisor de tensão, aplicado antes de ir para a placa de aquisição de sinais elétricos PCI Eagle 703s.

A visualização, o tratamento preliminar e o arquivamento dos sinais elétricos da corrente e da tensão da placa ocorrem por meio de um programa implementado no LabVIEW 2010, a uma taxa de $20 \mathrm{kHz}$. O tratamento dos dados coletados durante a realização dos testes foi realizado por meio do MATLAB, que permitiu avaliar, manipular e calcular os valores médios de tensão e corrente, bem como construir os gráficos dos sinais monitorados e finalmente utilizá-los como referência para calcular a potência de soldagem. 


\section{TESTES E RESULTADOS}

Neste capítulo são feitos os testes e logo apresentado os resultados encontrados, na sequência desde a $1^{a}$ até a $3^{a}$ etapa como representados na Fig. 1.1, para os processos de soldagem utilizados. Seguindo-se a metodologia experimental (Capítulo IV), bons cordões de solda de passe de raiz foram conseguidos, verificados por análise visual da face e da raiz de cada cordão. Assim, o seguinte passo para validar a metodologia e procedimentos usados neste trabalho foi realizar uma análise final, de macrografia, em cada etapa e para cada um dos processos de soldagem utilizados.

\subsection{Resultados da $1^{a}$ etapa - Ensaios preliminares}

Iniciou-se o estudo dos parâmetros de soldagem com base no trabalho de Aures [42] para o processo GMAW curto circuito derivativo. Ressalta-se que embora o chanfro, as chapas e espessura sejam diferentes, este trabalho aborda de forma similar os processos de soldagem utilizados, o que foi utilizado como ponto de partida. Com a intenção de avaliar a influência dos parâmetros do processo na geometria do cordão, para o processo GMAW-CMT, foram avaliados a influência do parâmetro comprimento do arco $\left(l_{a}\right)$ e da velocidade de Alimentação $\left(V_{a}\right)$.

Para isso, realizaram testes utilizando gás StarGold Plus com uma velocidade de soldagem ajustada em $30 \mathrm{~cm} / \mathrm{min}$, salientando que este parâmetro tem relação direita com a taxa de deposição $(T d)$, onde pôde ser modificada a variação de velocidade de soldagem e/ou a velocidade de alimentação $(T d=V a l / V$ sold $)$, observando a relevância na geometria do cordão, também com uma distância bico de contato peça $(\mathrm{DBCP})$ de $12 \mathrm{~mm}$, Variou-se então, $l_{a}$ de $-30,0$ e +30 (comprimento do arco, parâmetro da fonte CMT), como visto na Tabela 4.1.

Tabela 4.1. Aquisição para $V_{a}=4,5[\mathrm{~m} / \mathrm{min}]$ e $l_{a}=-30<0<+30$.

\begin{tabular}{|c|c|c|c|}
\hline & $l_{a} \mathbf{- 3 0}$ & $l_{a} \mathbf{0}$ & $l_{a}+\mathbf{3 0}$ \\
\hline$U_{m}[\mathbf{V}]$ & 13,7 & 13,58 & 14,53 \\
\hline$I_{m}[\mathbf{A}]$ & 181,23 & 186,32 & 181,93 \\
\hline
\end{tabular}


O perfil de onda da transferência CMT para a soldagem com a mistura StarGold Plus aplicada como gás de proteção apresentou certa semelhança com os descritos por Costa [3] que aplicou $\mathrm{C} 25\left(\mathrm{Ar}+25 \% \mathrm{CO}_{2}\right)$ como gás de proteção para a soldagem de aço ABNT 1020. Observando a Fig. 4.1 a frequência de curtos aumenta no sentido em que se aumenta o parâmetro comprimento do arco. Assim a corrente se tentou manter constante tendo a influencia desta frequência na deposição desta gota na poça de fusão a tensão fico variando em função disso.

Outra forma de observar a variação do comprimento de arco interfere na geometria do cordão, é fazendo um corte transversal(macrografia) nos cordões como é mostrado na Tabela 4.2. Por conseguinte, a medida que se aumenta o comprimento do arco, tendo fixo a taxa de deposição, a penetração e a largura aumentam na geometria do cordão.

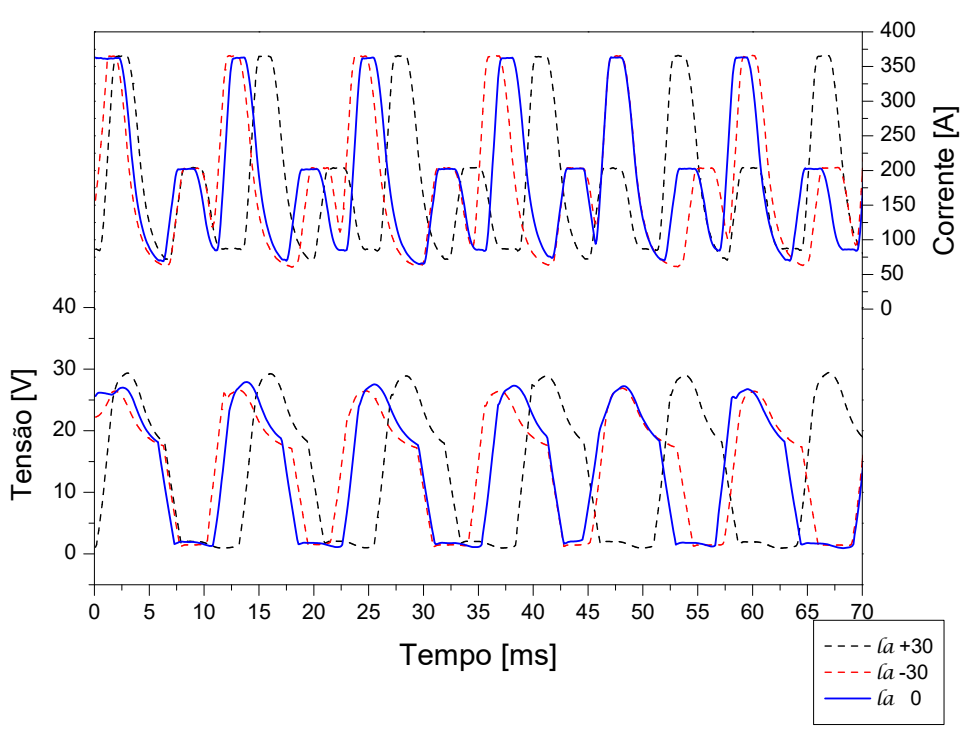

Figura 4.1. Oscilograma para $V_{a}=4,5[\mathrm{~m} / \mathrm{min}]$ e $l_{a}=-30<0<+30$.

Tabela 4.2. Seção transversal dos cordões de solda obtidos nesta etapa

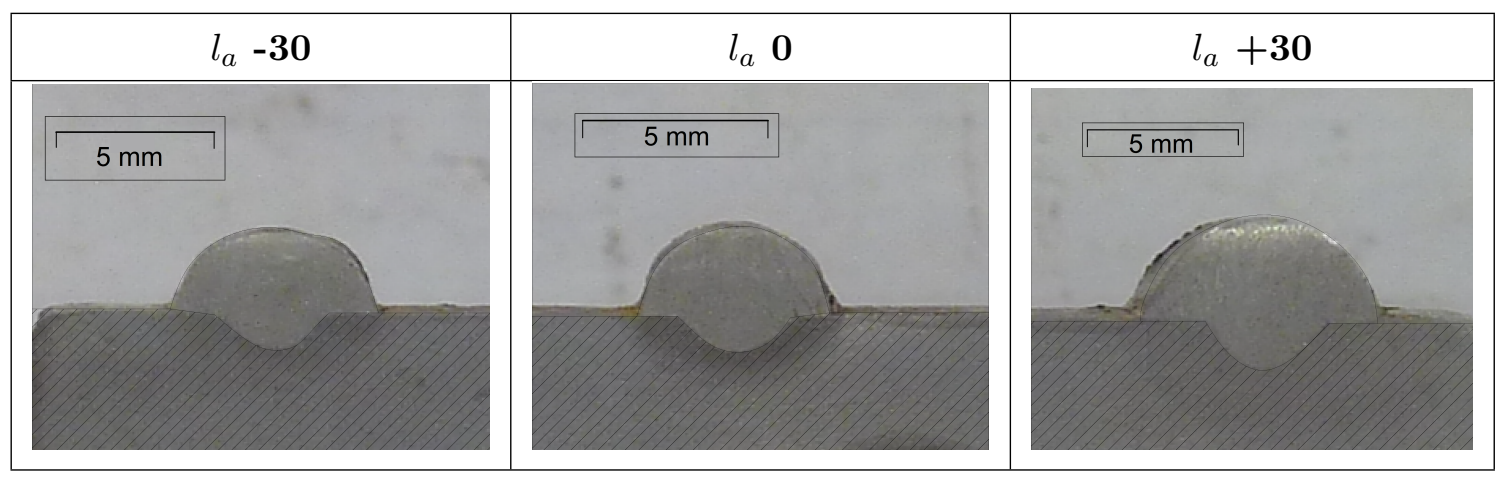

No teste seguinte para avaliar o efeito do parâmetro velocidade de alimentação $\left(V_{\text {alm }}\right)$, soldouse com o mesmo gás, a $\mathrm{Vs}=30 \mathrm{~cm} / \mathrm{min}$ e $l_{a}=0$ fixados, apenas variando velocidade de alimentação entre 4,1 4,5 e 4,9 [m/min]. Observa-se pela Tabela 4.3 os resultados lidos pela aquisição. 
Tabela 4.3. Aquisição para $l_{a}=0$ e $V_{a} 4,1<4,5<4,9$

\begin{tabular}{|c|c|c|c|}
\hline & $V_{a} \mathbf{4 , 1}[\mathrm{m} / \mathrm{min}]$ & $V_{a} \mathbf{4 , 5}[\mathrm{m} / \mathrm{min}]$ & $V_{a} \mathbf{4 , 9}[\mathrm{m} / \mathrm{min}]$ \\
\hline$U_{m}[\mathbf{V}]$ & 13,71 & 13,36 & 14,46 \\
\hline$I_{m}[\mathbf{A}]$ & 157,02 & 170,98 & 184,24 \\
\hline
\end{tabular}

Ao aumentar a velocidade de alimentação, a fonte CMT não parece mudar muito a frequência de curtos. Observa-se pela Figura 4.2 que a tensão varia pouco, mas que a corrente média se eleva notavelmente. Nota-se que Velocidade de alimentação tem efeito mais significativo na corrente do que na tensão, afirmando desta forma o encontrado na literatura.

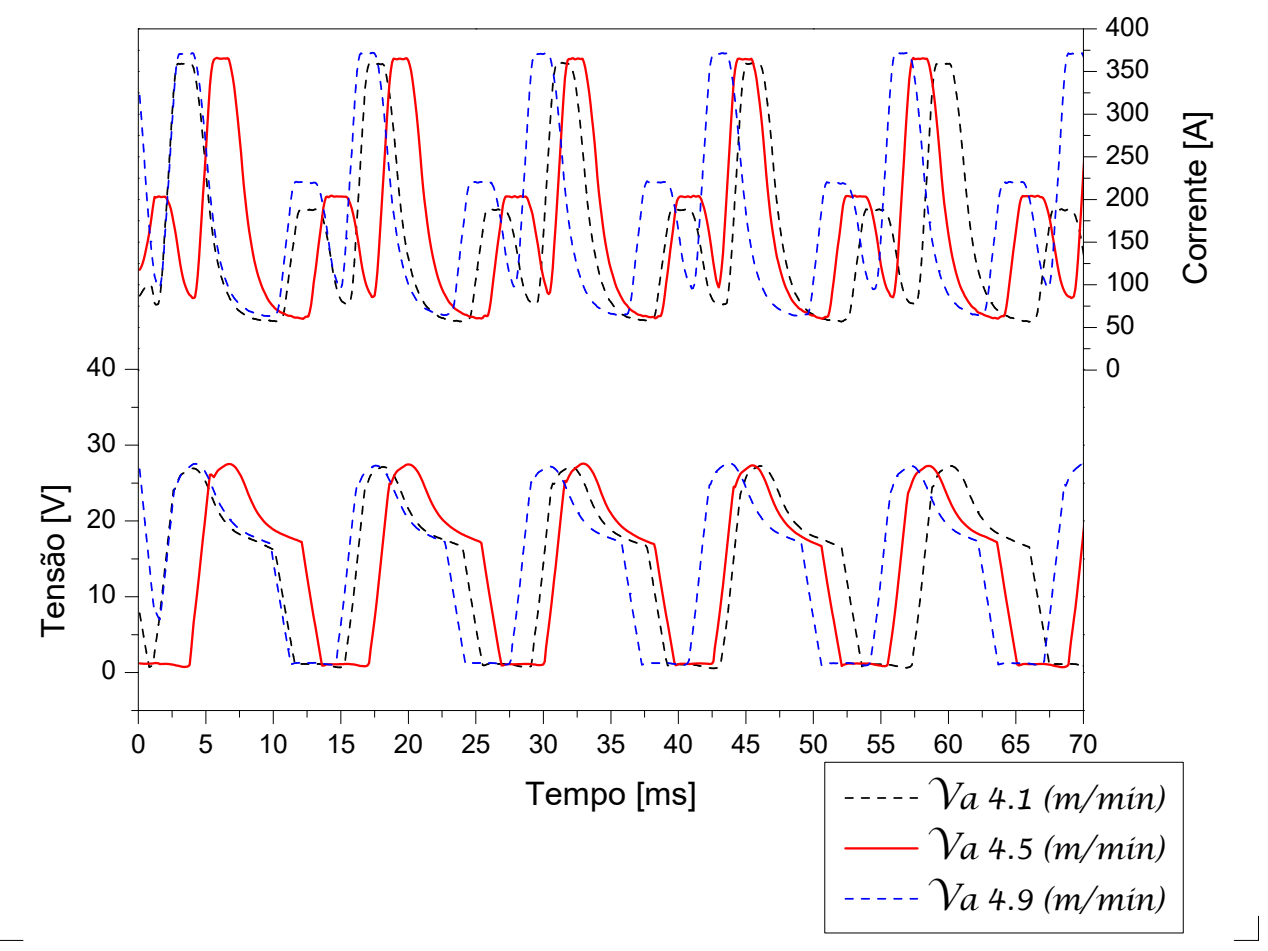

Figura 4.2. Oscilograma para $l_{a}=0$ e $V_{a} 4,1<4,5<4,9$

Consequentemente, uma vêz realizados o testes com deposição sobre chapas com a respetivas variações, foram encontrados os envelopes de trabalho, faixa entre valores mínimo, central e máximo dentro dos limites de regulagem das variáveis a fonte regular, obtendo uma boa estabilidade do cordão, sem respingos e sem defeitos internos, dando passo a montar o planejamento experimental como é mostrado na segunda etapa com chapas em chanfro estreito (passe de raiz nas três posições estabelecidas). 


\subsection{Resultados da $2^{a}$ etapa - Determinação da espessura de nariz para obter penetração completa em três posições críticas de soldagem.}

Com base na metodologia do Capítulo IV, serão apresentados e discutidos os resultados provenientes dos planejamentos experimentais utilizados: Metodologia de superfície de resposta $(M S R)$, com ajuda do arranjo Composto Central (CCD) e método Desirability para as três respostas em questão: penetração nas três posições de soldagem.

\subsubsection{Metodologia Experimental}

O planejamento experimental elaborado para o processo GMAW-CMT com os parâmetros já preestabelecidos pela Tabela 3.1. Com ajuda do programa Minitab®, montou-se um planejamento fatorial, considerando uma sequência aleatória para evitar erros sistemáticos. Na Tabela 4.4, têm os experimentos selecionados e especificam-se os valores correspondentes para cada variável.

Tabela 4.4. Experimentos selecionados

\begin{tabular}{|c|c|c|c|c|c|c|}
\hline \multirow{2}{*}{} & \multicolumn{3}{|c|}{ Níveis } & \multicolumn{3}{|c|}{ Faixa } \\
\cline { 2 - 7 } & $\mathrm{x} 1$ & $\mathrm{x} 2$ & $\mathrm{x} 3$ & $V_{a}(\mathrm{~m} / \mathrm{min})$ & $V_{s}(\mathrm{~mm} / \mathrm{s})$ & $l_{a}$ \\
\hline 1 & -1 & -1 & -1 & 4,1 & 4,5 & -15 \\
\hline 2 & 1 & -1 & -1 & 4,9 & 4,5 & -15 \\
\hline 3 & -1 & 1 & -1 & 4,1 & 5,5 & -15 \\
\hline 4 & 1 & 1 & -1 & 4,9 & 5,5 & -15 \\
\hline 5 & -1 & -1 & 1 & 4,1 & 4,5 & +15 \\
\hline 6 & 1 & -1 & 1 & 4,9 & 4,5 & +15 \\
\hline 7 & -1 & 1 & 1 & 4,1 & 5,5 & +15 \\
\hline 8 & 1 & 1 & 1 & 4,9 & 5,5 & +15 \\
\hline 9 & $-1,682$ & 0 & 0 & 3,82 & 5 & 0 \\
\hline 10 & 1,682 & 0 & 0 & 5,2 & 5 & 0 \\
\hline 11 & 0 & $-1,682$ & 0 & 4,5 & 4,25 & 0 \\
\hline 12 & 0 & 1,682 & 0 & 4,5 & 5,75 & 0 \\
\hline 13 & 0 & 0 & $-1,682$ & 4,5 & 5 & -30 \\
\hline 14 & 0 & 0 & 1,682 & 4,5 & 5 & +30 \\
\hline 15 & 0 & 0 & 0 & 4,5 & 5 & 0 \\
\hline
\end{tabular}


A Tabela 4.5, destaca os resultados dos experimentos indicados na Tabela 4.4, apresentada anteriormente, com a obtenção das medidas para penetração nas três posições de soldagem com a metodologia de nariz inclinada.

Tabela 4.5. Resultado dos experimentos do Desenho Central Composto

\begin{tabular}{|c|c|c|c|c|c|c|}
\hline \multirow{2}{*}{ No Exp } & \multicolumn{3}{|c|}{ Níveis } & \multicolumn{3}{|c|}{ Penetração $p^{\prime}(\mathrm{mm})$} \\
\cline { 2 - 7 } & $\mathrm{x} 1$ & $\mathrm{x} 2$ & $\mathrm{x} 3$ & Soldagem plana & Soldagem Vertical & Soldagem Sobrecabeça \\
\hline 1 & -1 & -1 & -1 & 2,5 & 2,3 & 2,2 \\
\hline 2 & 1 & -1 & -1 & 2,6 & 2,1 & 2,8 \\
\hline 3 & -1 & 1 & -1 & 2,2 & 2,4 & 1,8 \\
\hline 4 & 1 & 1 & -1 & 2,6 & 2,3 & 2,4 \\
\hline 5 & -1 & -1 & 1 & 2,3 & 1,9 & 2,7 \\
\hline 6 & 1 & -1 & 1 & 2,6 & 2,0 & 2,1 \\
\hline 7 & -1 & 1 & 1 & 2,8 & 1,9 & 2,2 \\
\hline 8 & 1 & 1 & 1 & 2,7 & 2,5 & 2,1 \\
\hline 9 & $-1,682$ & 0 & 0 & 2,6 & 2,1 & 2,5 \\
\hline 10 & 1,682 & 0 & 0 & 2,7 & 2,5 & 2,5 \\
\hline 11 & 0 & $-1,682$ & 0 & 2,4 & 2,0 & 2,4 \\
\hline 12 & 0 & 1,682 & 0 & 2,6 & 2,2 & 2,1 \\
\hline 13 & 0 & 0 & $-1,682$ & 2,4 & 2,2 & 2,3 \\
\hline 14 & 0 & 0 & 1,682 & 2,6 & 2,3 & 2,5 \\
\hline 15 & 0 & 0 & 0 & 2,7 & 2,3 & \\
\hline
\end{tabular}

\subsubsection{Realização dos Testes}

A fim de ficar mais clara a visualização da causa e efeito (parâmetro selecionado e aspecto do cordão de solda tanto na fase como na raiz), neste item será apresentada uma foto da forma como foi medida a penetração nas chapas planas com seu chanfro estreito nas três posições de soldagem, este foi por meio de uma amostra aleatória do planejamento apresentado na Tabela 4.4.

No primeiro caso apresentam as dificuldades no momento de fazer os teste do planejamento experiemntal, já que na deposição de passe de raiz com o processo de soldagem GMAW-CMT em chanfro estreito, por alguma razão, o cordão desvia na direção de umas das paredes (maior deposição sobre uma das paredes da junta), este comportamento parece ser devido ao menor aporte térmico deste processo, que não consegue aquecer as paredes da junta de forma uniforme, onde à medida que uma das paredes da junta aquece mais do que a outra, o arco tende a desviar transferindo a gota para esta parede, resultando no desvio do cordão. 
Durante a realização da soldagem, percebeu-se que os três cordões depositados sofreram desvios, sendo depositados em uma maior quantidade para um lado das paredes do chanfro, no entanto, a penetração foi conseguida mas é apresentada em uma pequena espessura de nariz. Na Fig. 4.3 é mostrada a face do cordão e como este apresenta o desvio depois da deposição, logo é mostrado na Fig. 4.4 onde o cordão não faz penetração completa aplicado a um conjunto de chapas com nariz constante de $2 \mathrm{~mm}$, como prova de penetração em posição plana, sendo descartado.

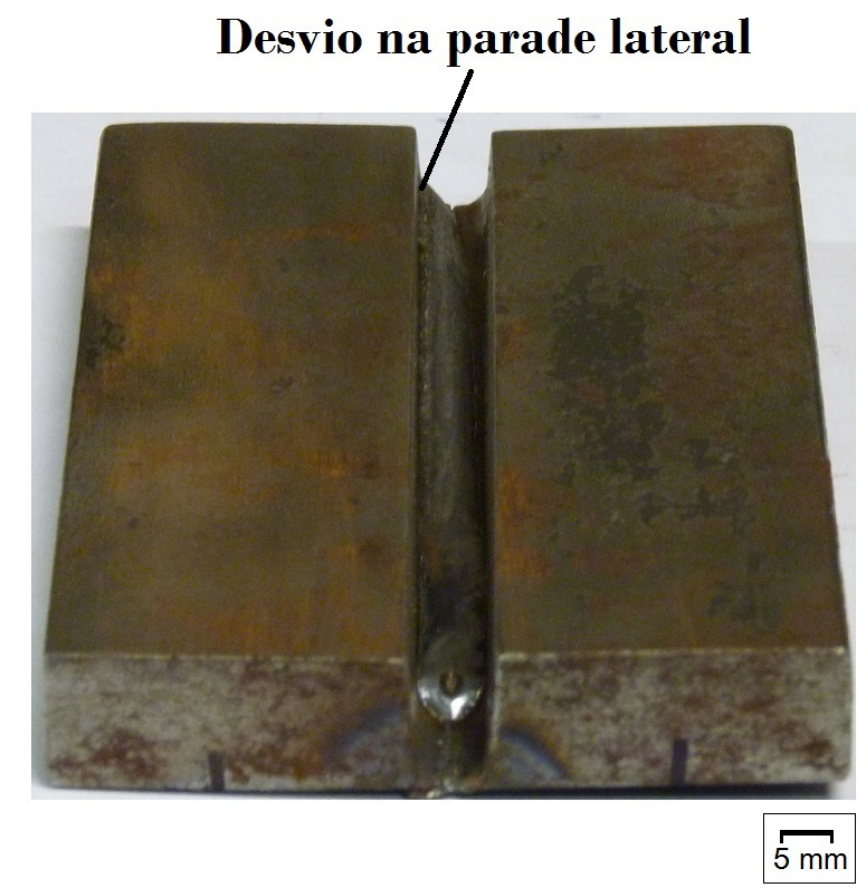

Figura 4.3. Teste com desvio do cordão em uma das paredes laterais.
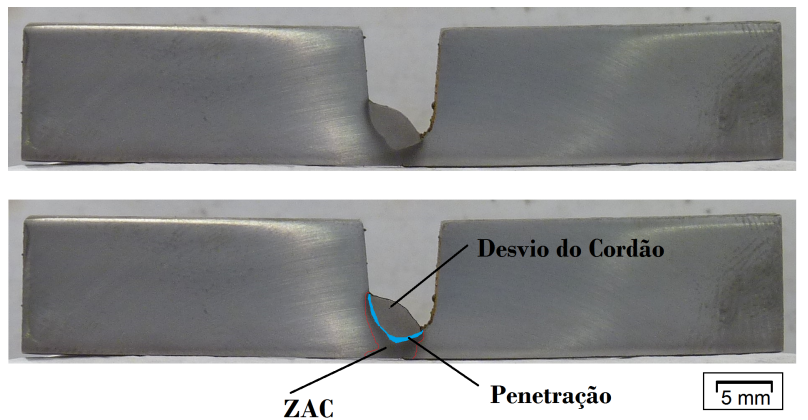

Figura 4.4. Representação de um cordão de solda desviado e sem penetração

Afim de resolver todos estes inconvenientes, posicionou-se o cabo terra a $180^{\circ}$ da solda, também realizou-se uma rigorosa programação do robô desde o ponto inicial até o ponto final nas três posições soldagem, um rigoroso controle dimensional das usinagens dos corpos de prova, e verificou-se que a abertura superior da junta se mantivera constante. 
A Fig. 4.5 apresenta a face e raiz do cordão depositado (ensaio realizado na posição plana), o teste CP07 correspondente ao experimento numero 7 do planejamento experimental, onde conseguiu-se completar a solda. Este não apresentou desvio para as paredes laterais, obtendo uma penetração em 2,8 $\mathrm{mm}$, nesta figura se amostra como foi tomada esta medida.
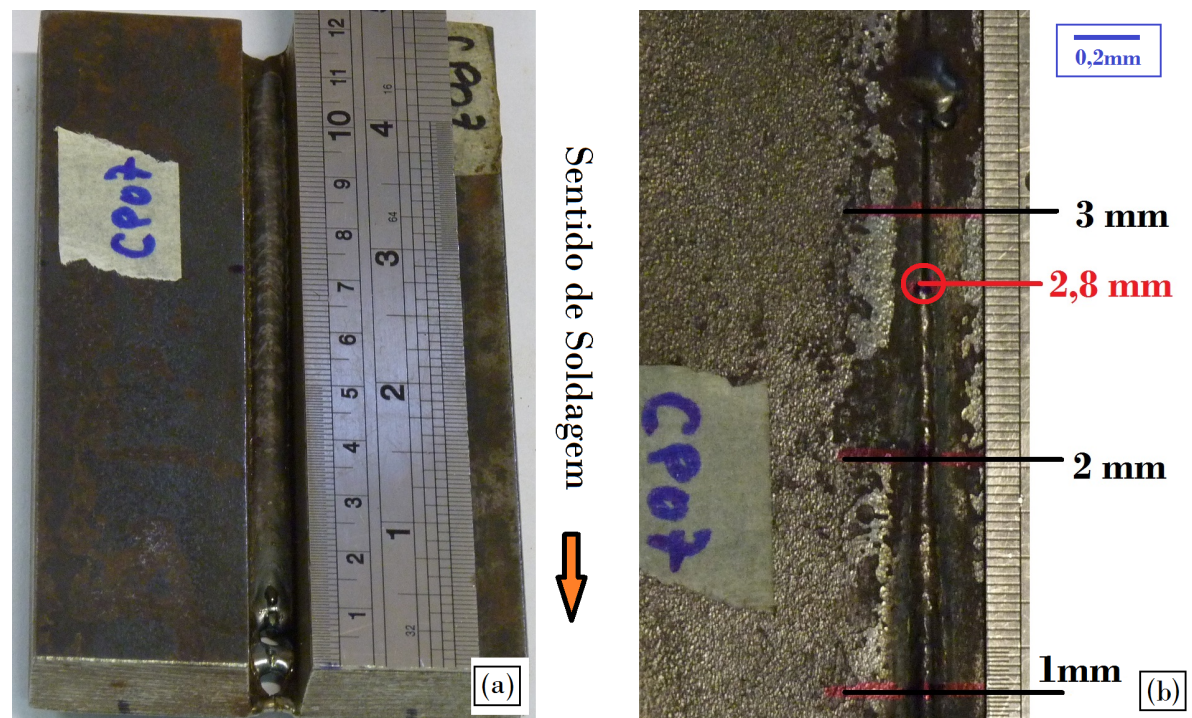

Figura 4.5. Teste de soldagem em posição plana com $V_{a}=4,1(\mathrm{~m} / \mathrm{min})$, $V_{s}=5,5(\mathrm{~mm} / \mathrm{s}), l_{a}=+16$. (a)face, (b)raiz.

Da forma idêntica foi avaliada a Fig. 4.6 onde apresenta um ensaio em posição vertical, com o teste CV12 que corresponde ao décimo segundo experimento em nesta posição, nesta posição apresentou-se pouca penetração. A maioria dos testes na mesma posição apresentou o mesmo fenômeno devido a força de gravidade ter uma grande influência, já que ela atua perpendicularmente a transferência da gota e na poça de fusão, o que proporciona uma tendência a se escorrer o metal fundido, portanto neste teste se obteve-se uma penetração de $2,2 \mathrm{~mm}$.
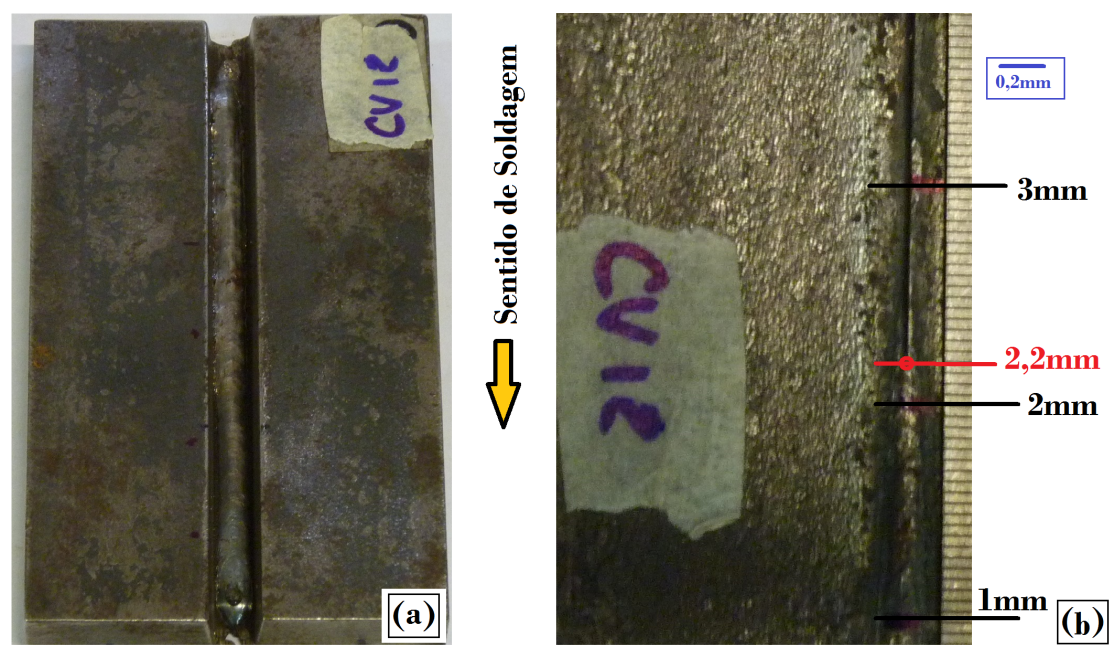

Figura 4.6. Teste de soldagem em posição vertical com $V_{a}=4,5(\mathrm{~m} / \mathrm{min})$, $V_{s}=5,75(\mathrm{~mm} / \mathrm{s}), l_{a}=0$. (a)fase, (b)raiz. 
Deste modo foi avaliada a Fig. 4.7 na qual apresenta um ensaio em posição sobrecabeça, com o teste CSC02, correspondente ao segundo teste do planejamento, nesta posição apresentou pouca penetração em comparação com a posição vertical. Assim, na posição sobrecabeça a gravidade age no sentido de dificultar o destacamento da gota e de fazer a queda do metal fundido, por conseguinte, este teste de soldagem apresentou uma penetração minima de $2,2 \mathrm{~mm}$ e sem desvio do cordão nas paredes laterais.
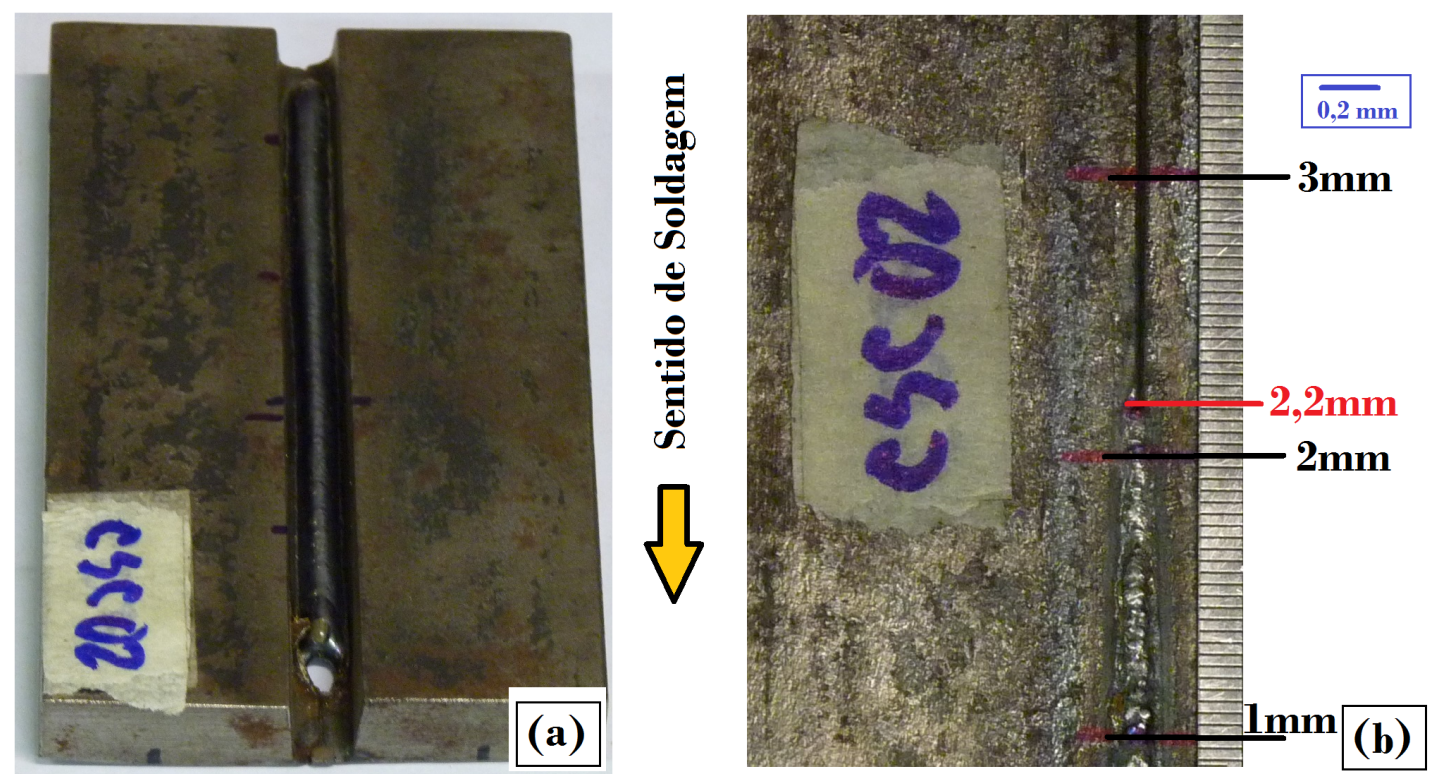

Figura 4.7. Teste de soldagem em posição sobrecabeça com $V_{a}=$ $4,9(\mathrm{~m} / \mathrm{min}), V_{s}=4,5(\mathrm{~mm} / \mathrm{s}), l_{a}=-15$. (a)fase, (b)raiz.

\subsubsection{Análise Estatística}

Com base nos resultados obtidos na Tabela 4.5, por meio de uma análise de regressão, usando o método dos mínimos quadrados [70], os coeficientes foram determinados a partir da Eq. 2.1, os cálculos realizados para fazer o análise da variância é das resposta com polinomial quadrático completo junto com os modelos de resposta de segunda ordem mostrado no anexo A. Salientando que os modelos matemáticos gerados para cada posição, foi utilizado a técnica (Forward) que consiste na seleção de variáveis por etapas. As variáveis são adicionadas uma de cada vez, até que um ajuste satisfatório é conseguido ou até que todos os preditores foram adicionados; no entanto, F-estatística são utilizadas em geral. Dado que estes F-estatística são baseados no princípio da redução da somas dos quadrados dos erros, eles medem a contribuição incremental de uma variável de previsão acima que é fornecida pelas variáveis já no modelo. Quando a adição de um preditor não resulta em uma F-estatística estatisticamente significativa, o procedimento é finalizado [109]. 


\section{- Posição Plana}

Para evidenciar o comportamento da velocidade de alimentação, velocidade de soldagem e o comprimento do arco, na penetração foi realizado um modelo e sua correspondente superfície de resposta. Os dados utilizados são apresentados na Tabela 4.5, o modelo é dado para os níveis codificados na Equação 4.1. Também é mostrada a superfície de resposta na Fig. 4.9 junto ao grafo de resíduos nesta posição de soldagem Fig. 4.8.

$$
\hat{y} p^{\prime} p=-6,39+0,1742 V_{a}+3,19 V_{s}-0,0838 l_{a}-0,308 V_{s} * V_{s}-0,000186 l_{a} * l_{a}+0,01733 V_{s} * l_{a}
$$

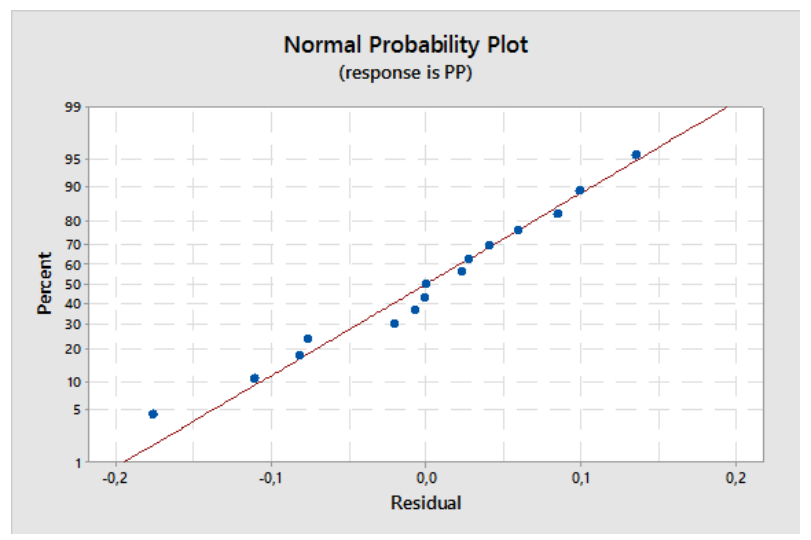

Figura 4.8. Probabilidade normal VS Resíduos para penetração em posição plana.

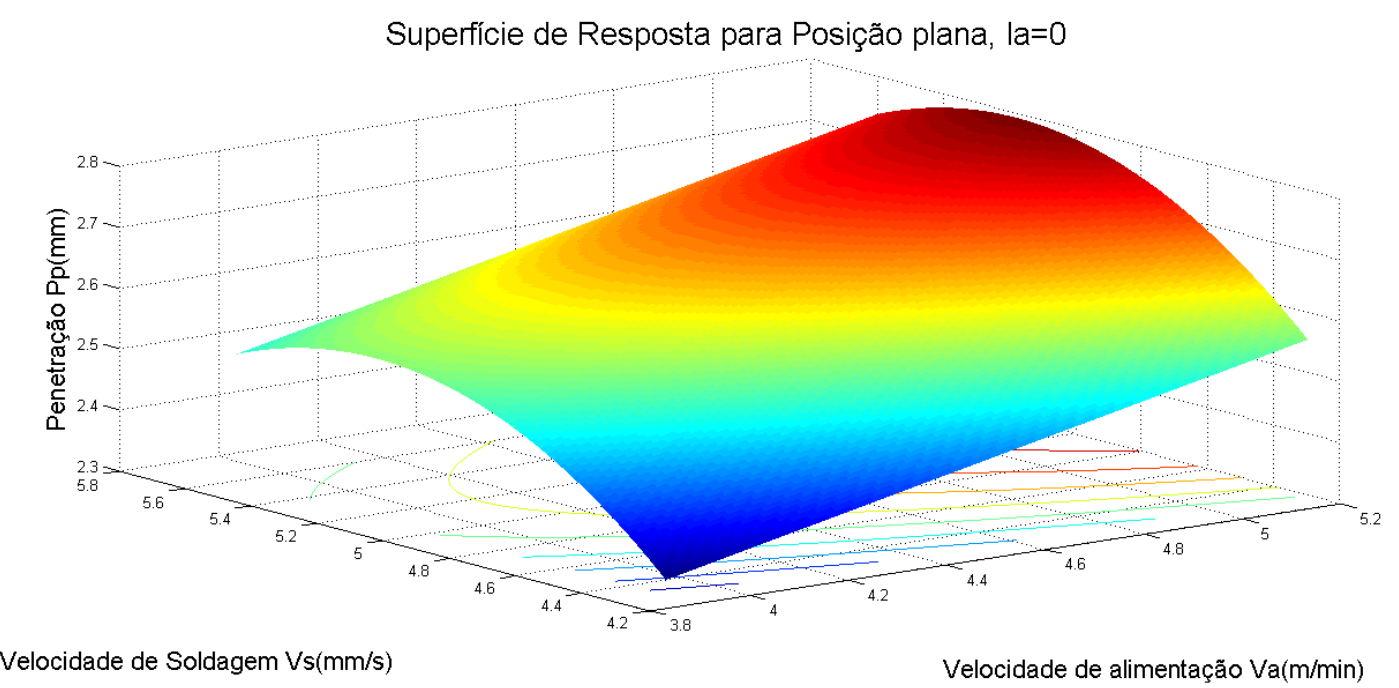

Figura 4.9. Superfície de resposta para o modelo de penetração em posição plana.

O gráfico de probabilidade normal possibilita observar uma boa correspondência do modelo matemático, já que os resíduos são distribuídos ao longo da linha reta que forma a distribuição 
normal Fig. 4.8. No gráfico de superfície de resposta mostrado na Fig. 4.9 tem um comportamento de segunda ordem, tendo como variável constante o comprimento do arco em 0 , este gráfico descreve que em medida que a velocidade de alimentação do arame aumenta se tem uma maior penetração.

\section{- Posição Vertical}

Nesta posição fez-se o mesmo tratamento que no anterior, mostrando o comportamento dos fatores na penetração, apresentando o modelo matemático ajustado para níveis codificados na Equação 4.2, como os outros gráficos para avaliar seu respetivo comportamento.

$$
\hat{y} p^{\prime} v=2,03-1,906 V_{a}+1,42 V_{s}-0,0957 l_{a}-0,314 V_{s} * V_{s}+0,425 V_{a} * V_{s}+0,02083 V_{a} * l_{a}
$$

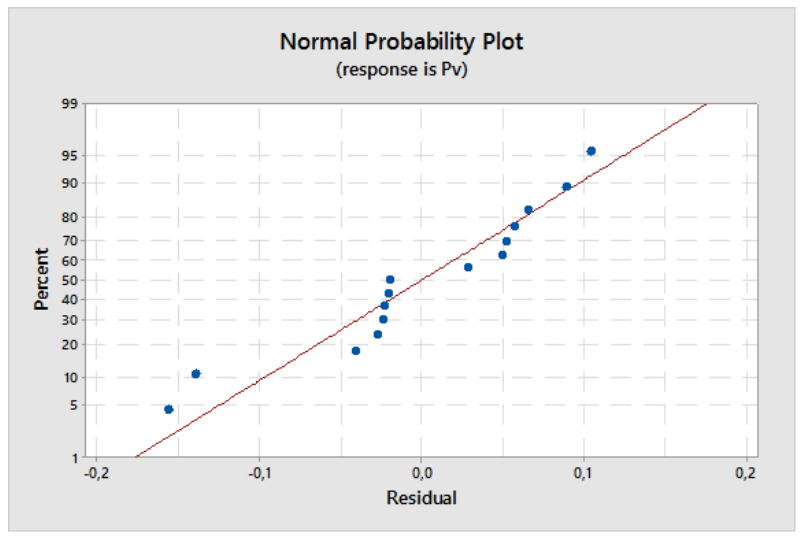

Figura 4.10. Probabilidade normal VS Resíduos para penetração em posição vertical.

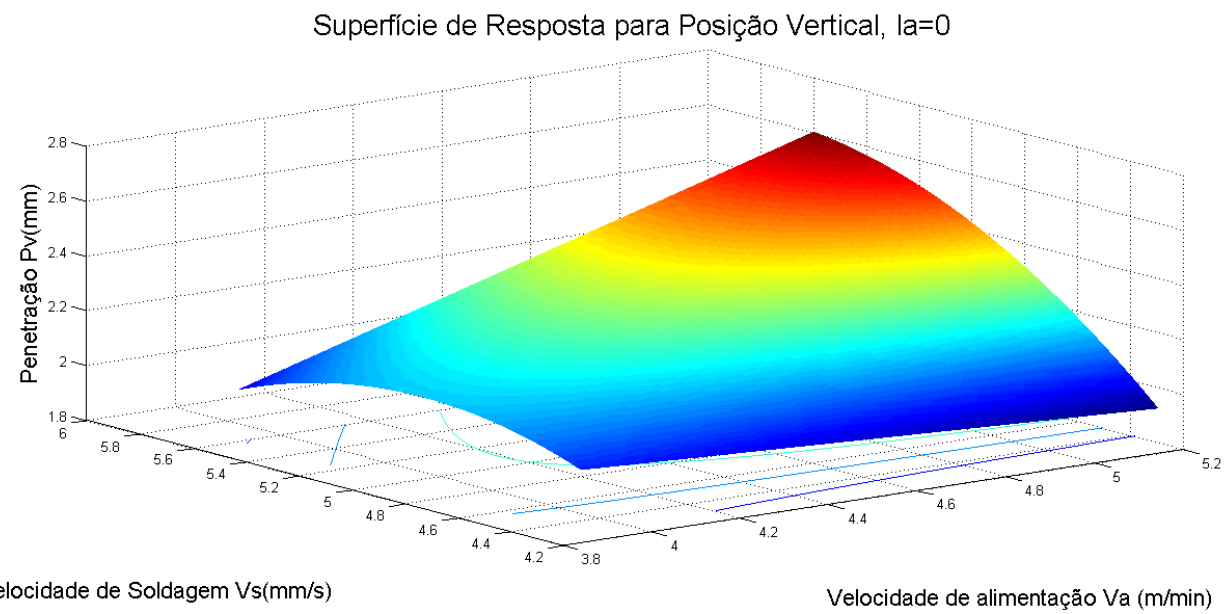

Figura 4.11. Superfície de resposta para o modelo de penetração em posição

Vertical. 
O gráfico de probabilidade normal apresenta uma boa correspondência ao modelo matemático gerado, os resíduos são distribuídos na linha reta que forma na distribuição normal Fig.4.10, logo no gráfico de superfície de resposta mostrado na Fig. 4.11 neste gráfico apresenta que a medida que a velocidade de alimentação do arame aumenta a penetração tende a aumentar.

\section{- Posição Sobrecabeça}

Do mesmo modo, fez-se o analise na posição sobrecabeça, apresentando o modelo matemático ajustado para níveis codificados por meio da equação 4.3, junto com o gráfico de probabilidade normal vs resíduos e superfície de resposta.

$$
\hat{y} p^{\prime} s c=2,686+0,1870 V_{a}-0,2312 V_{s}+0,1759 l_{a}-0,000229 l_{a} * l_{a}-0,03875 V_{a} * l_{a}
$$

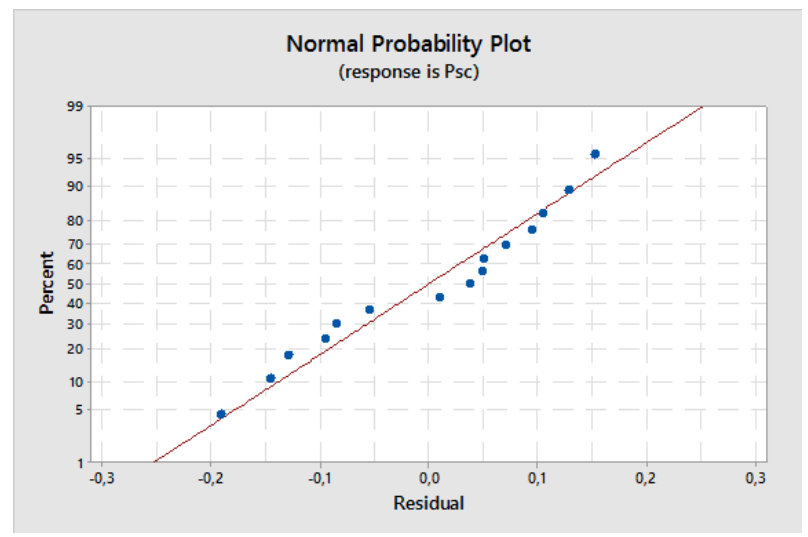

Figura 4.12. Probabilidade normal VS Resíduos para penetração em posição Sobrecabeça.

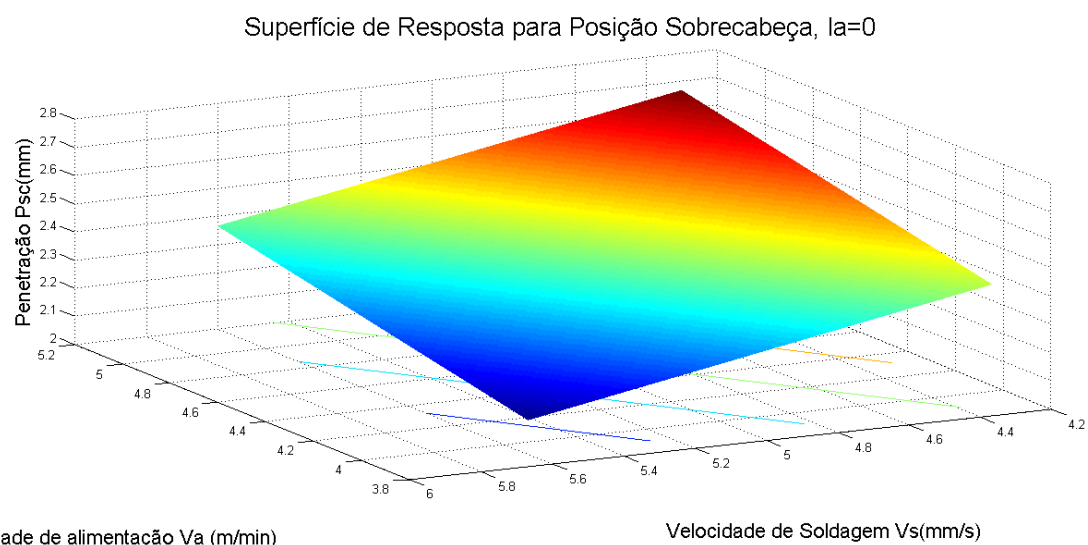

Figura 4.13. Superfície de resposta para o modelo de penetração em posição Sobrecabeça.

O gráfico de probabilidade normal apresenta uma boa correspondência ao modelo matemático gerado segundo a Fig.4.12, por tanto, no gráfico de superfície de resposta apresentado na Fig. 4.13 
representa um modelo de primeira ordem, já que observa-se que sua superfície é um plano, neste gráfico se observa que a menor penetração foi atingida com uma velocidade de de $5,4(\mathrm{~mm} / \mathrm{s})$ e a medida que a velocidade de alimentação do arame aumenta a penetração tende a ser maior.

Uma vez gerados os três modelos matemáticos com seus respetivos gráficos na penetração com a metodologia de nariz decrescente, faz-se uma otimização utilizando a Teoria de Desirability, para obter uma espessura de nariz que cumpra uma penetração completa nestas posições críticas.

\section{- Implementação do método Desirability}

Para implementar o método Desirability, proposto por Derringer e Surich, foi necessário estabelecer o valor alvo especificado, este valor foi escolhido de $2,3 \mathrm{~mm}$ de penetração, já que no momento da realização dos testes foi quem apresentou melhor estabilidade sem desvios nas paredes e com um bom aporte de solda, conforme os valores são apresentados na Tabela. 4.6.

Tabela 4.6. Valor alvo especificado dos parâmetros do processo GMAW-

CMT com Chanfro estreito em U.

\begin{tabular}{|c|c|}
\hline Respostas & Alvo \\
\hline Penetração plana p'p $(\mathrm{mm})$ & 2,3 \\
\hline Penetração Vertical p'v $(\mathrm{mm})$ & 2,3 \\
\hline Penetração Sobrecabeça p'sc $(\mathrm{mm})$ & 2,3 \\
\hline
\end{tabular}

Aplicando o Desirability sobre as respostas obtidas no experimento, através da formulação de transformação bilateral, onde se conhecem os valores alvo, chegou-se a uma combinação de parâmetros que satisfez todas as condições de otimização desejadas. A Tabela 4.7 apresenta os resultados alcançados para os três fatores experimentais em estudo.

Tabela 4.7. Resultados dos fatores experimentais para obter penetração completa nas posições críticas de soldagem estabelecidas.

Fatores Experimentais

Velocidade de alimentação Velocidade de soldagem Comprimento do Arco

do arame $\mathrm{Va}(\mathrm{m} / \mathrm{min}) \quad \mathrm{Vs}(\mathrm{mm} / \mathrm{s}) \quad$ la

4,7289

5,750

$-16,5215$ 


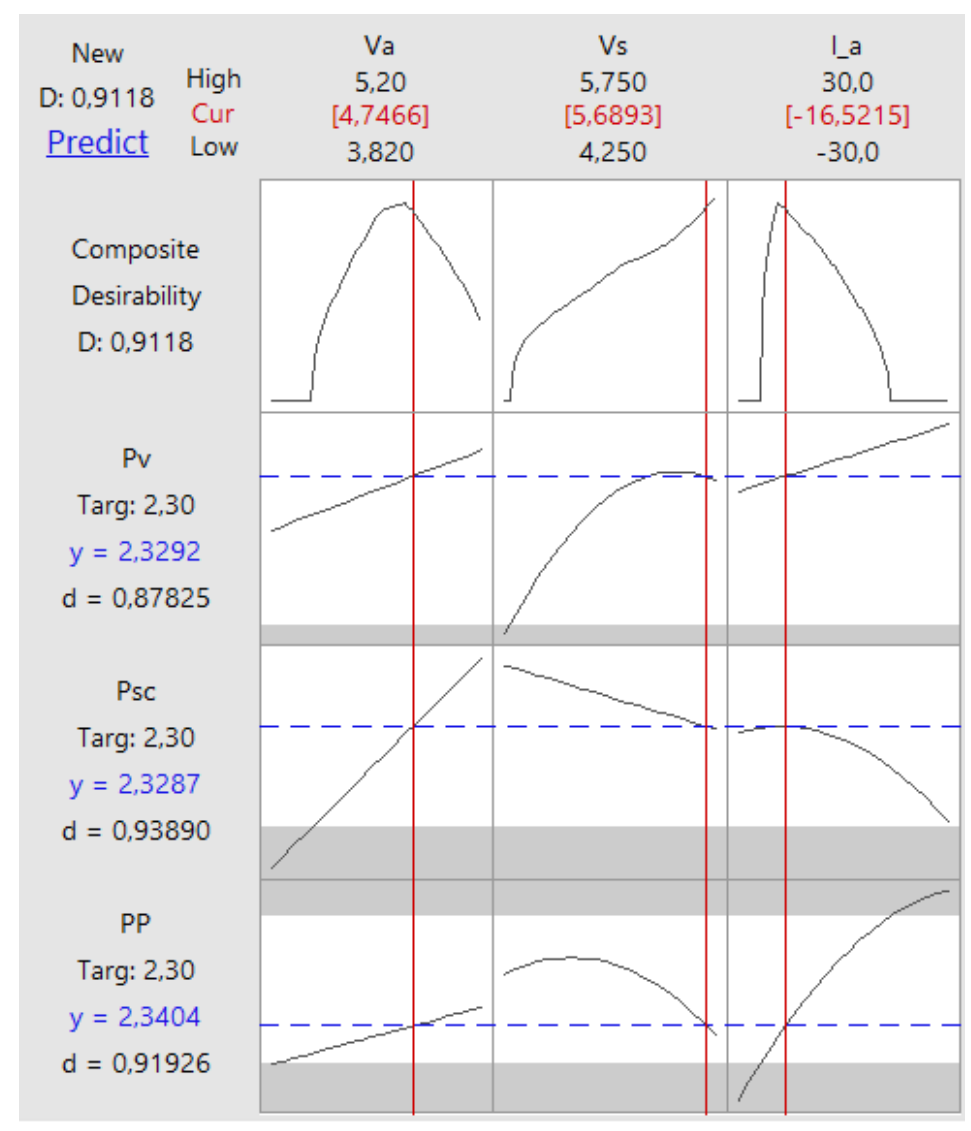

Figura 4.14. Individualização de otimização Desirability

O problema é resolvido por meio de conveniência composta. Obtive-se um valor de conveniência composta de $D=0,9188$, para obter um ajuste fatores que otimizam todas as variáveis de resposta. Os fatores de definição são mostrado na Fig 4.14. Pode-se observar que o Desirability individual em posição sobrecabeça ficou melhor em comparação as outras duas, com um valor de $d=0,9389$, com os valores obtidos na Tabela 4.7 procedeu-se novamente a fazer os ensaios com a espessura de nariz de $2,3 \mathrm{~mm}$ constante, obtendo uma nova geometria da junta para validar a otimização por meio da Teoria de Desirability em chapas planas de aço ABNT 1020.

\subsubsection{Validação da Otimização Desirability}

Uma vez feito a otimização do planejamento por meio da teoria Desirability, tendo os parâmetros de regulagem da Tabela 4.14 faz-se a validação em uma junta de soldagem com chanfro estreito com nariz constante de 2,3 mm aplicado nas três posições de soldagem. Na Fig 4.15 é mostrado como foi o resultado final da face e raiz na deposição do cordão de solda, desta forma considerando o apropriado para se utilizado na execução de soldagem de topo. 

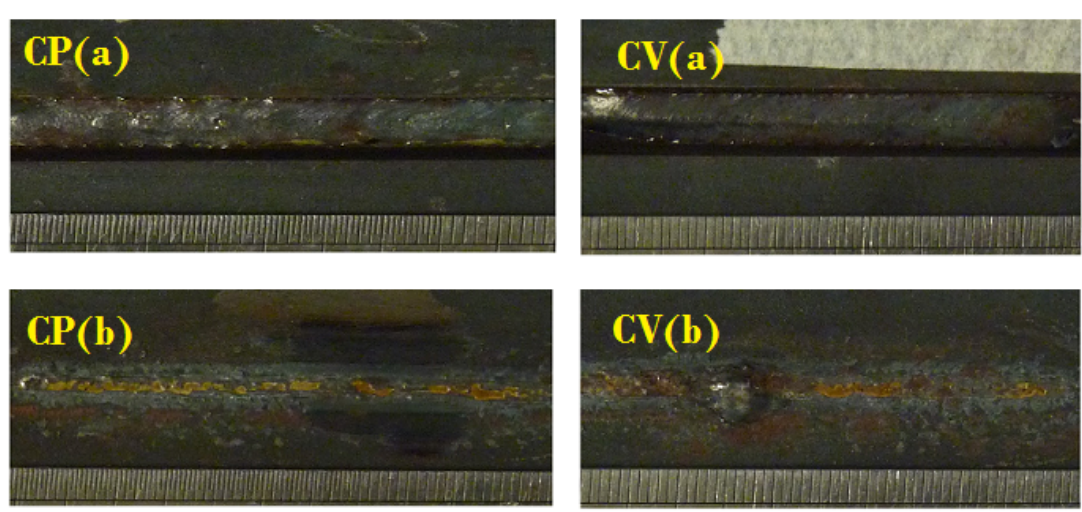
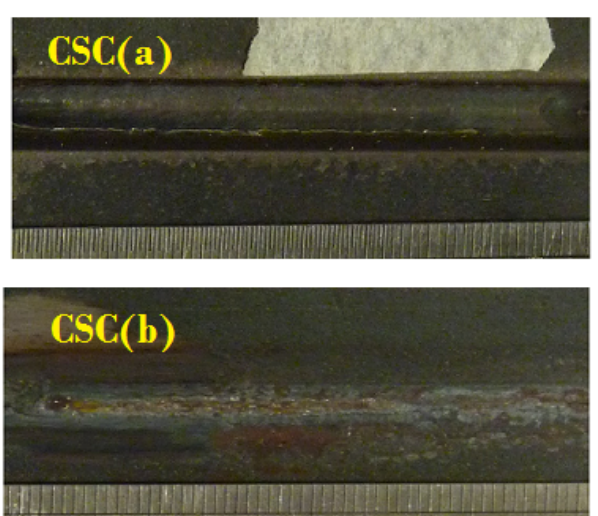

Figura 4.15. Aspectos (a) da face e (b) da raiz dos cordões de solda obtidos em juntas de chanfro estreito no processo de simulação com nariz de 2,3 mm, sem cobre-junta.

Pode-se verificar na Fig. 4.15 que o cordão apresenta uma boa face, sem desvios obtendo penetração total e homogênea ao longo do comprimento.

Da Fig. 4.16, pode-se ver primeiramente que a seção transversal do cordão, nestas três posições não apresenta defeitos internos. As faces nas posições CP(plana) e CSC(Sobrecabeça) apresentam um formato pequeno convexidade em um lado, mas acredita-se que não tenha maior influência quando o próximo passe seja depositado, e na posição CV(Vertical) nota-se uma boa face. Logo na raiz em CP e CV apresentou um bom reforço e em CSC mostrou uma penetração completa.
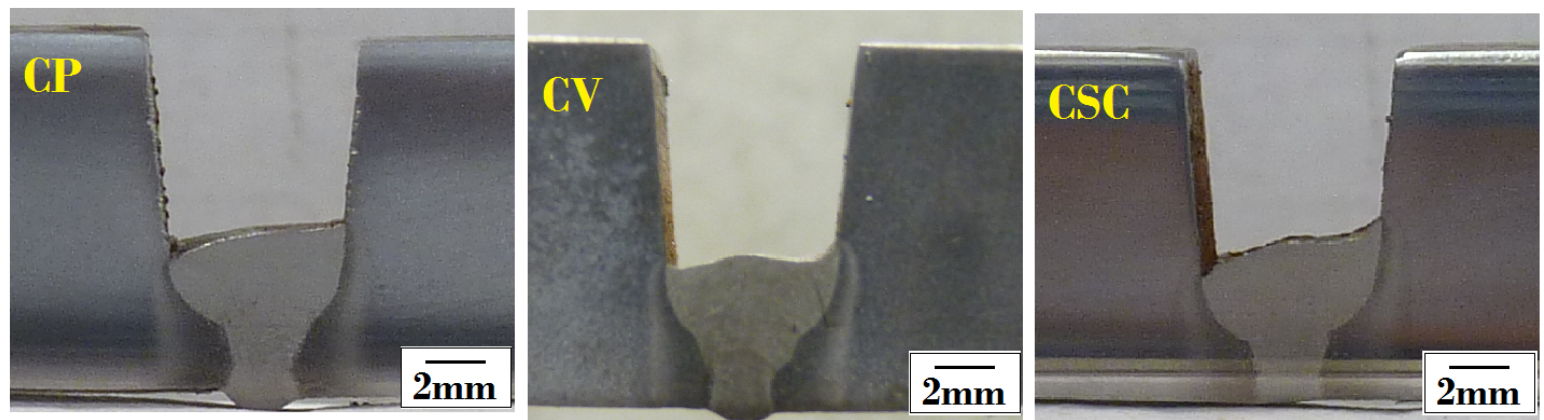

Figura 4.16. Seção transversal do cordão, realizado com o processo de validação em junta sem cobre-junta, em pontos onde se encontram as posições $\mathrm{CP}, \mathrm{CV}$ e CSC, com GMAW-CMT

Uma vez comprovado os parâmetros para obter penetração completa nestas três posições, com a configuração de junta de chanfro estreito sem cobre-junta obteve-se uma boa geometria do cordão de solda, assumindo que estas posições críticas são as correspondentes de uma soldagem orbital de meia cana, fez-se a validação com um tubo de 12 polegadas de diâmetro. 


\subsection{Resultados da $3^{a}$ etapa - Validação da soldagem Orbital}

Uma vez concluídas as duas primeiras etapas, com os parâmetros já definidos para obter uma boa geometria do cordão, na união de duas chapas com junta de chanfro estreito em U sem cobre-junta, com uma mesma espessura de raiz(Geometria da junta), aplicado o passe de raiz nas três posições se procede a fazer esta validação em tubos.

Em relação ao equipamento de soldagem circunferencial (Tartílope V4), localizado no laboratório GRACO, por ser o primeiro protótipo desenvolvido por LABSOLDA/UFSC, houveram dificuldades quanto ao seu no funcionamento, tanto na parte mecânica, estrutural, como na parte de software. No decorrer desta etapa, o equipamento não conseguiu efetuar a validação da $3^{a}$ etapa. Por tanto, por meio de uma pareceria com o laboratório LRSS da UFMG se fizeram os testes de validação em soldagem tubular, assim, neste laboratório colocaram a disponibilidade uma fonte convencional Fig. 3.22 junto com o cabeçote de soldagem orbital Fig. 3.19.

Consequentemente, apresentou-se uma grande dificuldade com respeito ao acondicionamento dos parâmetros encontrado nas duas primeiras etapas, já que eram dirigidas ao processo GMAWCMT, na validação teve-se como referencia a geometria final obtida na junta de chanfro estreito em U com uma espessura de nariz construído de $2,3 \mathrm{~mm}$, e os parâmetros gerais de velocidade de alimentação(corrente), comprimento de arco(Tensão) e velocidade de alimentação de soldagem usado no planejamento de cada posição, como ponto incial dos testes. Os tubos foram cortados, usinados, chanfrados segundo o procedimento experimental Fig. 3.18. Nesta validação se fez uma comparação de dois arames sólidos de diâmetros mostrados na Tabela 3.3 (0.9 e 1,2 mm de diâmetro) com o objetivo de fazer uma comparação na energia de soldagem com respeito ao utilizado nas duas primeiras etapas.

\subsubsection{Teste com arame de 0,9 $\mathrm{mm}$ de diâmetro}

Com este arame faz-se os testes no tubo chanfrado com os parâmetros finais obtidos na otimização Tabela 4.7, assumindo que vai usar o mesmos na soldagem de meia cana do tubo. Fez-se a deposição de solda na superfície obtendo como resultado uma geometria diferente em cada posição como é mostrado na Fig. 4.17, isto é devido a que os testes feitos com a fonte CMT obtém-se um controle na corrente e na tensão mais preciso que em uma fonte convencional além de utilizar a mesma energia de soldagem.

Na Fig. 4.17 pode-se observar que na posição plana apresenta uma boa geometria junto com a vertical, mas na posição sobrecabeça ele apresenta uma convexidade elevada, fazendo com que a geometria superficial do cordão não seja igual na superfície do tubo. 


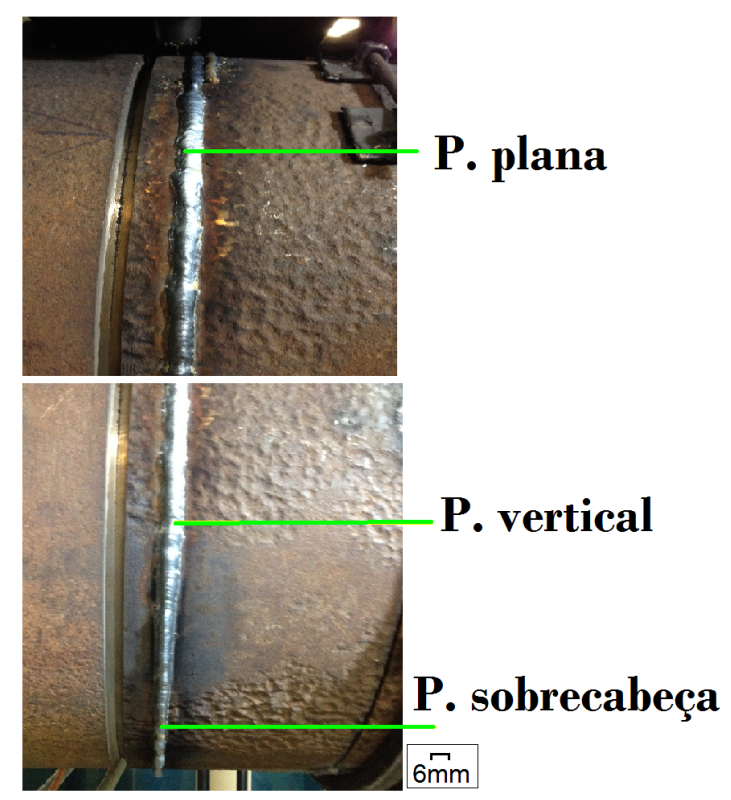

Figura 4.17. Soldagem orbital com arame de $0,9 \mathrm{~mm}$ de diâmetro e com parâmetros de otimização Desirability

Posteriormente foi realizado uma simulação de chanfro estreito por meio de cordões um em cima do outro, com um afastamento de 6,5 $\mathrm{mm}$ no meio deles, se construiu a configuração da junta com a ajuda de uma esmeriladeira como é mostrada na Fig. 4.18(a).
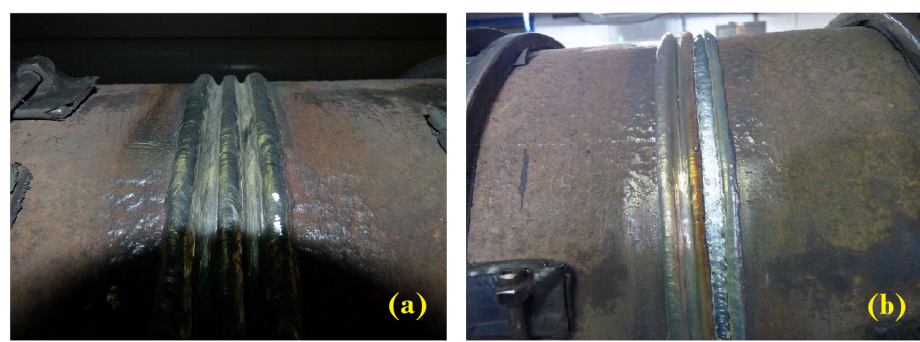

Figura 4.18. (a) Simulação do chanfro com cordões sobrepostos, (b) aspecto visual do cordão depositado na simulação do chanfro para um arame de 0,9 mm de diâmetro

Na 4.18(b) observa-se que o cordão depositado teve um bom aspeto visual, já que não houve nenhum desvio em uma de suas paredes laterais, as condições utilizadas para este tipo de arame na aplicação do passe de raiz do tubo foram:

- $\mathrm{DBCP}=10 \mathrm{~mm}$, teve-se que diminuir em comparação com o utilizado nas duas primeiras etapas, já que esta distância tem uma relação direita com a tensão e corrente, consequentemente com a taxa de fusão.

- Gás de proteção $=\mathrm{Ar}+25 \% \mathrm{CO}_{2}$ com vazão de $16 \mathrm{l} / \mathrm{min}$.

- Ângulo da tocha com respeito na poça de soldagem $90^{\circ}$. 
Para fazer a soldagem em passe de raiz no tubo com chanfro estreito, variaram-se os parâmetros de corrente, tensão e velocidade de soldagem no deslocamento da tocha, estes parâmetros são mostrados na Tabela 4.8. Como se pode ver na tabela a velocidade de soldagem esta na faixa do planejamento, os parâmetros corrente e tensão deste processo, são relacionados com os utilizados na otimização Desirability.

Tabela 4.8. Parâmetros para soldagem de tubos com o processo curtocircuito convencional com arame de $0,9 \mathrm{~mm}$ de diâmetro para Passe de raiz

\begin{tabular}{|c|c|c|c|}
\hline \multirow{2}{*}{ Posição } & \multicolumn{3}{|c|}{ Parâmetros do processo de soldagem em meia cana descendente } \\
\cline { 2 - 4 } & Corrente $[\mathrm{A}]$ & Tensão [V] & Velocidade de Soldagem $[\mathrm{mm} / \mathrm{s}]$ \\
\hline Plana & $139-166$ & $18,2-18,8$ & 4,5 \\
\hline Vertical & $159-178$ & $18,3-18,9$ & 4,0 \\
\hline Sobrecabeça & $159-176$ & $18,4-18,9$ & 3,9 \\
\hline
\end{tabular}

A soldagem foi efetuada, considerando todos os parâmetros estabelecidos. A Fig. 4.19, mostra a face do cordão depositado nos tubos, nas posições: plana; vertical e sobrecabeça, observando que o cordão apresentou uma boa geometria sem desvio em umas das paredes laterais do chanfro estreito, como representado na Fig. 3.20.

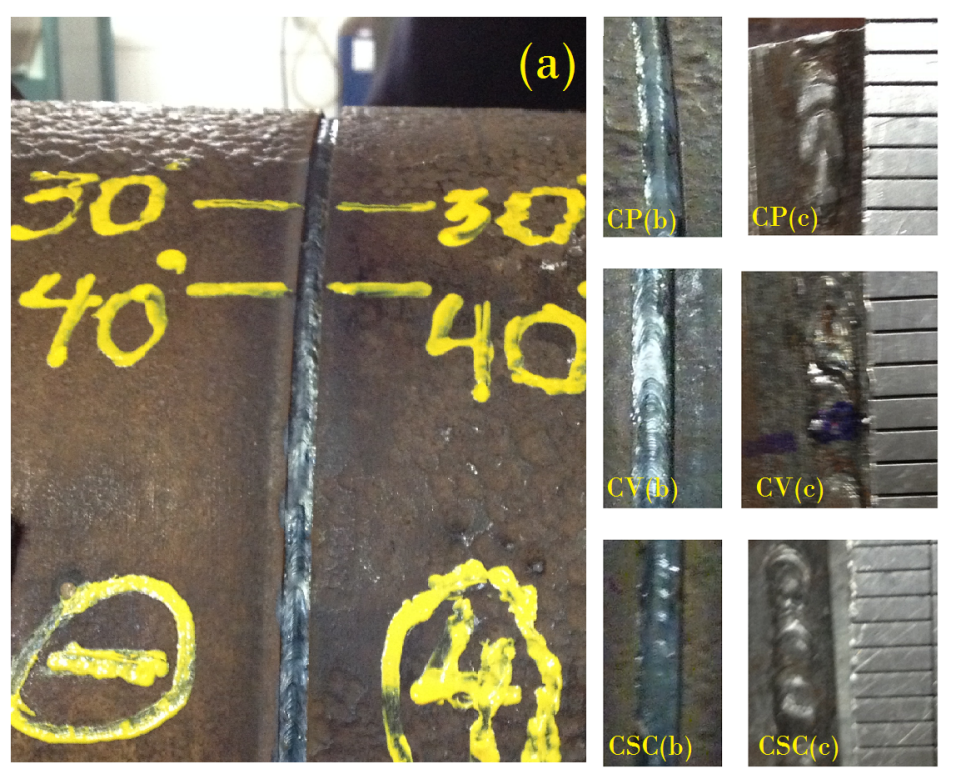

Figura 4.19. (a)Formato da face do cordão obtido no processo de soldagem orbital com arame de 0,9 mm de diâmetro, sem cobre-junta, com espessura de nariz de 2,3 mm, para o processo curto-circuito convencional),(b)face, (c)raiz.

Uma análise de macrografia foi realizada para verificar a seção transversal do cordão sem defeitos internos. O cordão depositado foi cortado obtendo os corpos de prova segundo o posicionamento da Fig. 3.20. As seções transversais destas posições são mostradas na Fig. 4.20. 

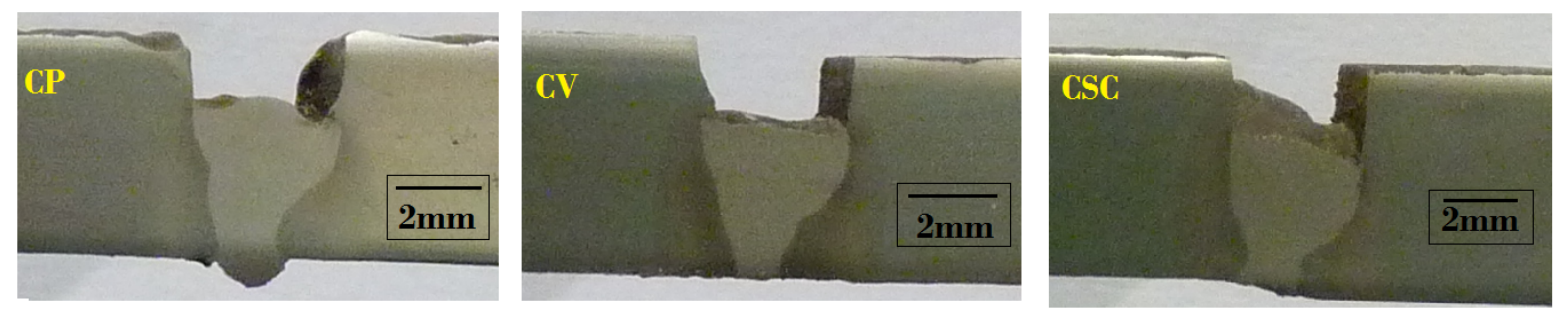

Figura 4.20. Seção transversal da soldagem orbital, com o curto-circuito convencional com arame de 0,9 $\mathrm{mm}$ de diâmetro, em pontos onde as posições são plana, vertical e sobrecabeça.

Da Fig. 4.20, pode-se ver primeiramente que a seção transversal do cordão, nestas três posições porém, não apresenta defeitos internos. A face na posição $\mathrm{CP}$ (plana) apresenta um formato convexo, mas acreditase que este não tenha muita influência no próximo passe, em $\mathrm{CV}$ (Vertical) apresenta-se um bom formato na face e na raiz, mostrando uma penetração completa sem reforço, finalmente CSC(sobrecabeça) pode-se ver que nesta secção há um pequeno desalinhamento, sendo assim nesta posição apresentou uma boa face do cordão e uma penetração completa sem reforço de raiz.

\subsubsection{Teste com arame de 1,2 $\mathrm{mm}$ de diâmetro}

Nesta fase também apresenta-se dificuldade no momento de utilizar os parâmetros da otimização Desirability da segunda etapa, já que o cordão depositado não apresenta uma boa face e não tinha a mesma geometria na deposição de solda em meia cana descendente do tubo. Seguindo a metodologia de simulação de chanfro com deposições de cordões um sobre outros e esmerilando a abertura $6,5 \mathrm{~mm}$, fez-se um aumento dos parâmetros (tensão e corrente) com respeito ao anterior arame, por ser de maior diâmetro, precisando de uma maior taxa de fusão, a Fig. 4.21(a) representa a simulação do chanfro com o posicionamento da tocha, e na Fig. 4.21(b) o teste mostra uma boa face do cordão com duas repetições, para usar na união dos tubos com o chanfro estreito. As condições utilizadas para este tipo de arame na aplicação do passe de raiz do tubo foram:

- $\mathrm{DBCP}=14 \mathrm{~mm}$, teve-se que aumentar em comparação com o utilizado no arame anterior por ter um diámetro maior e precisar mais taxa de fusão.

- Gás de proteção $=\mathrm{Ar}+25 \% \mathrm{CO}_{2}$ com vazão de $16 \mathrm{l} / \mathrm{min}$.

- Ângulo da tocha com respeito a poça de soldagem $90^{\circ}$ 

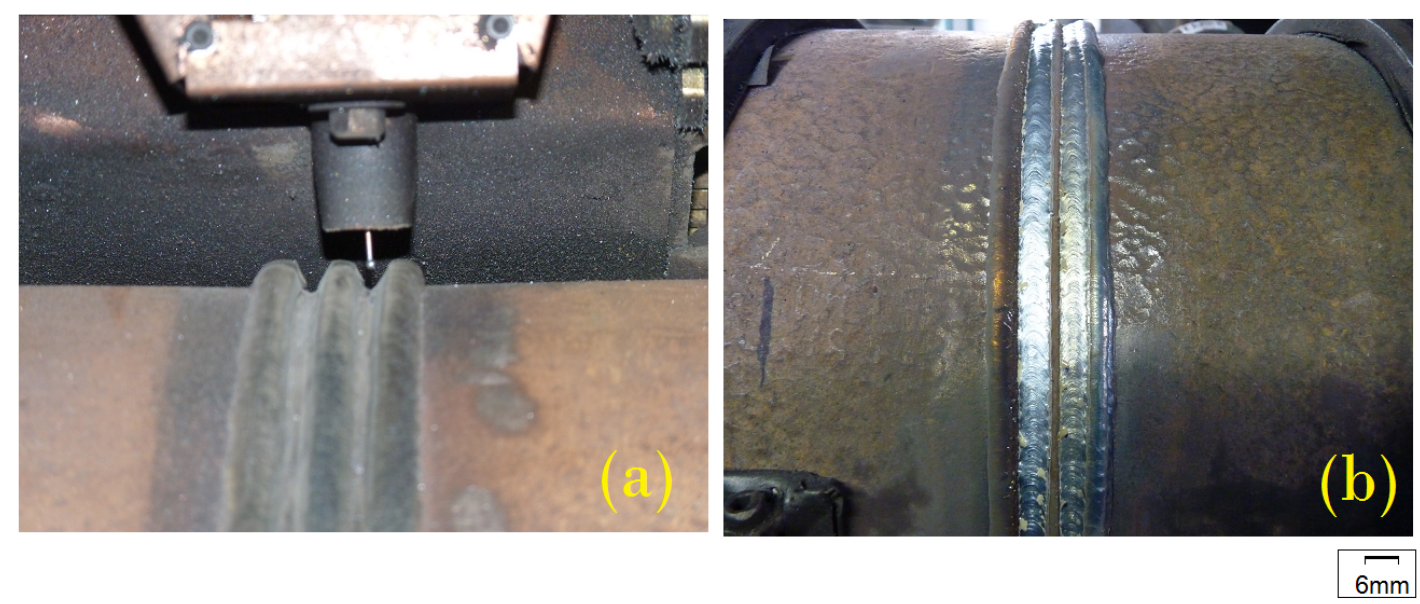

Figura 4.21. (a) Simulação do chanfro com cordões sobrepostos, (b) aspecto visual do cordão depositado na simulação do chanfro para um arame de 1,2 mm de diâmetro

Seguindo a mesma metodologia para fazer a soldagem em passe de raiz no tubo com chanfro estreito, teve-se que variar os parâmetros de corrente, tensão e velocidade de soldagem no deslocamento da tocha, estes parâmetros são mostrados na Tabela 4.9. Como se pode notar nesta tabela a velocidade de soldagem fica maior que na faixa do planejamento, os parâmetros de corrente e tensão deste processo, são relacionados com os utilizados na otimização Desirability mais adiante com a potência de soldagem.

Tabela 4.9. Parâmetros para soldagem orbital com o processo curto-circuito convencional com arame de 1,2 $\mathrm{mm}$ de diâmetro para Passe de raiz

\begin{tabular}{|c|c|c|c|}
\hline \multirow{2}{*}{ Posição } & \multicolumn{3}{|c|}{ Parâmetros do processo de soldagem em meia cana descendente } \\
\cline { 2 - 4 } & Corrente $[\mathrm{A}]$ & Tensão $[\mathrm{V}]$ & Velocidade de Soldagem $[\mathrm{mm} / \mathrm{s}]$ \\
\hline Plana & $138-228$ & $19,0-19,2$ & 5,5 \\
\hline Vertical & $177-225$ & $19,0-19,9$ & 6,0 \\
\hline Sobrecabeça & $173-203$ & $19,3-19,56$ & 7,3 \\
\hline
\end{tabular}

Portanto, a soldagem foi efetuada, considerando todos os parâmetros estabelecidos. A Fig. 4.22 mostra a face do cordão depositado nos tubos, nas posições plana, vertical e sobrecabeça, observando que o cordão teve uma boa geometria sem desvio em umas das paredes laterais do chanfro estreito, como representado na Fig. 3.20. 

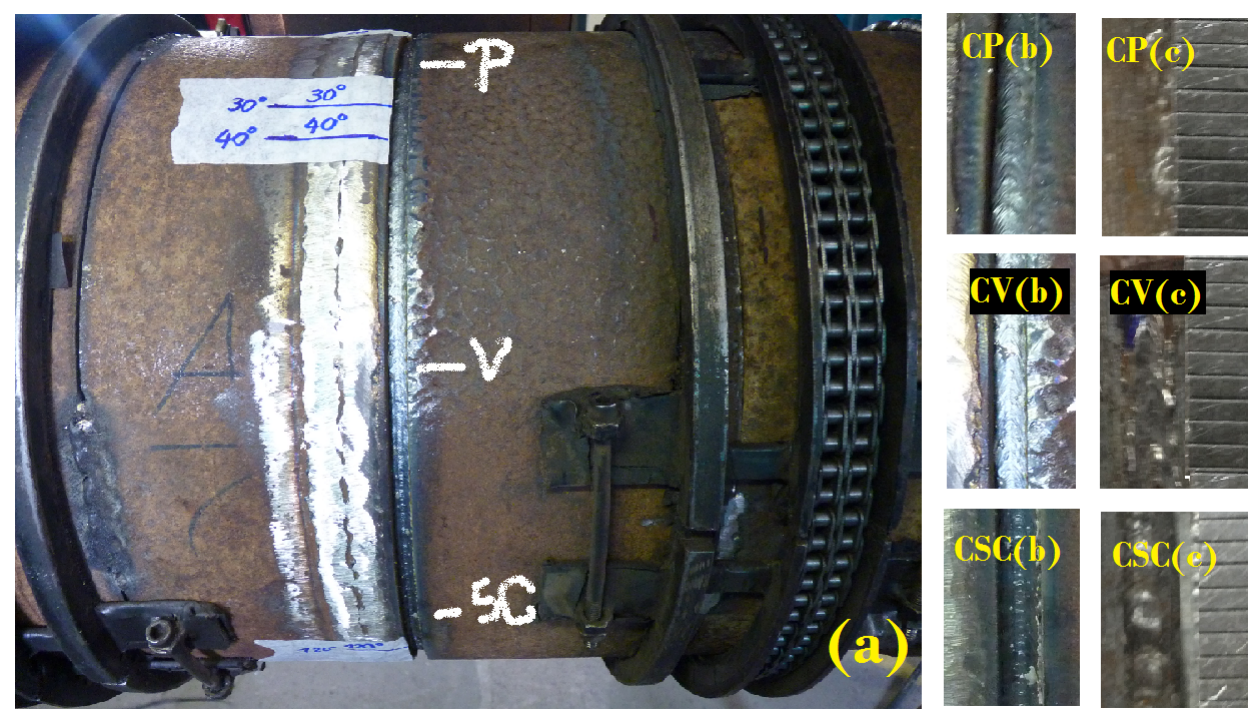

Figura 4.22. (a)Formato da face do cordão obtido no processo de soldagem orbital com arame de 1,2 mm de diâmetro, sem cobre-junta, com espessura de nariz de 2,3 mm, para o processo curto-circuito convencional), (b)face, (c)raiz.
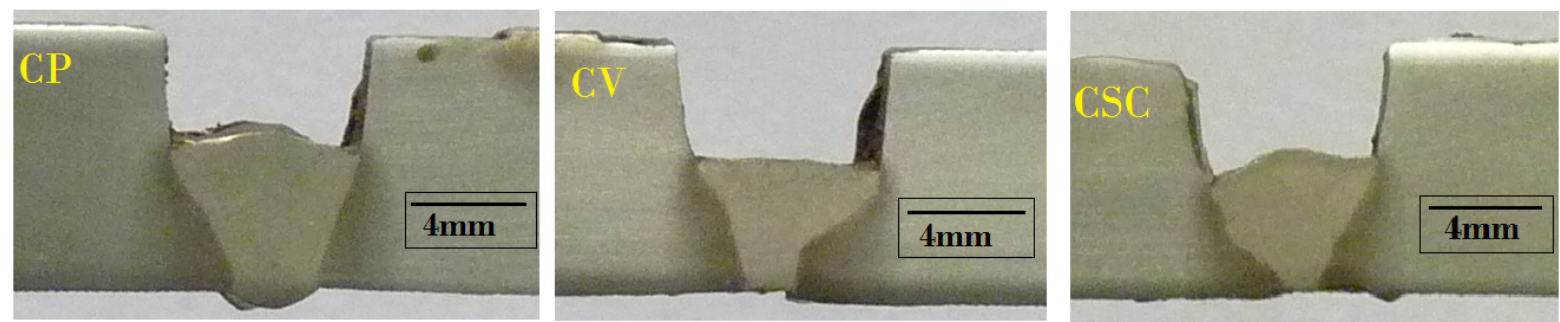

Figura 4.23. Seção transversal da soldagem orbital, com o curto-circuito convencional com arame de 1,2 mm de diâmetro, em pontos onde as posições são plana, vertical e sobrecabeça.

Na Fig. 4.23, pode-se ver primeiramente que a seção transversal do cordão, nestas três posições não apresenta defeitos internos. A face na posição $\mathrm{CP}$ (plana) apresenta um formato convexo, porém, acreditasse que não tenha muita influencia no próximo passe, também conta com reforço na raiz. Em CV(Vertical) apresenta-se um bom formato na face e na raiz mostrando uma penetração completa com um pequeno desalinhamento e sem reforço, finalmente CSC(sobrecabeça) se pode ver que nesta seção se tem um pequeno desalinhamento, sendo assim; nesta posição apresentou uma boa face do cordão e uma penetração completa sem reforço de raiz. 


\subsection{Cálculo da potência de soldagem e discussão dos processos utilizados}

Nesta etapa é apresentada três curvas de análise de sinais, utilizado nas etapas anteriores, a primeira Fig. 4.24 apresenta a curva característica do processo GMAW-CMT da otimização empregada na segunda etapa da metodologia, para fazer o passe de raiz nas três posições críticas em chapas planas com a nariz constante. Na segunda Fig. 4.25 se apresenta uma curva caraterística de um processo de soldagem por curto-circuito convencional, pertence a terceira etapa da metodologia, aplicado no passe de raiz do tubo fazendo a comparação com dois diâmetros de arames (0,9 e 1,2 mm). E na terceira Fig. 4.26 é apresentando um gráfico onde faz a comparação das potências em função do tempo em cada um dos processos de soldagem em passe de raiz. Finalmente é apresentada uma Tabela 4.10 onde mostra os dados calculados para obter a curva de potência dos processos de soldagem anteriores.

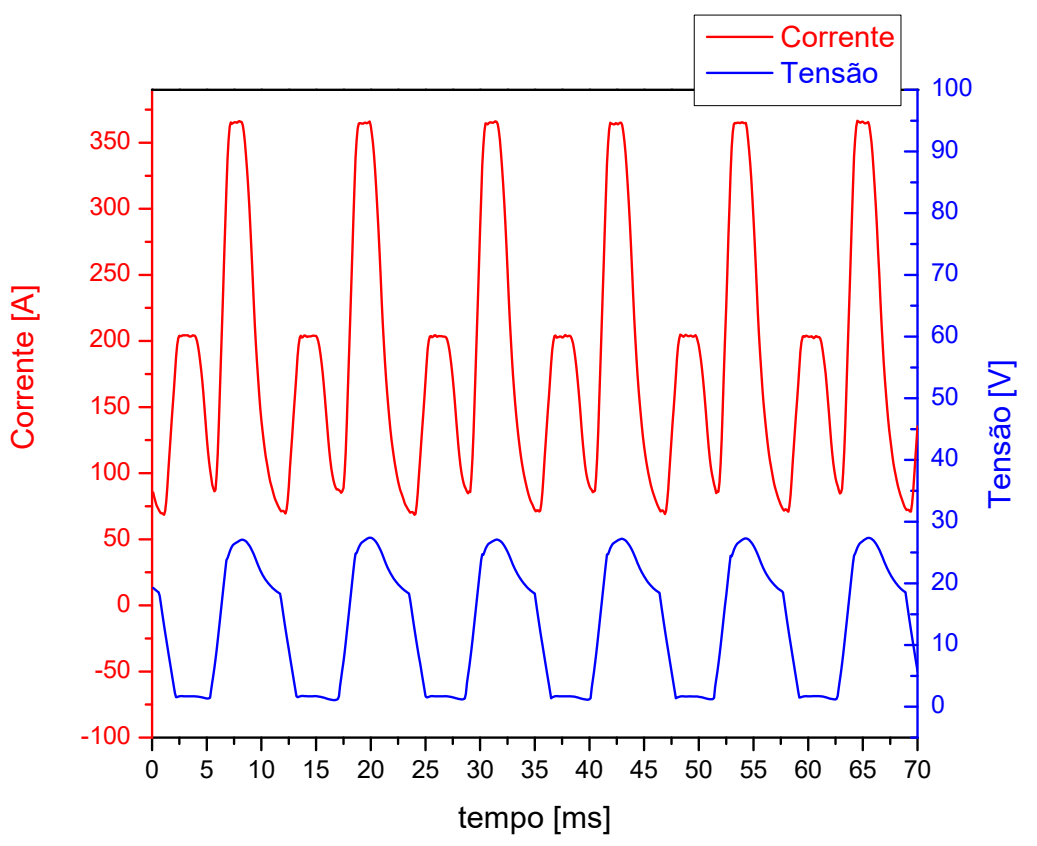

Figura 4.24. Oscilogramas de Corrente, tensão para o modo GMAW-CMT aplicado em chapas planas em passe de raiz.

As curvas de isoconsumo obtidas para o modo GMAW convencional e GMAW-CMT (Fig. 4.24 e Fig. 4.25), dispostas em um mesmo sistema de coordenadas, induzem a atribuição de uma maior potência para a curva do GMAW-CMT. Fazendo uma comparação da tensão média (Um) abrangida pelo GMAW-CMT apresentou uma menor, com respeito do curto-circuito convencional $(\mathrm{CC})$. 


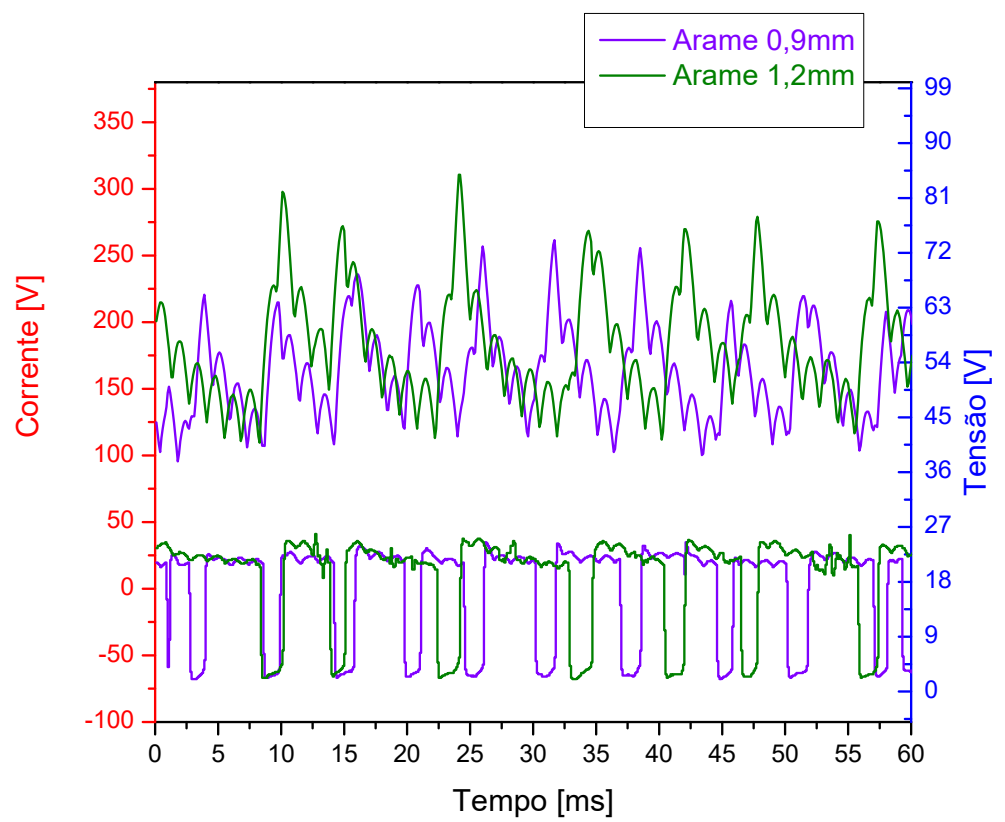

Figura 4.25. Oscilogramas de corrente e voltagem, para o modo curtocircuito convencional, com a comparação de dois tipos de arames em passe de raiz aplicada a união de dois tubos com chanfro estreito sem cobre-junta.

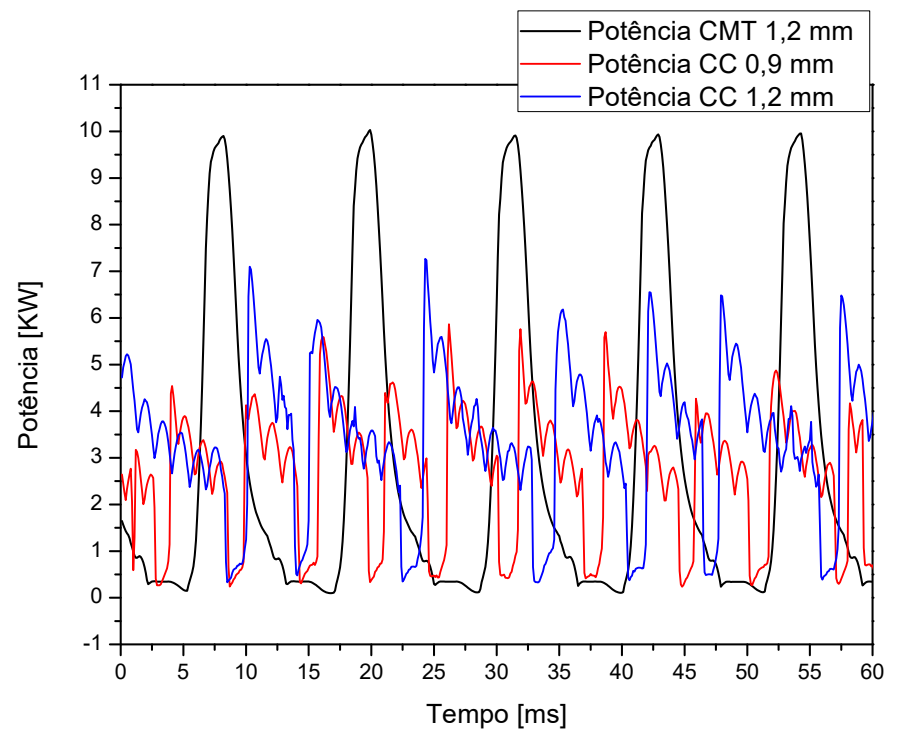

Figura 4.26. Comparação da potência gerada com o processo GMAW-CMT e curto-circuito convencional utilizado em passe de raiz em juntas de chanfro estreito. 
Em uma análise adequada, considerando a devida definição de potência, pode-se perceber que a fundamental razão desta aparente dicotomia está na duração dos níveis altos e baixos da corrente e da tensão. Enquanto no GMAW convencional os picos de corrente de até 327 A e 280 A são praticamente instantâneos, no GMAW-CMT uma corrente de 366 A se mantém constante por 4 ms. Nesta mesma fase a tensão também permanece em patamares baixos, resultando em uma potência baixa. Após esta fase, a tensão cai drasticamente a quase zero e a corrente assume valores próximos a $70 \mathrm{~A}$. Assim, nessa etapa a potência é praticamente zero. Nesta primeira abordagem, poder-se-ia concluir que o CMT conduz a uma baixa potência, já que os pulsos de corrente são mais baixos que no GMAW convencional e também a potência nos curtos-circuitos é muito baixa. Além disso, pode-se adicionar a isto os tempos relativos de curto-circuito e de arco aberto.

Tabela 4.10. Mensuração de valores de Tensão, Corrente (meia e eficaz) e cálculo de Potência

\begin{tabular}{|c|c|c|c|c|c|c|c|}
\hline Processo & $\operatorname{Im}(\mathrm{A})$ & $\mathrm{Um}(\mathrm{V})$ & $\operatorname{Ief}(\mathrm{A})$ & $\mathrm{Uef}(\mathrm{V})$ & $\operatorname{Im} \mathrm{x}$ Um & Ief x Uef & Potência $(\mathrm{W})$ \\
\hline CMT $1,2 \mathrm{~mm}$ & 186,00 & 13,47 & 209,29 & 16,829 & 2505,42 & 3522.14 & 2972,83 \\
\hline CC $0,9 \mathrm{~mm}$ & 165,58 & 17,929 & 169,38 & 19,084 & 2968,68 & 3232,44 & 2786,13 \\
\hline CC $1,2 \mathrm{~mm}$ & 182,99 & 18,77 & 188,02 & 20,23 & 3434,72 & 3803,64 & 3346.89 \\
\hline
\end{tabular}

A Tabela 4.10 mostra os valores calculados, no qual pôde-se constatar a grande diferença entre a potência calculada de maneira correta e as consideradas frequentemente. Assim, podese ver que a potência CMT foi de 2972,83 W, como valor central em comparação nas outras, esta foi a utilizada para ter penetração completa em juntas de chanfro estreito em U, na validação(soldagem orbital) foi utilizado uma fonte convencional com processo curto-circuito com dois arames apresentando uma variação de 6,28\% menor com respeito ao arame de 0,9 mm e ao arame de 1,2 mm apresentou um 12,59\% maior estes com corto circuito convencional. No entanto em termos de potência além de usar processos de soldagem diferentes pode-se concluir que esta variação foi pequena, sendo aceitável para obter penetração completa em juntas de chanfro estreito com soldagem a topo e sem mata-junta. Outra análise que pode-se fazer na terceira etapa com a utilização dos dois arames conclui que com o arame de $0,9 \mathrm{~mm}$ fez um bom preenchimento do chanfro com a vantagem de precisar uma energia menor de soldagem dando boa rentabilidade econômica.

Quanto à qualidade dos cordões de solda, é indubitável o melhor resultado com a utilização por GMAW-CMT, revelando uma aparência boa de face e raiz em quanto à sua aceitabilidade. Já as faces com o GMAW convencional revela uma regular aparência, deixando dúvidas quanto à sua aceitabilidade. Nas duas últimas etapas com os ensaios de macrografia observou-se que os testes não apresentaram defeitos internos. 


\section{CONCLUSÕES E TRABALHOS FUTUROS}

Em base aos resultados apresentados e consideração os objetivos propostos neste trabalho os resultados alcançados: como a construção da estrutura para fazer o procedimento proposto, encontrar os parâmetros para fazer uma soldagem de topo em uma junta de chanfro estreito em chapas planas nas três posições críticas com o processo GMAW-CMT. Assim, sendo validada com êxito a "metodologia de junta de nariz decrescente" por meio de planejamentos experimentais, para logo ser aplicado em uma soldagem orbital, utilizando um processo de soldagem diferente ao inicial (GMAW Convencional).

\subsection{Conclusões}

- Pode-se verificar que para realizar uma soldagem circunferencial é importante primeramente realizar uma parametrização, isto é, realização de testes preliminares nas três posições críticas ou diferenciadas durante esta soldagem: posição plana, vertical no sentido descendente e sobrecabeça, em chapas planas.

- Essa parametrização, verificou, neste trabalho, um mesmo conjunto de parâmetros de soldagem ou corridas, adequados para a soldagem nas três posições estudadas, o que permitirá realizar um planejamento experimental de superficie resposta com a ajuda de análise de resultados por planejamento Central Composto e a teoria Desirability.

- Segundo o planejamento central composto aplicado a "Metodologia de junta de nariz decrescente" pode-se observar quais foram os parâmetros que mais influenciaram no passe de raiz para cada posição estudada e seu respetivo modelo estatístico. Da mesma forma a teoria de Desirability ajudou a fazer uma otimização de parâmetros dos três modelos gerados, para finalmente encontrar um conjunto de parâmetros que consigam fazer uma soldagem de topo sem mata-junta com uma face de nariz constante em chapas planas.

- A execução da espessura de nariz identificado com a "Metodologia de junta de nariz decrescente", foi validada com êxito nas chapas planas, para logo ter uma geometria que finalmente permitiu fazer a soldagem orbital em passe de raiz no tubo em posição 5G. 
- pelos resultados obtidos na etapa da validação, se afirma que a soldagem na posição vertical e sobrecabeça no sentido descendente, são as mais difíceis de soldar em quanto a penetração e estabilidade se refere, devido ao fato do arco elétrico já que faz escorrer a gota metalica depositda entre o metal base, produzindo pouca penetração.

- Nas duas primeiras etapas, foram realizados os teste com um processo de soldagem de curto circuito Derivativo (GMAW-CMT), na validação da terceira etapa utilizou-se uma fonte de soldagem convencional aplicado com êxito. Além de serem dois processos diferentes pode-se conferir que a geometria encontrada e os parâmetros das primeiras etapas foram satisfatórias para a aplicação de soldagem orbital em passe de raiz.

- Quando se implementa uma metodologia para fazer uma soldagem orbital, passando por vários processos de soldagem, uma forma de validação do processo é por meio da potência de soldagem, além de utilizar um modo de transferência de metal frio (GMAW-CMT) a um modo convencional. O calor aportado à peça que contribuiu para a fusão do material, devem ser iguais com uma proximidade um respeito a outra.

- O GMAW-CMT trabalha com valores de tensão de soldagem muito mais baixos, o que justifica o baixo aporte térmico do processo. Além disto, apresentou um envelope mais robusto, com melhor controle da penetração e com perfil da raiz mais uniforme na soldagem de passe de raiz orbital.

- O curto-circuito convencional trabalha em média em um valor mais alto de tensão de soldagem. Quanto à velocidade de alimentação, na progressão descendente requer menores níveis, o que favorece o melhor controle da penetração. Uma raiz produzida por esta versão se apresenta com bom acabamento, tanto na face, como na raiz da junta, sem excesso de reforço no verso da raiz. 


\subsection{Comentários Finais}

- A estrutura para soldagem automatizada em diferentes posições, de chapas planas, foi de muito útil para a realização das soldagens nas três posições: plana, vertical e sobrecabeça, facilitando a fixação e posicionamento das chapas, diminuindo o tempo gasto deste procedimento e garantindo uma maior repetitividade do processo de soldagem.

- O chanfro utilizado partiu de uma necessidade de campo, e apesar da dificuldade na sua fabricação e posteriormente soldagem, proporcionou bons resultados nos dois processos avaliados.

- Para a aplicação desta metodologia, em tubos, um bom alinhamento do diâmetro interno entre as seções dos tubos a serem soldados deve ser bem controlado.

- O cabeçote de soldagem orbital manteve a DBCP sem variação entre as posições plana, vertical e sobre cabeça, permitindo a realização dos testes. Dentre as soluções propostas para a variação da DBCP.

- Durante o ensaio macrográfico dos cordões selecionados, visualmente das três etapas da metodologia, foi uma ferramenta útil, onde não foram encontradas descontinuidades internas (porosidade, inclusões, falta de fusão e trincas). 


\subsection{Propostas de Trabalhos Futuros}

- Utilizar outros tipos de chanfro, como por exemplo, o J que é muito utilizado na industria e fazer uma comparação com o formato em V e U.

- Realizar ensaios mecânicos para avaliação das propriedades mecânicas das juntas soldadas.

- Realizar ensaios destrutivos e não-destrutivos para a qualificação de cordões realizados com os processos GMAW Derivativos, na união de dutos nas progressões ascendente e descendente.

- Realizar estudos acerca do rendimento térmico dos processos GMAW por transferência por curto-circuito convencional e controlados, utilizando técnicas colorimétricas.

- Realizar a soldagem orbital para uma etapa completa a um tubo X80, que são usados nas empresas petrolíferas do Brasil, isto é, passe de raiz (utilizando GTAW), enchimento e acabamento (GMAW Derivativo). 


\section{REFERÊNCIAS BIBLIOGRÁFICAS}

[1] ROMERO, M. F. A solda da tecnologia. TN Petróleo, n. 66, p. 54 - 60, 2009.

[2] PEPE, N. V. D. C. Advances in Gas Metal Arc Welding and Application to Corrosion Resistant Alloy Pipes. 160 p. Tese (Doutorado) - School of Applied Sciences, Cranfield University, 2010.

[3] COSta, T. F. Aplicação de Processos MAG Curto-Circuito Convencional e Controlado na Soldagem de Dutos de Aço Carbono. 197 p. Dissertação (Dissertação em Engenharia Mecânica) — Universidade Federal de Uberlândia, UFU Uberlândia, 2011.

[4] PICKIN, C.; YOUNG, K. Evaluation of cold metal transfer (CMT) process for welding aluminium alloy. Science and Technology of Welding and Joining, v. 11, n. 5, p. 583-585, 2011.

[5] RIBEIRO, J. Análise de Técnicas para a Soldagem TIG Automatizada. 142 p. Dissertação (Dissertação em Engenharia Mecânica) - Universidade Federal de Santa Catarina. UFSC, Florianópolis, 2012.

[6] CAYO, E. H. Modelagem e Controle da Soldagem Orbital Através do Processo GMAW-S. 127 p. Tese (Doutorado em Sistemas Mecatrônicos) — Universidade de Brasília, Departamento de Engenharia Mecânica. UNB, Brasília, 2013.

[7] ABS. A importância da tecnologia de soldagem na construtibilidade de dutos terrestres e marítmos. Revista da Soldagem, 2006.

[8] ANP. Anuário Estatístico Brasileiro do Petróleo, Gás Natural e Biocombustíveis. 2015. Http://www.anp.gov.br/?pg=76798.

[9] FEDELE, R. Desafios da soldagem em tubulações. Revista Metalurgia e Materiais, p. 322, maio 2002.

[10] ROCHA, D. B. Estudo da Soldabilidade do Tubo Api 5 L X80 utilizando os processos de Soldagem: MAG com Transferência controlada e eletrodo Tubular. 218 p. Dissertação (Mestrado 
Engenharia Metalúrgica e de Materiais) - Escola Politécnica da Universidade de São Paulo., São Paulo, 2010.

[11] LAMOND, J.; LEE, K. Y. A cost effective root pass. In: The 4th International scientificprofessional conference. Cost Effective Application of Welding Processes and Welding Related Techniques in Manufacturing of Construction and Products. Slavonski Brod: [s.n.], November $14-16,2007$.

[12] EGHTESAD, M.; BAZARGAN-LARI, Y.; ASSADSANGABI, B. Stability analysis and internal dynamics of mimo gmaw process. In: 17th World Congress The International Federation of Automatic Control IFAC. [S.l.: s.n.], 2008.

[13] HAIDAR, J.; LOWKE, J. Predictions of metal droplet formation in arc welding. Predictions of Metal Droplet Formation in Arc Welding, v. 29, n. 12, p. 2951-2960, 1996.

[14] SCOTTI, A.; PONOMAREV, V. Soldagem MIG/MAG. São Paulo: Artliber Editora Ltda, 2008.

[15] VIEIRA, F. D. Desenvolvimento de Tocha e de Procedimento para a Soldagem MIG/MAG em Chanfro Estreito de Peças Espessas em Aço ao Carbono. Dissertação (Mestrado em Engenharia Mecânica) — Universidade Federal de Santa Catarina. UFSC, Florianópolis, 2012.

[16] GMAW WELDING GUIDE. Lincoln Electric. [S.1.], 2006.

[17] GOMES, E. B. Análise do Comportamento da Soldagem por Curto-Circuito, aplicado ao Processo Eletrodo Tubular através da Metodologia Taguchi. 119 p. Dissertação (Mestre em Engenharia Mecânica) — Universidade Federal de Itajubá, Itajubá, 2006.

[18] SILVA, R. H. G. Soldagem MIG/MAG em Tranferência Metálica por Curto-Circuito Controlado aplicada ao Passe de Raiz. 127 p. Dissertação (Mestre em Engenharia Mecânica) Universidad Federal de Santa Catarina, UFSC, Florianópolis, 2005.

[19] SANTOS, R. P. G. Uma Avaliação Comparativa dos Processos MIG/MAG e Eletrodo Tubular em Termos de Capacidade Produtiva, Geração de Fumos e de Respingos, Usando Consumível para Aço Estrutural. 129 p. Dissertação (de Mestrado) - Universidade Federal de Uberlândia, UFU, Uberlândia, 2010.

[20] JUNIOR, L. P. N. Otimização de um Processo de Solda MIG/MAG para Aplicação na Indústria Automobilística Através da utilização da Técnica do Projeto e Análise de Experimentos. 111 p. Dissertação (Dissertação de Mestrado) — Universidade Federal de Itajubá, Itajubá, 2003.

[21] GIMENES, J. L.; P., R. J. Conceitos de soldagem mig/mag. Infosolda, 2005. 
[22] LIRATZIS, T. Tandem Gas Metal Arc Pipeline Welding. Tese (PhD) - Bedfordshire: Cranfield University, 2007.

[23] HUDSON, M. Welding of X100 Pipeline. Tese (PhD) - Bedfordshire: Cranfield University, 2004.

[24] KVASOV, F. V. Special features of mechanized welding with controlled electrode metal transfer. Weld. J, v. 14, p. 158-161, 2000.

[25] HIMMERLBAUER, K. The CMT-Process, A Revolution in Welding Techonology: Fronius internatinal. [S.l.]. Disponível em: <www.fronius.com. Acesso em: 29/08/2014>.

[26] FRONIUS. CMT: Cold Metal Transfer: Austria. [S.1.], 2005.

[27] SCHORGHUBER, M. Cold-Metal-Transfer Welding Process and Welding Installation. Google Patents, jan. 29 2009. US Patent App. 11/920,516. Disponível em: $<$ https://www.google.com.br/patents/US20090026188>.

[28] MAGALHãES, V. A. N. Simulação Física por Retificação da Soldagem de Dutos com processo GMAW. 151 p. Dissertação (Mestre em Engenharia Mecânica) — Universidade Federal de Uberlândia, Uberlândia, 2012.

[29] ROSAdO, T. M. V. B. Inovação do Processo MIG/MAG - Análise de Produtividade e Emissão de Fumos. Dissertação (Mestre em Engenharia Mecânica) — Universidade Técnica de Lisboa, Lisboa, 2008.

[30] JúNIOR, M. C. Influência Da Transferência Metálica por Curto-Circuito e CMT na Geometria do Cordão e Características da ZTA do dual Phase DP 600. 95 p. Dissertação (Mestre em Engenharia Mecânica) — Universidade Federal do Paraná, UFPR, Curitiba, 2012.

[31] MODEnESI, P. J. Terminologia Usual de Soldagem e Símbolos de Soldagem. Belo Horizonte: Universidade Federal de Minas Gerais, Departamento de Engenharia Metalúrgica e de Materiais, julho de 2008. 10 p.

[32] OKUMURA, T.; TANIGUCHI, C. Engenharia de soldagem e aplicações. Rio de Janeiro: Livros Técnicos e Científicos Editora S.A., p. 461, 1982.

[33] MAN, E. Sif group at the foundation of dutch wind energy. Svetsaren, n. 1, p. 21, 2008.

[34] BADHEKA V. J.; AGRAWAL, S. K. Microstructural investigation of weld metal in lowcarbon steel welded by ng-gmaw. Welding and Cutting, v. 8, n. 4, p. 199-206, 2009.

[35] BRACAREnSE, A. Q. Gas metal arc welding. Artigo Infosolda, 2003. Disponível em: < http://www.infosolda.com.br>. Acesso em: 27/12/2014. 
[36] MALIN, V. Y. The state of the art of narrow gap welding part i. Welding Journal, v. 62, n. 4, p. 22-30, 1983.

[37] MALIN, V. Y. The state of the art of narrow gap welding part ii. Welding Journal, v. 62, n. 6, p. $22-30,1983$.

[38] MODENESI, P. Statistical Modelling of the Narrow Gap Gas Metal Arc Welding Process. Tese (PhD) - Cranfield Institute of Technology, 1990.

[39] TWI. What is narrow gap welding. Disponível em: < www.twi.co.uk/technical knowledge/faqs/process - faqs/faq - what - is - narrow - gap - welding/ >, Acesso em 10/2014. 2014.

[40] D, Y.; S, A. B. Recent developments in high productivity pipeline welding. Journal Brazil Society Mechanichs Science and Eng., v. 26, n. no.1, Rio de Janeiro, Jan./Mar. 2004.

[41] JASNAU, U.; SUMPF, A.; ROSTOCK. Laser hybrid welding with high power fibre laser new chances for use of laser. Acessado em 20 de setembro de 2015. Disponivel em: $<$ http://www.ipgphotonics.com/>.

[42] AURES, J. V. Avaliação de Processos MIG/MAG Derivativos utilizando-Se Simulador de Soldagem de Dutos por Retificação. 173 p. Tese (Doutorado em Sistemas Mecatrônicos) — Universidade de Brasília, Brasília, 2013.

[43] BARBOSA, L. C. A. Modos de transferências semi-automáticas para soldagem de passe de raiz. 2011. Disponível em www.infosolda.com.br. Acesso em maio 2015.

[44] CANTRELL, R. E. Ceramic weld backing evaluation. Welding Journal, v. 61, p. 27-34, march 1982.

[45] SANCHES, A. R. Defeitos em Solda detectáveis através de inspeção visual. 88 p. Monografia (Bacharel em Engenharia Civil) - Centro Universitário Luterano de Manaus, CEULM/ULBRA, 2010.

[46] MODENESI, P. J. Descontinuidade e inspeção em juntas de solda. Belo Horizonte: UFMG, 2001.

[47] DeLGADO, L. C. Estudo e Desenvolvimento do processo TIG Com Alimentação Automática do Arame. Dissertação (Meste Em Engenharia Mecanica) - Universidad Federal de Santa Catarina, UFSC, Florianópolis.

[48] GARCIA, J. A. O. et al. Characterization of titanium welded joints by the orbital gas tungsten arc welding process for aerospace application. Journal of Aerospace Technology and Management., São José dos Campos, v. 2, p. 211-218, 2010. 
[49] MANNION, B.; HEINZMAN, J. Setting up and determining parameters for orbital tube welding. The Fabricator, v. 29, p. 26-30, 1999.

[50] BENWAY, E. A. Advancements in automatic orbital welding expand its use, provide welders with more option. Industrial Maintenance e Plant Operation, v. 61, n. 7, p. 22, 2000.

[51] MANniOn, B. The fundamentals of orbital welding. Gases e Welding Distributor, v. 44, n. 1 , p. $42-44,2000$.

[52] SAGUES, P. Adaptive control techniques advance automatic welding. Welding Journal, v. 89, n. 8 , p. $26-28,2010$.

[53] COOK, G. et al. Statistical process control application to weld process. IEEE Trans. Ind. $A p p l$, v. 33, p. $454-463,1997$.

[54] TIPI, A. D. The study on the drop detachment for automatic pipeline gmaw system: free flight mode. The International Journal of Advance Manufacturing Technology, v. 50, n. 1-4, p. 137-147, 2010.

[55] AWS, Welding Process HandbooK, v.2. [S.1.]: USA, 8th ed.

[56] RAMPAUL, H. Pipe Welding Procedures. [S.l.]: Industrial Press, 2003. ISBN 9780831131418.

[57] LIMAII, E. J. et al. Development of a robot for orbital welding. Industrial Robot Journal, England, v. 32, n. 4, p. 321-325, 2005.

[58] FILHO., F. A. R.; BRACARENSE., A. Q. Development of parallel manipulators for welding robots. in 41 st International Symposium on Robotics and 6th German Conference on Robotics (ROBOTIK), IEEE, Berlin, 2010.

[59] BRIOUX, L. Kentucky power plant turns to orbital pipe welding for expansion. Welding Journal, v. 89, n. 6, p. 58-59, 2010.

[60] LUKKARI, J. Orbital TIG - a great way to join pipes. The ESAB Welding and Cutting Journal, Svetsaren,, v. 60, n. 1, p. 3-6, 2005.

[61] WIDGERY, D. J. Mechanised welding of pipelines. The ESAB Welding and Cutting Journal, Svetsaren, v. 60, n. 1, p. 23-26, 2005.

[62] BISHOP, M. Welding more with less, new technologies take a comprehensive approach to orbital welding operations. The Fabricator, An FMA Publication, 2002. 
[63] FAES., K.; AFSCHRIFT, P. New friction welding process for pipeline girth welds-welding time optimization. The International Journal of Advances Manufacturing Technology, v. 43, n. 9-10, p. 982-992, 2009.

[64] BOOTH, G. S. Laser welding of land pipelines, in proceedings international conference, loughborough,. 2001.

[65] EMMERSON, J. Using mechanized welding on large-diameter pipes. Welding Journal, v. 86, n. 6, p. $66-67,2007$.

[66] KOMIZO, Y. i. Overview of recent welding technology relating to pipeline construction. Transactions of Joining and Welding Research Institute (JWRI), v. 37, n. 1, p. 1-5, 2008.

[67] KEITEL., S.; NEUBERT, J. Laser based girth welding technologies for pipeline construction. The Paton Welding Journal, n. 2, p. 31-36, 2011.

[68] UFSC. Manual de utilização tartÍlope v4. Florianópolis - SC. Disponível em: < http : //www.sps - soldagem.com.br/manuais/Manual artilope $_{V} 4201.02$ - 2010.pdf >. Acesso em: 11 de julho de 2015.

[69] MELLER, R. et al. Desenvolvimento e análise de procedimentos de soldagem orbital mecanizada por intermédio de manipulador robótico para a união de dutos. Congresso Nacional de Soldagem, Natal RN Brasil, p. 0-6, 2011.

[70] MONTGOMERY, D. Design and Analysis of Experiments. Fourth. [S.1.]: John Wiley \& Sons Australia, Limited, 2001. ISBN 9780471020103.

[71] BOX, G. E. P.; DRAPER, N. R. Empirical Model-Building and Response Surfaces. 1. ed. [S.l.]: John Wiley \& Sons, 1987. 650 p.

[72] HARRINGTON, E. C. The desirability function. Industrial Quality Control, n. 21, p. 494498, 1965.

[73] DERRINGER, G.; SUICH, R. Simultaneous optimization of several response variables. Journal of Quality Technology, v. 12, n. 4, p. 214-219, 1980.

[74] GYSEGHEM, E. V. et al. Selection of reversed-phase liquid chromatographic columns with diverse selectivity towards the potential separation of impurities in drugs. Journal of Chromatography, n. 1042, p. 69-80, 2004.

[75] OSBORNE, D. M.; ARMACOST, R. L.; PET-EDWARDS, J. State of the art in multiple response surface methodology. IEEE International Conference on Computacional Cybernetics and Simulation, v. 4, p. 3833-3838, 1997. 
[76] ROSSI, F. Blending response surface methodology and principal components analysis to match a target product. Food Quality and Preference, v. 12, p. 457-465, 2001.

[77] KHURI, A. I.; CONLON, M. Simultaneous optimization of multiple responses represented by polynomial regression functions. Technometrics, v. 23, n. 4, p. 363-375, 1981.

[78] PAIVA, A. P. Metodologia de Superfície de Resposta e Análise de Componentes Principais em otimização de processos de manufatura com múltiplas respostas correlacionadas. Tese (Doutorado) - Universidade Federal de Itajubá,UNIFEI, Itajubá, 2006.

[79] WU, F. C. Optimization of correlated multiple quality characteristics using desirability function. Quality Engineering,, v. 17, n. 1, p. 119-126, 2005.

[80] DUTRA, J. C.; SILVA G, R. H. M. C. Características de fusão e potência de soldagem com a transferência mig - cmt versus mig convencional para alumínio 5183. Soldag. Insp. São Paulo, v. 18, n. 01, p. 012-018, 2013.

[81] CORRÊA, M. A. Diretrizes de projeto e qualificação metrológica de sistemas de medição de grandezas elétricas em processos de soldagem a arco. 012-018 p. Dissertação (dissertação (Mestrado em Engenharia)) — Universidade Federal de Santa Catarina, 1999.

[82] JOSEPH, A. et al. Measurement and calculation of arc power and heat transfer efficiency in pulsed gas metal arc welding. Science and Technology of Welding and Joining, v. 8, n. 6, p. 400-406, 2003.

[83] MURUGAN, N.; PARMAR, R. Effects of mig process parameters on the geometry of the bead in the automatic surfacing of stainless steel. Journal of Materials Processing Technology, 1994.

[84] GUNARAJ, V.; MURUGAN, N. Prediction and comparison of the area of the heat-affected zone for the bead-on-plate and bead-on-joint in submerged arc welding of pipes. Journal of Materials Processing Techonology, p. 246-261, 2000.

[85] RODRIGUES, L. O.; PAIVA, A. P.; COSTA, S. C. Otimização do processo de soldagem com eletrodo tubular através da análise da geometria do cordão de solda. Soldagem Insp. São Paulo, v. 13, n. 2, p. 118-127, 2008.

[86] PAIVA, E. J.; RODRIGUES, L. O.; COSTA, S. C. Otimização do processo de soldagem fcaw usando o erro quadrático médio multivariado. Soldagem Insp. São Paulo, v. 15, n. 1, p. 031-040, 2010.

[87] LOPERA, J. E. P.; ALFARO, S. C. A.; MOTTA, J. M. S. T. Modelagem empírica da transferência goticular projetada em processos de soldagem gmaw. Soldag. Insp. São Paulo, v. 17, n. 4, p. 335-346, 2012. 
[88] XIONG J., Z. G. H. J. e. W. L. Bead geometry prediction for robotic gmaw-based rapid manufacturing through a neural network and a second-order regression analysis. Journal of Intelligent Manufacturing, 2012.

[89] COSTA, T. Soldagem orbital ascendente e descendente com processo mig/mag curtocircuito em dutos em aço carbono de pequeno diâmetro.

[90] TORRES, E. M. M. et al. Parameter optimization in gmaw process with solid and metalcored wires. 22nd International Congress of Mechanical Engineering (COBEM 2013), 2013.

[91] SILVA, A. F.; MARINS, F. A. S. Aplicação da técnica da programação por compromiso(compromise programming) em problemas de projeto e análise de experimentos com múltiplas respostas. Simpósio Brasileiro de Pesquisa Operacional A Pesquisa Operacional na busca de eficiência nos serviços públicos e/ou privados, 2013.

[92] BALfOUR. J. S. SMITH., A. I. A.-S. C. A novel edge feature correlation algorithm for real-time computer vision-based molten weld pool measurements. Welding Journal, v. 85, n. 1, p. 1-8, 2006.

[93] KOLEVA, E.; CHRISTOVA, N.; VELEV, L. Neural network based approach for quality improvement of orbital arc welding joints. 5th IEEE International Conference Intelligent Systems, 2010.

[94] MACHADO, I. G. Dimensionamento de juntas soldadas de filete: Uma revisão crítica. Soldag. insp. São Paulo, v. 16, n. 2, p. 189-201, 2011.

[95] SOUZA, G. et al. Avaliação da proporção de fases em juntas soldadas de tubulações de aço inoxidável duplex mediante aplicação de ensaios não destrutivos. Soldagem e Inspeção. São Paulo, v. 18, n. 02, p. 158-168, 2013.

[96] CORLETT, B.; LUCAS, J. Sensors for narrow-gap welding. IEE PROCEEDINGS-A, v. 138, n. 4, p. $213-222,1991$.

[97] LOPES, A. Arc-Based Sensing in Narrow Groove Pipe Welding. 385 p. Tese (PhD) Cranfield, Bedfordshire, UK: Cranfield University, 206.

[98] EGERLAND, S. Investigations on the influence of joint geometry on the efficiency of gas shielded metal arc welding by using solid state calorimetry. Design Project, Msc Course, Cranfield University, 2009.

[99] SUN, Q. J. et al. Electrode tips geometry and penetrating in narrow gap welding. Science and Technology of Welding and Joining, v. 18, n. 3, p. 198-203, 2013. 
[100] ASSERIN, O. et al. Identification of a heat source model for multipass narrow groove GMA welding process. Weld World, v. 58, n. 161?169, 2014.

[101] R., G.; C.E.; SILVA, R. Desenvolvimento do processo mig/mag com curto-circuito controlado para a soldagem de reparo e união de dutos. 2nd congresso Brasileiro de PeD em Petróleo e Gás. Rio de Janeiro, 2003.

[102] BROERING, C. E. Desenvolvimento de Sistemas para a Automação da Soldagem e Corte Térmico. 127 p. Dissertação (Mestre em Engenharia Mecânica) — Universidade Federal de Santa Catarina, UFSC, Florianópolis, 2005.

[103] PINTO, P. M. A. S. Soldagem Circunferencial de Tubo API 5L X80 empregando Processos manual/semi-automático. 113 p. Dissertação (Mestre em Engenharia Metalúrgica e de Materiais) - Pontifícia Universidade Católica do Rio de Janeiro, Rio de Janeiro, 2006.

[104] BRACARENSE, Q. A.; SORAGI, C.; FELIZARDO, I. Parametrização para soldagem orbital robotizadade tubos com arame tubular. Tecnologia em Metalurgia e Materiales, São Paulo, v. 2, n. 3, p. 6-10, 2006.

[105] FILHO, H. D.; SILVA, R. H. G.; DUTRA, J. C. Comparação do processo MIG/MAG em transferência por curto-circuito com controle de corrente (CCC) com o processo STT na soldagem de passes de raiz em dutos. XXXVIII CONSOLDA - Congresso Nacional de Soldagem , Ouro Preto, MG, 2012.

[106] MENESES, L. Y. H. Modelagem e simulação da transferência metálica no processo GMAW-S em soldagem orbital. 174 p. Dissertação (Mestrado em Sistemas Mecatrônicos) - Universidade de Brasília, Brasília, 2013.

[107] MELLER, R. N. et al. Soldagem orbital mecanizada para a união de tubos na construção de linhas dutoviárias. Rio Oil e Gas Expo and Conference, 2014.

[108] SILVA, L. C. M. D. Soldagem de Tubo de Aço ASTM A106 Gr.B pelo processo a arco elétrico com Arame Tubular com atmosfera protegida (FCAW-G). 96 p. Dissertação (Mestrado em Engenharia Mecânica) — Uuniversidade Federal de Pernambuco, 2009.

[109] MASON, R.; GUNST, R.; HESS, J. Statistical Design and Analysis of Experiments: With Applications to Engineering and Science. Wiley, 2003. (Wiley Series in Probability and Statistics). ISBN 9780471458517. Disponível em: $<$ https://books.google.com.br/books?id=7bOjF4n9RzIC $>$. 
Anexos 


\section{A. ANÁLISE ESTATÍSTICA}

\section{A.1 Avaliação da variância e modelo matemático}

Neste anexo é mostrado o procedimento estatístico para encontrar os modelos matemáticos de penetração aplicando o método de nariz decrescente em chanfro estreito, aplicado a chapas em três posições criticas pré-estabelecidas utilizando o processo de GMAW-CMT. Estes procedimentos estatísticos foram realizado com a ajuda do programa Minitabß. A eliminação de variáveis no modelo matemático foi por meio da técnica de Forward. 
Analise de resultados planejamento composto central por posição

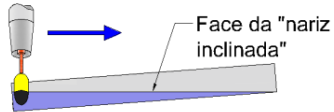

(a) Soldagem Plana

Response Surface Regression: PP versus Va. Vs. I_a

$\begin{array}{lrrrrr}\text { Analysis of Variance } & & & \\ \text { Source } & \text { DF } & \text { Adj SS } & \text { Adj MS } & \text { F-Value } & \text { P-Value } \\ \text { Model } & 9 & 0,343051 & 0,038117 & 2,39 & 0,175 \\ \text { Linear } & 3 & 0,135240 & 0,045080 & 2,82 & 0,146 \\ \quad \text { Va } & 1 & 0,066549 & 0,066549 & 4,17 & 0,097 \\ \text { Vs } & 1 & 0,041252 & 0,041252 & 2,58 & 0,169 \\ \text { I_a } & 1 & 0,027439 & 0,027439 & 1,72 & 0,247 \\ \text { Square } & 3 & 0,054350 & 0,018117 & 1,13 & 0,419 \\ \text { Va*Va } & 1 & 0,003021 & 0,003021 & 0,19 & 0,682 \\ \text { Vs*Vs } & 1 & 0,034854 & 0,034854 & 2,18 & 0,200 \\ \text { I_a*I_a } & 1 & 0,030781 & 0,030781 & 1,93 & 0,224 \\ \text { 2-Way Interaction } & 3 & 0,149850 & 0,049950 & 3,13 & 0,126 \\ \text { Va*Vs } & 1 & 0,000200 & 0,000200 & 0,01 & 0,915 \\ \text { Va*1_a } & 1 & 0,014450 & 0,014450 & 0,90 & 0,385 \\ \text { Vs*l_a } & 1 & 0,135200 & 0,135200 & 8,47 & 0,033 \\ \text { Error } & 5 & 0,079843 & 0,015969 & & \\ \text { Total } & 14 & 0,422893 & & & \end{array}$

Model Summary

$\begin{array}{rrrr}S & R-s q & R-s q(\text { adj) } & R-s q(\text { pred) } \\ 0,126367 & 81,12 \% & 47,14 \% & 0,00 \%\end{array}$

Regression Equation in Uncoded Units

$\mathrm{PP}=-11,4+1,52 \mathrm{Va}+4,00 \mathrm{Vs}-0,05201 \_\mathrm{a}-0,135 \mathrm{Va} * \mathrm{Va}$

$-0,378 \mathrm{Vs} * V s-0,0002321 a * 1 a$

$-0,025 \mathrm{Va} * \mathrm{Vs}-0,00708 \mathrm{Va}{ }^{*} I_{-} \mathrm{a}+0,01733 \mathrm{Vs}{ }^{*} I_{-} \mathrm{a}$

Os termos que que estão realçados em amarelo em primeira instância são escolhidos.

Tendo como critério um $F>1,72$ para que $P$ tenda chegar 0,5 ( $P \leq 0,5)$, se escolheu já que (Vs*la) o F foi alto de 8,47

O valor de F do modelo foi de 2,39 
Fazendo um novo cálculo de análise de variância, pera ter novos $\mathrm{F}$ de cada parâmetro.

\section{Response Surface Regression: PP versus Va. Vs. I_a}

$\begin{array}{lrrrrr}\text { Analysis of Variance } & & & \\ \text { Source } & \text { DF } & \text { Adj SS } & \text { Adj MS } & \text { F-Value } & \text { P-Value } \\ \text { Model } & 6 & 0,32538 & 0,05423 & 4,45 & 0,028 \\ \quad \text { Linear } & 3 & 0,13809 & 0,04603 & 3,78 & 0,059 \\ \quad \text { Va } & 1 & 0,06772 & 0,06772 & 5,56 & 0,046 \\ \text { Vs } & 1 & 0,04147 & 0,04147 & 3,40 & 0,102 \\ \text { l_a } & 1 & 0,02890 & 0,02890 & 2,37 & 0,162 \\ \quad \text { Square } & 2 & 0,05133 & 0,02566 & 2,11 & 0,184 \\ \quad \text { Vs*Vs } & 1 & 0,03828 & 0,03828 & 3,14 & 0,114 \\ \quad \text { I_a*I_a } & 1 & 0,03353 & 0,03353 & 2,75 & 0,136 \\ \quad \text { 2-Way Interaction } & 1 & 0,13520 & 0,13520 & 11,09 & 0,010 \\ \quad \text { Vs*l_a } & 1 & 0,13520 & 0,13520 & 11,09 & 0,010 \\ \text { Error } & 8 & 0,09751 & 0,01219 & & \\ \text { Total } & 14 & 0,42289 & & & \end{array}$

Model Summary

$\begin{array}{rrrr}S & R-s q & R-s q(\text { adj) } & R-s q(p r e d) \\ 0,110405 & 76,94 \% & 59,65 \% & 29,74 \%\end{array}$

Regression Equation in Uncoded Units

$\mathrm{PP}=-6,39+0,1742 \mathrm{Va}+3,19 \mathrm{Vs}-0,0838 \mathrm{l} \mathrm{a}-0,308 \mathrm{Vs} * \mathrm{Vs}$

$-0,0001861 a^{*} 1 a$

$+0,017 \overline{3} 3 \mathrm{Vs}^{\star} 1$

Em comparação com o ajuste anterior (onde descartava Vs*Vs e La*La) em este ajuste Rsq é melhor nesta posição.

No valor de $\mathrm{F}$ do modelo aumento a 4,45 sendo melhor que no ajuste anterior

Equação de regressão:

$P P=$

$-6,39+0,1742 V a+3,19 V s-0,0838 l_{-} a-0,308 V s *$

$V s-0,000186 l_{-} a * l_{-} a+0,01733 V s * l_{-} a \quad$ Ec. 6.1 
Response Surface Regression: Pv versus Va. Vs. I_a

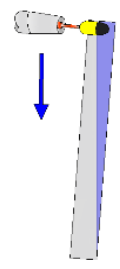

(b) Soldagem Vertical Analysis of Variance Soldagem Vertical

$\begin{array}{lrrrrr}\text { Source } & \text { DF } & \text { Adj SS } & \text { Adj MS } & \text { F-Value } & \text { P-Value } \\ \text { Model } & 9 & 0,480296 & 0,053366 & 3,90 & 0,074 \\ \quad \text { Linear } & 3 & 0,239763 & 0,079921 & 5,84 & 0,043 \\ \quad \text { Va } & 1 & 0,107062 & 0,107062 & 7,82 & 0,038 \\ \text { Vs } & 1 & 0,122208 & 0,122208 & 8,93 & 0,031 \\ \quad \text { I_a } & 1 & 0,010493 & 0,010493 & 0,77 & 0,421 \\ \text { Square } & 3 & 0,054208 & 0,018069 & 1,32 & 0,366 \\ \quad \text { Va*Va } & 1 & 0,000027 & 0,000027 & 0,00 & 0,966 \\ \quad \text { Vs*Vs } & 1 & 0,031495 & 0,031495 & 2,30 & 0,190 \\ \text { I_a*I_a } & 1 & 0,003538 & 0,003538 & 0,26 & 0,633 \\ \text { 2-Way Interaction } & 3 & 0,187800 & 0,062600 & 4,57 & 0,068 \\ \quad \text { Va*Vs } & 1 & 0,057800 & 0,057800 & 4,22 & 0,095 \\ \quad \text { Va*I_a } & 1 & 0,125000 & 0,125000 & 9,13 & 0,029 \\ \quad \text { Vs*I_a } & 1 & 0,005000 & 0,005000 & 0,37 & 0,572 \\ \text { Error } & 5 & 0,068437 & 0,013687 & & \\ \text { Total } & 14 & 0,548733 & & & \end{array}$

Model Summary

$\begin{array}{rrrr}S & R-s q & R-s q(\text { adj) } & R-s q(\text { pred) } \\ 0,116994 & 87,53 \% & 65,08 \% & 0,00 \%\end{array}$

Regression Equation in Uncoded Units

$\mathrm{PV}=1,2-2,02 \mathrm{Va}+1,87 \mathrm{Vs}-0,11231 \mathrm{a}+0,013 \mathrm{Va} * \mathrm{Va}$

$-0,359 \mathrm{Vs} * V s-0,0000791 \mathrm{I} a * 1$ a

$+0,425 \mathrm{Va} * \mathrm{Vs}+0,020 \overline{8} 3 \mathrm{Va}{ }^{*}{ }_{-}{ }_{\mathrm{a}}+0,00333 \mathrm{Vs}{ }^{*}{ }_{-} \mathrm{a}$

Fits and Diagnostics for Unusual Observations

\begin{tabular}{rrrrr} 
Obs & Pv & Fit & \multicolumn{3}{c}{ Resid } \\
15 & 2,300 & 2,298 & 0,002 & $0,25 \quad$ X
\end{tabular}

X Unusual X 
Response Surface Regression: Pv versus Va. Vs. I_a

\begin{tabular}{|c|c|c|c|c|c|}
\hline Source & $\mathrm{DF}$ & Adj $S S$ & Adj MS & F-Value & P-Value \\
\hline Mode 1 & 6 & 0,46852 & 0,07809 & 7,79 & 0,005 \\
\hline Linear & 3 & 0,24006 & 0,08002 & 7,98 & 0,009 \\
\hline $\mathrm{Va}$ & 1 & 0,10736 & 0,10736 & 10,71 & 0,011 \\
\hline Vs & 1 & 0,12221 & 0,12221 & 12,19 & 0,008 \\
\hline 1 a & 1 & 0,01049 & 0,01049 & 1,05 & 0,336 \\
\hline Squāre & 1 & 0,04743 & 0,04743 & 4,73 & 0,061 \\
\hline$V s * V s$ & 1 & 0,04743 & 0,04743 & 4,73 & 0,061 \\
\hline 2-Way Interaction & 2 & 0,18280 & 0,09140 & 9,12 & 0,009 \\
\hline $\mathrm{Va} * \mathrm{Vs}$ & 1 & 0,05780 & 0,05780 & 5,76 & 0,043 \\
\hline$V a{ }^{*}{ }_{1} a$ & 1 & 0,12500 & 0,12500 & 12,47 & 0,008 \\
\hline Error & 8 & 0,08021 & 0,01003 & & \\
\hline Total & 14 & 0,54873 & & & \\
\hline
\end{tabular}

Model Summary
0,100133
$R-s q$
$85,38 \%$
$R-s q(\operatorname{adj})$
$\mathrm{R}-\mathrm{sq}$ (pred)
$74,42 \%$
$45,28 \%$

Regression Equation in Uncoded Units

$\begin{array}{rr}P v=2,03-1,906 V a+1,42 V s-0,0957 l_{-} a-0,314 V s * \\ V s+0,425 V a * V s+0,02083 V a * l_{-} a & \text { Ec.6.2 }\end{array}$

Nesta regressão o $\mathrm{F}$ do modelo é $\mathrm{F}=7,79>\mathrm{F}=3,90$ (anterior) 


\section{Posição Sobrecabeça}

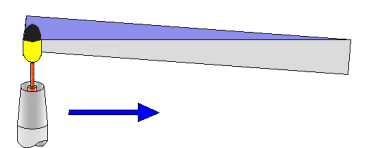

(c) Soldagem

Sobrecabeça

\section{Response Surface Regression: Psc versus Va. Vs. I_a}

$\begin{array}{lrrrrr}\text { Analysis of Variance } & & & \\ \text { Source } & \text { DF } & \text { Adj SS } & \text { Adj MS } & \text { F-Value } & \text { P-Value } \\ \text { Model } & 9 & 0,819178 & 0,091020 & 4,97 & 0,046 \\ \quad \text { Linear } & 3 & 0,241602 & 0,080534 & 4,40 & 0,072 \\ \quad \text { Va } & 1 & 0,074932 & 0,074932 & 4,09 & 0,099 \\ \text { Vs } & 1 & 0,162220 & 0,162220 & 8,86 & 0,031 \\ \text { I_a } & 1 & 0,004450 & 0,004450 & 0,24 & 0,643 \\ \text { Square } & 3 & 0,081293 & 0,027098 & 1,48 & 0,327 \\ \text { Va*Va } & 1 & 0,019111 & 0,019111 & 1,04 & 0,354 \\ \text { Vs*Vs } & 1 & 0,012944 & 0,012944 & 0,71 & 0,439 \\ \text { I_a*1_a } & 1 & 0,074344 & 0,074344 & 4,06 & 0,100 \\ \text { 2-Way Interaction } & 3 & 0,484300 & 0,161433 & 8,82 & 0,019 \\ \text { Va*Vs } & 1 & 0,033800 & 0,033800 & 1,85 & 0,232 \\ \text { Va*1_a } & 1 & 0,432450 & 0,432450 & 23,62 & 0,005 \\ \text { Vs*1_a } & 1 & 0,018050 & 0,018050 & 0,99 & 0,366 \\ \text { Error } & 5 & 0,091555 & 0,018311 & & \\ \text { Total } & 14 & 0,910733 & & & \end{array}$

Model Summary

$\begin{array}{rrrr}\mathrm{S} & \mathrm{R}-\mathrm{sq} & \mathrm{R}-\mathrm{sq}(\mathrm{adj}) & \mathrm{R}-\mathrm{sq}(\mathrm{pred}) \\ 0,135318 & 89,95 \% & 71,85 \% & 5,95 \%\end{array}$

Regression Equation in Uncoded Units

$\mathrm{PSC}=-2,5+1,63 \mathrm{Va}+0,61 \mathrm{Vs}+0,14421_{-} \mathrm{a}-0,340 \mathrm{Va} * \mathrm{Va}$

- $0,230 \mathrm{Vs} * V s-0,0003611 a * 1 a$

$+0,325 \mathrm{Va} * \mathrm{Vs}-0,03 \overline{8} 75 \overline{\mathrm{V}}{ }^{\star}{ }^{*}{ }_{-} \mathrm{a}+0,00633 \mathrm{Vs}{ }^{*}{ }_{-} \mathrm{a}$ 
Response Surface Regression: Psc versus Va. Vs. I_a

$\begin{array}{lrrrrr}\text { Analysis of Variance } & & & \\ \text { Source } & \text { DF } & \text { Adj SS } & \text { Adj MS } & \text { F-Value } & \text { P-Value } \\ \text { Model } & 5 & 0,747026 & 0,149405 & 8,21 & 0,004 \\ \quad \text { Linear } & 3 & 0,249523 & 0,083174 & 4,57 & 0,033 \\ \quad \text { Va } & 1 & 0,078031 & 0,078031 & 4,29 & 0,068 \\ \quad \text { Vs } & 1 & 0,167042 & 0,167042 & 9,18 & 0,014 \\ \quad \text { I_a } & 1 & 0,004450 & 0,004450 & 0,24 & 0,633 \\ \quad \text { Square } & 1 & 0,060990 & 0,060990 & 3,35 & 0,100 \\ \quad \text { I_a*l_a } & 1 & 0,060990 & 0,060990 & 3,35 & 0,100 \\ \quad \text { 2-Way Interaction } & 1 & 0,432450 & 0,432450 & 23,77 & 0,001 \\ \quad \text { Va*l_a } & 1 & 0,432450 & 0,432450 & 23,77 & 0,001 \\ \text { Error } & 9 & 0,163708 & 0,018190 & & \\ \text { Total } & 14 & 0,910733 & & & \end{array}$

Model Summary

$\begin{array}{rrrr}S & R-s q & R-s q(\text { adj }) & R-s q(\text { pred) } \\ 0,134869 & 82,02 \% & 72,04 \% & 52,70 \%\end{array}$

Regression Equation in Uncoded Units

$P s c=$

$2,686+0,1870 V a-0,2312 V s+0,1759 l_{-} a-0,000229 l_{-} a *$ $l_{-} a-0,03875 \mathrm{Va} * l_{-} a$

Ec. 6.3

Nesta regressão o $\mathrm{F}$ do modelo é $\mathrm{F}=8,21>\mathrm{F}=4,97$ (anterior) 